Prepared in cooperation with the U.S. Fish and Wildlife Service

Characterization of Water-Resource Threats and Needs for U.S. Fish and Wildlife Service National Wildlife Refuges in the Legacy Mountain-Prairie Region, 2020

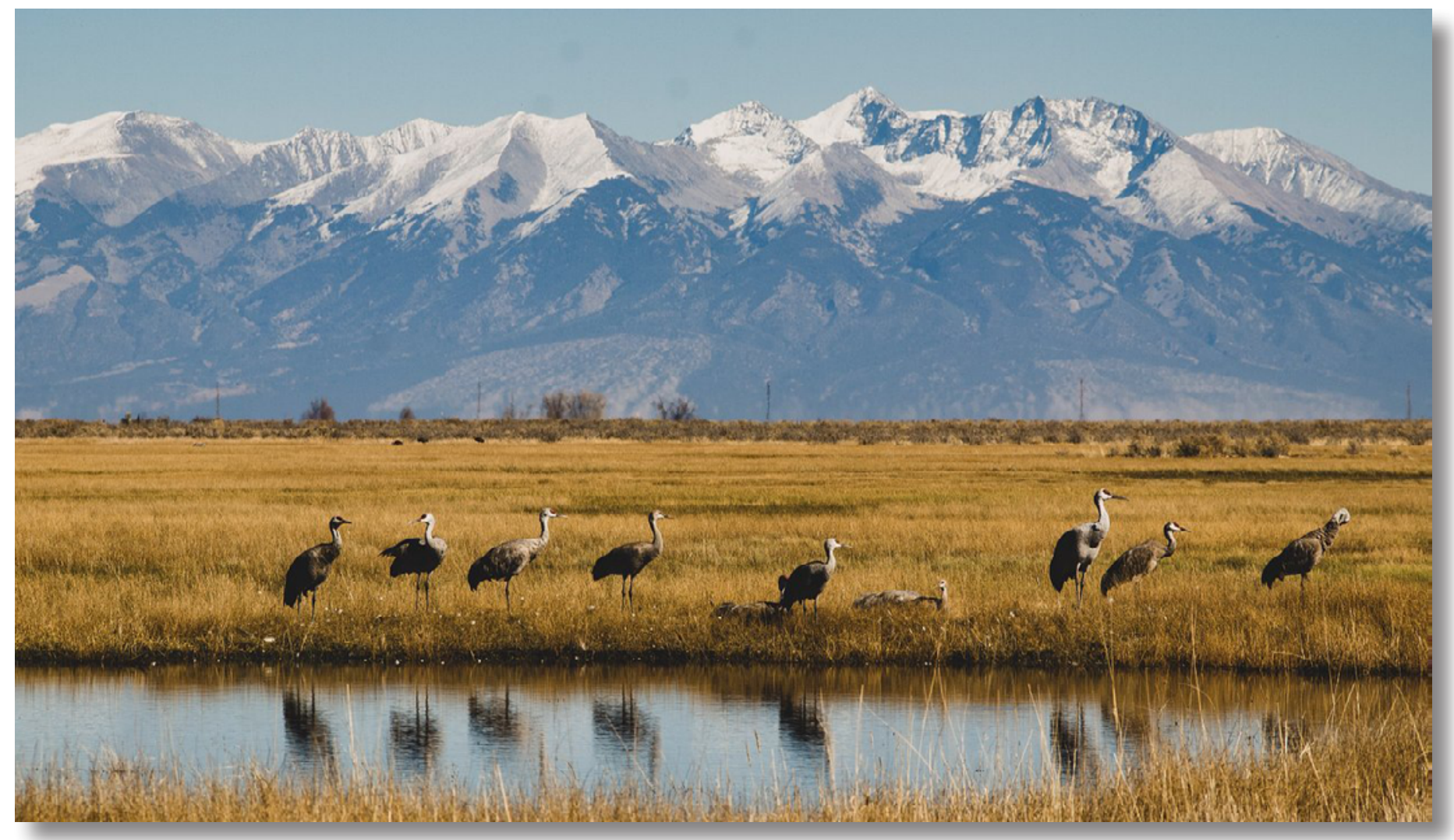

Open-File Report 2021-1007 
Covers. (Front) Grus canadensis (sandhill crane) at Monte Vista National Wildlife Refuge in southern Colorado with Sangre de Christo Mountains in the background [Photograph by U.S. Fish and Wildlife Service]. (Back) Sunrise at Rocky Mountain Arsenal National Wildlife Refuge in Denver, Colorado [Photograph by Peter Ismert, November 20, 2016]. Construction of sluice gate (left) and headgate (right) for the New Ditch diversion at Alamosa National Wildlife Refuge in southern Colorado [Photograph by Gabriel Martinez, U.S. Fish and Wildlife Service, November 2020]. Chen caerulescens (snow goose) at Quivira National Wildlife Refuge in central Kansas where hundreds of thousands of ducks and geese stop annually [Photograph by U.S. Fish and Wildlife Service]. Water from Lake Darling, located near Minot, North Dakota, released through Lake Darling Dam flooded the Souris River [Photograph by Joel Galloway, U.S. Geological Survey, June 2011]. 


\section{Characterization of Water-Resource Threats and Needs for U.S. Fish and Wildlife Service National Wildlife Refuges in the Legacy Mountain-Prairie Region, 2020}

By Nancy J. Bauch, Michael S. Kohn, and Brian S. Caruso

Prepared in cooperation with the U.S. Fish and Wildlife Service

Open-File Report 2021-1007 


\section{U.S. Geological Survey, Reston, Virginia: 2021}

For more information on the USGS - the Federal source for science about the Earth, its natural and living resources, natural hazards, and the environment—visit https://www.usgs.gov or call 1-888-ASK-USGS.

For an overview of USGS information products, including maps, imagery, and publications, visit https://store.usgs.gov/.

Any use of trade, firm, or product names is for descriptive purposes only and does not imply endorsement by the U.S. Government.

Although this information product, for the most part, is in the public domain, it also may contain copyrighted materials as noted in the text. Permission to reproduce copyrighted items must be secured from the copyright owner.

Suggested citation:

Bauch, N.J., Kohn, M.S., and Caruso, B.S., 2021, Characterization of water-resource threats and needs for U.S. Fish and Wildlife Service National Wildlife Refuges in the Legacy Mountain-Prairie Region, 2020: U.S. Geological Survey Open-File Report 2021-1007, 46 p., https://doi.org/10.3133/ofr20211007.

ISSN 2331-1258 (online) 


\section{Acknowledgments}

The authors thank the staff of the U.S. Fish and Wildlife Service Legacy Mountain-Prairie Region National Wildlife Refuges and the Division of Water Resources for their assistance in the compilation and quality assurance of the water-resource threats and needs. Alisa Mast (U.S. Geological Survey) and Mike Higgins (U.S. Fish and Wildlife Service) provided technical reviews of the manuscript. Will McDermott of the U.S. Geological Survey compiled early drafts of maps used in this report. 



\section{Contents}

Acknowledgments ……...................................................................................................................

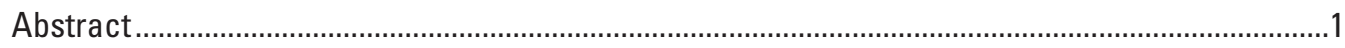

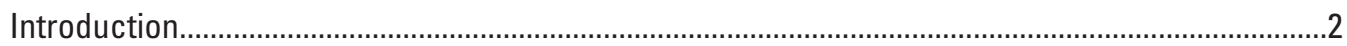

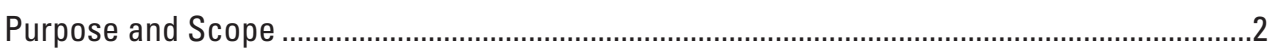

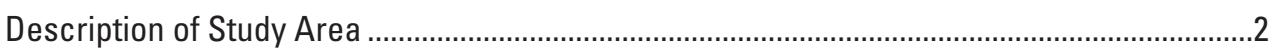

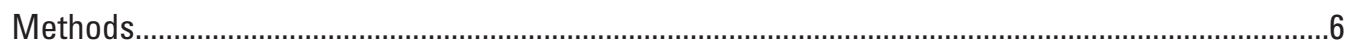

Data Compilation and Quality Assurance .............................................................................

Statistical, Graphical, and Mapping Techniques.......................................................................

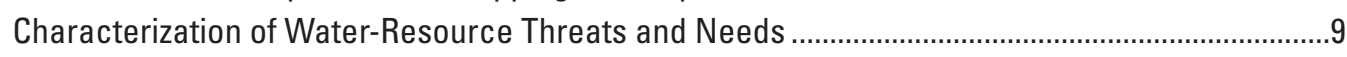

Water-Resource Threats ................................................................................................

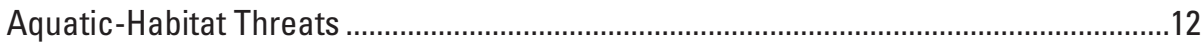

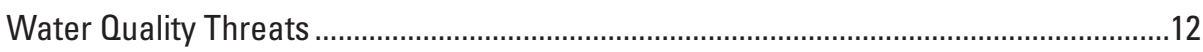

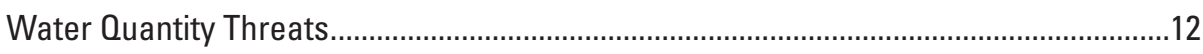

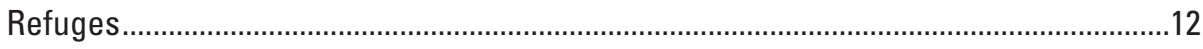

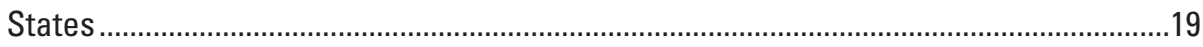

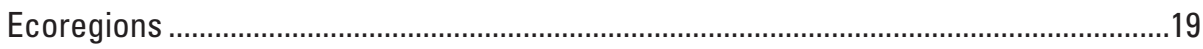

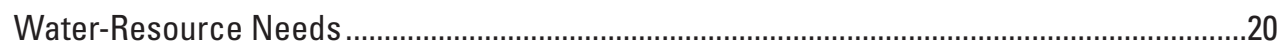

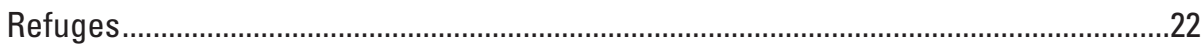

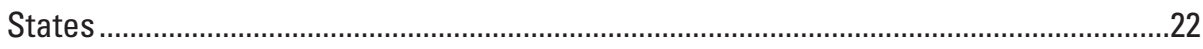

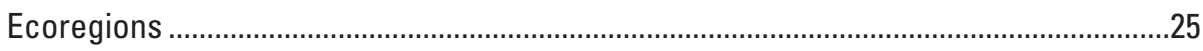

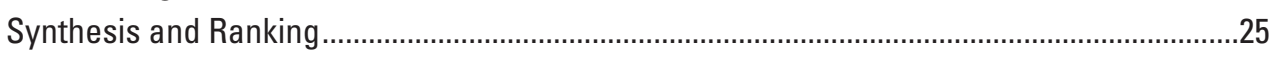

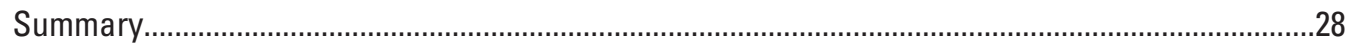

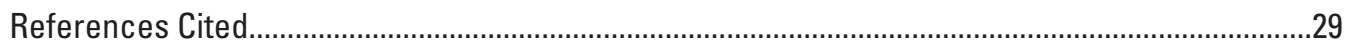

Appendix 1. Table Listing U.S. Wildlife Fish and Wildlife Service Refuges in the Legacy

Mountain-Prairie Region and Maps Showing Severity and Priority Ratings for the

Most Common Water-Resource Threat Types and Causes and Water-Resource

Need Types.................................................................................................................................

\section{Figures}

1. Maps showing $A$, locations of U.S. Fish and Wildlife Service National Wildlife Refuges in the Legacy Mountain-Prairie Region and $B$, refuge locations in North Dakota

2. Map showing U.S. Environmental Protection Agency Level III Ecoregion boundaries and locations of U.S. Fish and Wildlife Service National Wildlife Refuges in the Legacy Mountain-Prairie Region

3. Graphs showing $A$, the 10 most common water-resource threat types; $B$, the 10 most common high-severity water-resource threat types; $C$, the 11 most common causes of water-resource threats; and $D$, the 11 most common causes of high-severity water-resource threats on U.S. Fish and Wildlife Service National Wildlife Refuges in the Legacy Mountain-Prairie Region and the number of refuges where each threat type and cause were reported... 
4. Graphs showing $A$, aquatic-habitat threat types; $B$, high-severity aquatic-habitat threat types; $C$, the most common causes of aquatic-habitat threats; and $D$, the most common causes of high-severity aquatic-habitat threats on U.S. Fish and Wildlife Service National Wildlife Refuges in the Legacy Mountain-Prairie Region and the number of refuges where each aquatic-habitat threat type and cause were reported

5. Graphs showing $A$, the 10 most common water-quality threat types; $B$, the 10 most common high-severity water-quality threat types; $C$, the 10 most common causes of water-quality threats; and $D$, the 10 most common causes of high-severity water-quality threats on U.S. Fish and Wildlife Service National Wildlife Refuges in the Legacy Mountain-Prairie Region and the number of refuges where each water-quality threat type and cause were reported

6. Graphs showing $A$, water-quantity threat types; $B$, high-severity water-quantity threat types; $C$, the 10 most common causes of water-quantity threats; and $D$, the 11 most common causes of high-severity water-quantity threats on U.S. Fish and Wildlife Service National Wildlife Refuges in the Legacy Mountain-Prairie Region and the number of refuges where each water-quantity threat type and cause were reported

7. Graphs showing National Wildlife Refuges in the U.S. Fish and Wildlife Service Legacy Mountain-Prairie Region with the most $A$, water-resource threat types; $B$, high-severity water-resource threat types; $C$, causes of water-resource threats; and $D$, causes of high-severity water-resource threats

8. Map showing count of water-resource threat types on National Wildlife Refuges in the U.S. Fish and Wildlife Service Legacy Mountain-Prairie Region

9. Map showing count of high-severity water-resource threat types on National Wildlife Refuges in the U.S. Fish and Wildlife Service Legacy Mountain-Prairie Region.

10. Graphs showing $A$, the most common water-resource need types; and $B$, the most common high-priority water-resource need types on U.S. Fish and Wildlife Service National Wildlife Refuges in the Legacy Mountain-Prairie Region and the number of refuges where each need type was reported...

11. Graphs showing National Wildlife Refuges in the U.S. Fish and Wildlife Service Legacy Mountain-Prairie Region with $A, 15$ or more water-resource need types and $B, 8$ or more unique high-priority water-resource need types

12. Map showing count of water-resource need types on National Wildlife Refuges in the U.S. Fish and Wildlife Service Legacy Mountain-Prairie Region (EPA, U.S. Environmental Protection Agency).

13. Map showing count of unique water-resource need types with a high-priority rating on National Wildlife Refuges in the U.S. Fish and Wildlife Service Legacy Mountain-Prairie Region

14. Graphs showing National Wildlife Refuges in the U.S. Fish and Wildlife Service Legacy Mountain-Prairie Region with the greatest ranking values for $A$, high-severity water-resource threat types; $B$, high-priority water-resource needs; and $C$, overall ranking values.

\section{Tables}

1. Information for water-resource threats available in the U.S. Fish and Wildlife Environmental Conservation Online System Water Resource Inventory and Assessment application . 
2. Information for water-resource needs available in the U.S. Fish and Wildlife Environmental Conservation Online System Water Resource Inventory and Assessment application

3. Example threats and needs data in the U.S. Fish and Wildlife Service Environmental Conservation Online System Water Resource Inventory and Assessment application for Bear River Migratory Bird Refuge in Utah.

4. Summary of threat and needs types for U.S. Fish and Wildlife National Wildlife Refuges in the Legacy Mountain-Prairie Region for all unique occurrences and occurrences handled by the FWS alone, number of refuges, and number of unique causes

5. The three most common water-resource threat types on U.S. Fish and Wildlife National Wildlife Refuges in the Legacy Mountain-Prairie Region and the most common causes of each threat type.

6. The three most common high-severity water-resource threat types on U.S. Fish and Wildlife National Wildlife Refuges in the Legacy Mountain-Prairie Region and the most common causes of each high-severity threat type

7. States in the U.S. Fish and Wildlife Service Legacy Mountain-Prairie Region and the number of water-resource threat types and causes and percentage of high-severity threat types and causes at National Wildlife Refuges in each state

8. Characteristics of U.S. Environmental Protection Agency Northern Glaciated Plains, Northwestern Glaciated Plains, and Northwestern Great Plains Level III Ecoregions, and the most common water-resource threat types on U.S. Fish and Wildlife National Wildlife Refuges in each of the three ecoregions within the Legacy Mountain-Prairie Region

9. States in the U.S. Fish and Wildlife Service Legacy Mountain-Prairie Region and the number of water-resource need types and percentage of high-priority need types at National Wildlife Refuges in each state.

10. The most common water-resource need types on U.S. Fish and Wildlife National Wildlife Refuges in the U.S. Environmental Protection Agency Northern Glaciated Plains, Northwestern Glaciated Plains, and Northwestern Great Plains Level III Ecoregions within the Legacy Mountain-Prairie Region

\section{Conversion Factors}

U.S. customary units to International System of Units

\begin{tabular}{|c|c|c|}
\hline Multiply & By & To obtain \\
\hline \multicolumn{3}{|c|}{ Area } \\
\hline acre & 0.4047 & hectare (ha) \\
\hline mile (mi) & 1.609 & Kilometer (km) \\
\hline
\end{tabular}

\section{Datum}

Horizontal coordinate information is referenced to the North American Datum of 1983 (NAD 83). 
viii

\section{Abbreviations}

$\begin{array}{ll}\text { DWR } & \text { Division of Water Resources } \\ \text { ECOS } & \text { Environmental Conservation Online System } \\ \text { EPA } & \text { U.S. Environmental Protection Agency } \\ \text { FWS } & \text { U.S. Fish and Wildlife Service } \\ \text { LMPR } & \text { Legacy Mountain-Prairie Region } \\ \text { MBR } & \text { Migratory Bird Refuge } \\ \text { NWR } & \text { National Wildlife Refuge } \\ \text { TDS } & \text { total dissolved solids } \\ \text { USGS } & \text { U.S. Geological Survey } \\ \text { WRIA } & \text { Water Resource Inventory and Assessment }\end{array}$




\title{
Characterization of Water-Resource Threats and Needs for U.S. Fish and Wildlife Service National Wildlife Refuges in the Legacy Mountain-Prairie Region, 2020
}

\author{
By Nancy J. Bauch,' Michael S. Kohn, ${ }^{1}$ and Brian S. Caruso²
}

\section{Abstract}

The U.S. Geological Survey, in cooperation with the U.S. Fish and Wildlife Service (FWS), began a study in 2019 to complete the compilation and quality assurance of water-resource threats and needs data for the 117 National Wildlife Refuges (NWRs) in the FWS Legacy Mountain-Prairie Region (LMPR) and to characterize the water-resource threats and needs of each refuge and of the LMPR itself. The LMPR encompasses the states of Colorado, Kansas, Montana, Nebraska, North Dakota, South Dakota, Utah, and Wyoming. This report includes the compilation and quality assurance of current (April 2020) waterresource threats and needs data for the refuges in the LMPR and a statistical, graphical, and spatial characterization, including the ranking and prioritization of threat types, threat causes, and needs by the number of occurrences in the LMPR as a whole and by refuges, states, and select U.S. Environmental Protection Agency Level III Ecoregions.

A total of 540 unique threat occurrences were identified for 109 refuges in the LMPR. No threats were identified for eight refuges. About 43 percent of the threat occurrences, for 59 refuges, had a high-severity threat rating. Of the 10 most common threat types, 8 were also among the most common high-severity threat types. Water-resource threats had 72 different causes. About 83 percent of the overall common causes for threats and for high-severity threats were the same. The most common threat types overall and the most common highseverity threat types were compromised water management capability, habitat shifting/alteration, and altered flow regimes. The 20 water-resource threat types for Long Lake NWR were the most for refuges in the LMPR. Other refuges with the greatest number of threat types included Marais des Cygnes NWR (18) and Arapaho and Lee Metcalf NWRs (16 each). About 54 percent of refuges with threats had high-severity threats. Arapaho and Quivira NWRs each had 10 high-severity threat types, the maximum number of high-severity threat types for LMPR refuges.

\footnotetext{
${ }^{1}$ U.S. Geological Survey.

2 U.S. Fish and Wildlife Service.
}

A total of 637 unique need occurrences were identified for 114 refuges. No needs were reported for three refuges. The most common need type, a Water Resource Inventory and Assessment, was reported for 78 refuges. Two of the most common need types, repair and replace water management infrastructure and water supply/quantity monitoring, were the most common high-priority need types. Bear River Migratory Bird Refuge had the most (39) unique water-resource need types for refuges in the LMPR. Other refuges with the greatest number of need types were Baca (38), Alamosa (36), and Monte Vista (36) NWRs. The most high-priority need types for a refuge was 23, at Monte Vista NWR. Alamosa (22), Baca (22), and Lake Andes (19) NWRs were also among the top 4 refuges with the greatest number of high-priority need types.

An overall ranking scheme was developed to identify refuges that have the highest-ranking priority for conservation efforts to fulfill refuges' statutory purposes. The count of occurrences of high-severity threats and high-priority needs were summed to determine the overall ranking value for a refuge. The 10 refuges with the highest overall ranking values, in order of ranking from higher to lower, were Alamosa, Baca, and Monte Vista NWRs (tied for highest); Lake Andes NWR, Ouray and Quivira NWRs, Bear River Migratory Bird Refuge and Flint Hills NWR, Cokeville Meadows NWR, and Arapaho NWR.

About 33 percent of overall threat occurrences were reported as under the control of the FWS to mitigate, as were 37 percent of all threat occurrences with a high-severity rating. The most common overall threat types and high-severity threat types under FWS control were compromised water management capability; habitat shifting/alteration; altered flow regimes; loss/ alteration of wetland habitat; and legal challenges or fines for non-compliance with water policy, law, or regulation. A total of 68 percent of overall need occurrences and 67 percent of all high-priority need occurrences were under the control of the FWS. The most common overall need types and high-priority needs types under control were repair or replace water management infrastructure, water supply/quantity monitoring, water quality baseline monitoring, and protect habitat from invasive species. A Water Resource Inventory and Assessment was also a common overall need under FWS control, as was the highpriority need of water level monitoring. 


\section{Introduction}

The mission of the U.S Fish and Wildlife Service (FWS) National Wildlife Refuge System is to manage a network of National Wildlife Refuges (NWRs) for the conservation, management, and restoration of wildlife, fish, and plants and their habitats within the United States for the benefit of present and future generations of Americans (FWS, 2019a). Water is a critical natural resource of NWRs and is integral to ecosystems and landscapes that provide critical habitat for numerous native threatened and endangered bird, fish, plant, and other aquatic and terrestrial species. Threats to water resources at NWRs can negatively affect the mission of the National Wildlife Refuge System as a whole and at individual refuges.

Water resources are particularly critical for the ecosystems and landscapes in the FWS Legacy Mountain-Prairie Region (LMPR) (formerly Region 6) in the central and western United States, which mostly has a semi-arid climate and has limited water resources in areas. The LMPR contains 117 refuges in Colorado, Kansas, Montana, Nebraska, North Dakota, South Dakota, Utah, and Wyoming (fig. 1, table 1.1). These refuges provide habitat for a wide variety of wildlife. For example, Haliaeetus leucocephalus (bald eagle) roosts along riverine habitat; hundreds of thousands of migratory birds and waterfowl rest at marshes, wetlands, and prairie pothole lakes; and Cervus elaphus (elk) winter in high mountain valleys (FWS, 2019b). In its establishment documents, each refuge has a primary statutory purpose of conserving wildlife that are dependent on refuge land and water (FWS, 2019a).

In the LMRP, refuges report numerous threats to water resources such as a compromised ability to manage water, habitat degradation, insufficient water supply, poor water quality, sedimentation, and water infrastructure deterioration. These types of threats can negatively affect the water resources needed for wildlife, aquatic biota, and plants (Higgins, 2012). Management needs to address the threats to water resources are also numerous. Necessary management actions can include aquatic habitat mapping, monitoring of water quality, exercising water rights, restoring habitat, and repairing or replacing water management infrastructure. Although water is a known critical resource, the quantification or evaluation of waterresource threats and needs for refuges in the LMPR has not been completed on a regional basis; nor have the threats, needs, and refuges been prioritized for effective conservation efforts. Knowledge of specific threats and needs data can facilitate prioritization of conservation efforts among refuges nationally or regionally as well as within individual refuges. The evaluation of threats and needs throughout the region can facilitate an understanding of water resources on an ecosystem level for protection of fish and wildlife.

The U.S. Geological Survey, in cooperation with the FWS, began a study in 2019 to compile, quality assure, and characterize water-resource threats and needs data for the 117 refuges in the LMPR. Specific objectives of the study were (1) to quality assure existing threats and needs data for 86 LMPR refuges and compile additional threats and needs data;
(2) to compile and quality assure threats and needs data for an additional 31 LMPR refuges with no existing threats and needs data; (3) to characterize the threats and needs data using statistical, graphical, and mapping techniques; (4) to rank and prioritize overall threats and needs for the LMPR and by refuges throughout the region; and (5) to upload new and revised quality assured threats and needs data for the LMPR refuges to the FWS Environmental Conservation Online System (ECOS) Water Resource Inventory and Assessment (WRIA) application. This study was initiated to characterize the waterresource threats and needs, provide a status report of the water resources for the region, and potentially identify areas where further investigation may be needed to study environmental factors that contribute to the presence of threats. Knowledge of water-resource threats and needs also aids refuge staff and regional and national FWS management in identifying and prioritizing steps to address current threats, identify future threats, and to direct human and financial resources to critical needs (Higgins, 2012).

\section{Purpose and Scope}

The purpose of this report is to characterize waterresource threats and needs for the $117 \mathrm{FWS}$ refuges in the LMPR. The report includes (1) the compilation and quality assurance of current (April 2020) water-resource threats and needs data for the refuges in the LMPR and (2) the statistical, graphical, and spatial characterization of the threats and needs dataset. The characterization includes the ranking and prioritizing of water-resource threat types, threat causes, and needs by the number of occurrences in the LMPR as a whole and by refuges, states, and select U.S. Environmental Protection Agency (EPA) Level III Ecoregions.

\section{Description of Study Area}

The FWS LMPR is a geographically diverse region of the Great Plains and western United States (fig. 1) that is defined by three distinct landscapes (FWS, 2019b). The northeastern portion of the region contains the Prairie Pothole Region in North and South Dakota (fig. $1 B$ ), an area with millions of "prairie potholes:" shallow wetlands in formerly glaciated areas that are highly productive for waterfowl breeding (FWS, 2019b). The LMPR's eastern portion is primarily mixedand short-grass prairies of the central and northern Great Plains. The western portion of the LMPR includes the Rocky Mountains and parts of the Colorado Plateau and the Great Basin. The LMPR refuges are in 15 of 16 EPA Level III ecoregions labelled on figure 2 (table 1.1) (EPA, 2018). The Level III ecoregions are based on patterns of biotic and abiotic factors, such as climate, geology, soils, vegetation, physiography, and land use (Omernik, 1987). About 68 percent (79 of 117) of refuges are in the Northern Glaciated Plains, Northwestern Glaciated Plains, and Northwestern Great Plains Level III ecoregions (table 1.1). 

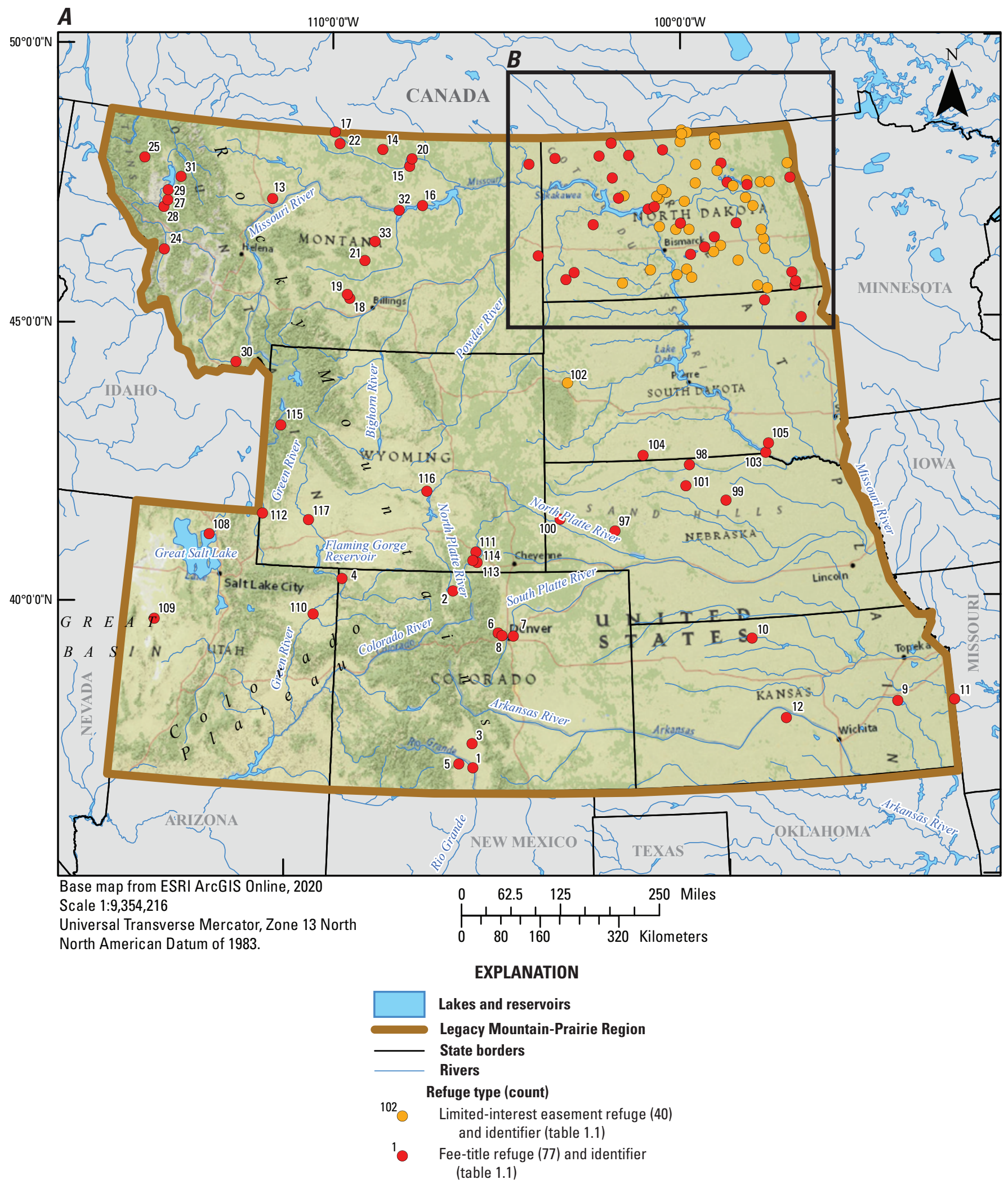

Figure 1. A, locations of U.S. Fish and Wildlife Service National Wildlife Refuges in the Legacy Mountain-Prairie Region and $B$, refuge locations in North Dakota. Dots on the map approximate the physical location of the refuge, not the size of the refuge. 


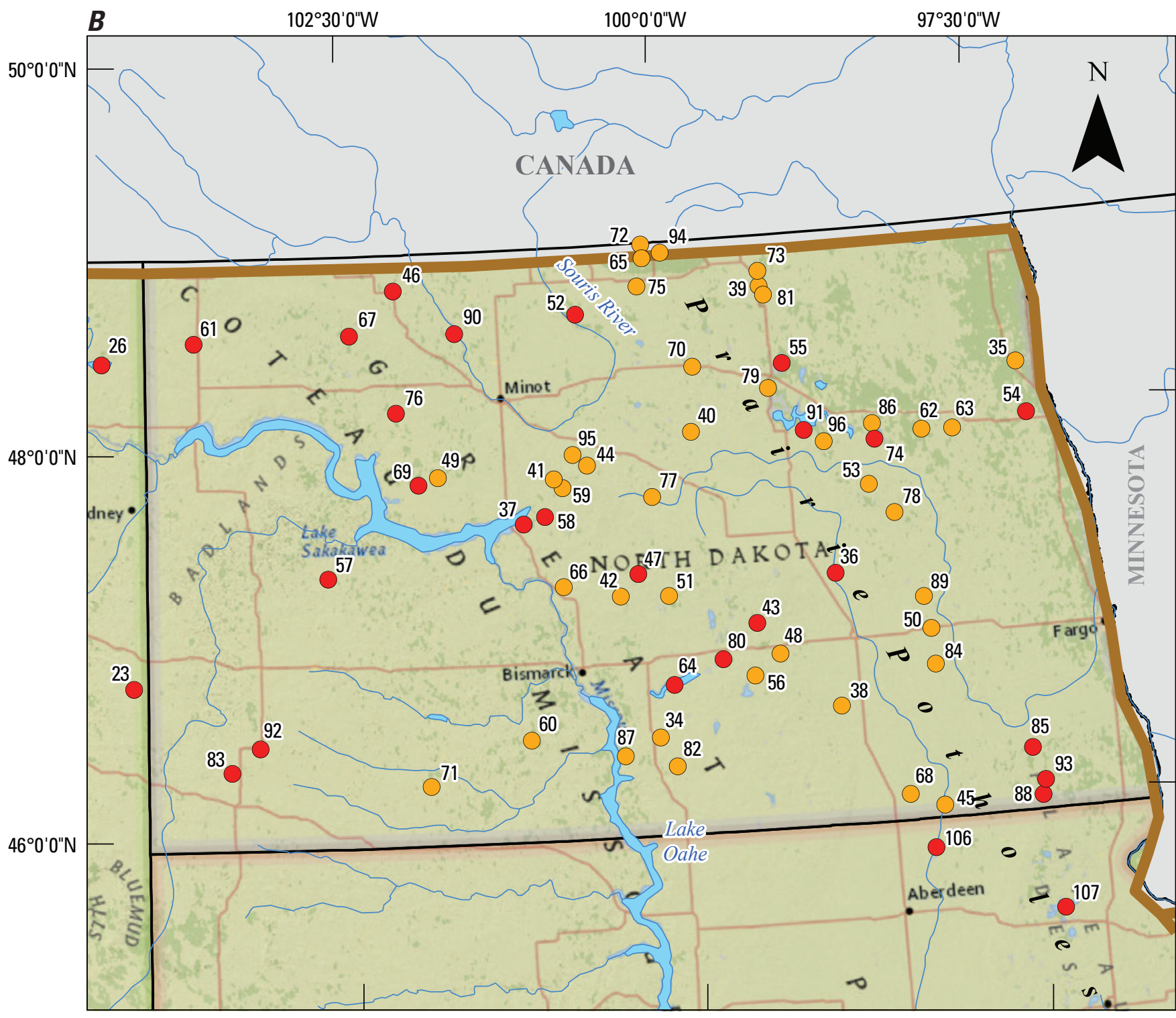

Base map from ESRI ArcGIS Online, 2020 Scale 1:4,243,976

Universal Transverse Mercator, Zone 13 North North American Datum of 1983.

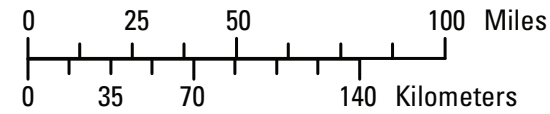

\section{EXPLANATION}

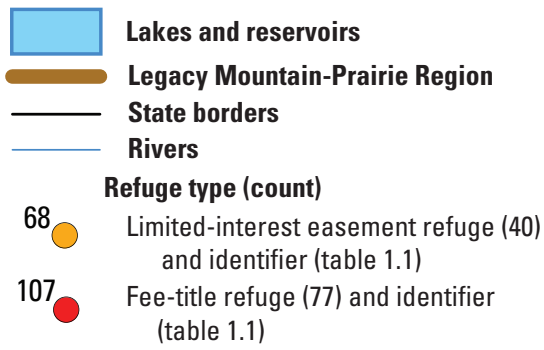

Figure 1. A, locations of U.S. Fish and Wildlife Service National Wildlife Refuges in the Legacy Mountain-Prairie Region and $B$, refuge locations in North Dakota. Dots on the map approximate the physical location of the refuge, not the size of the refuge.-Continued 


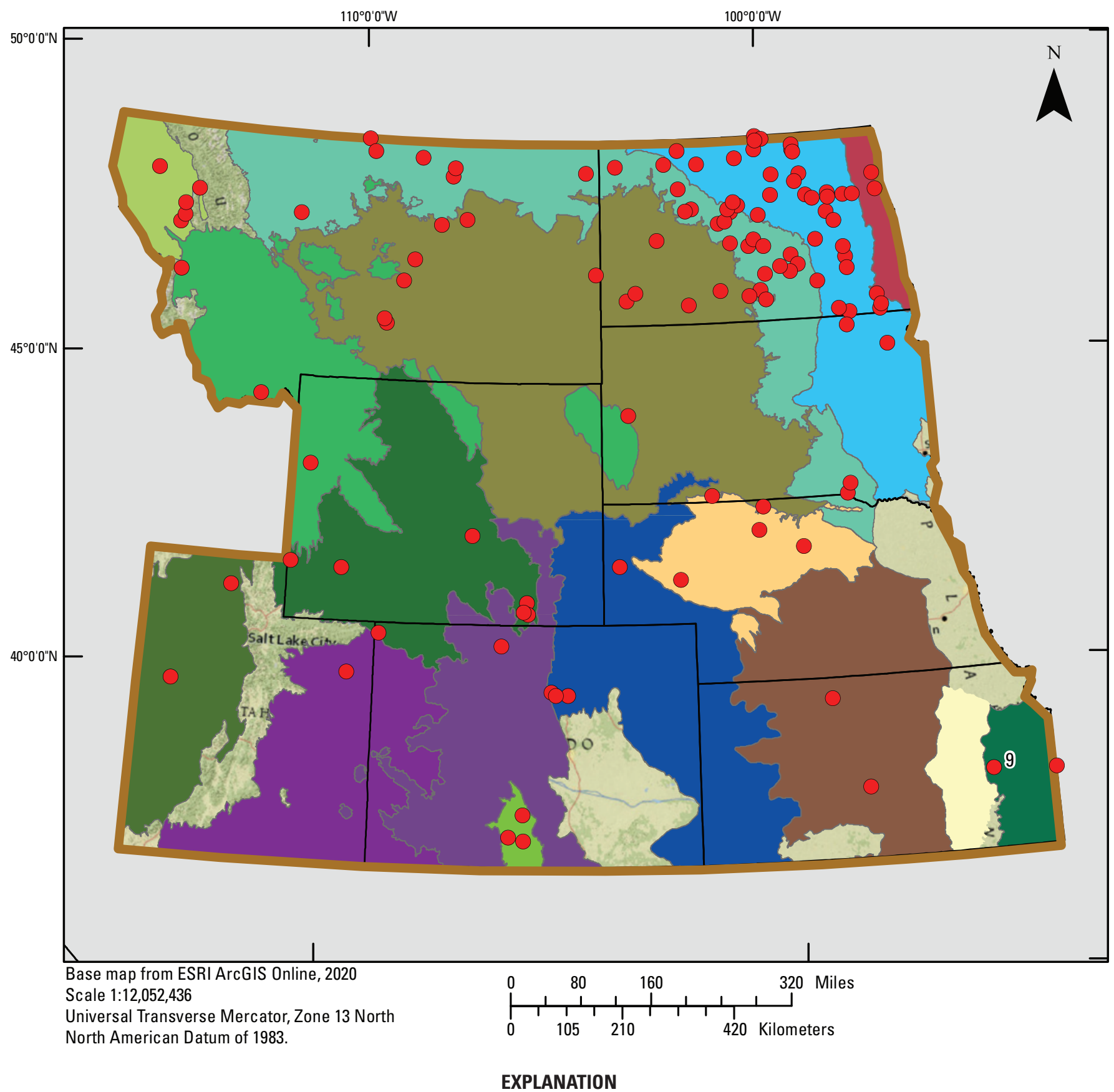

\section{EPA Level III Ecoregions}

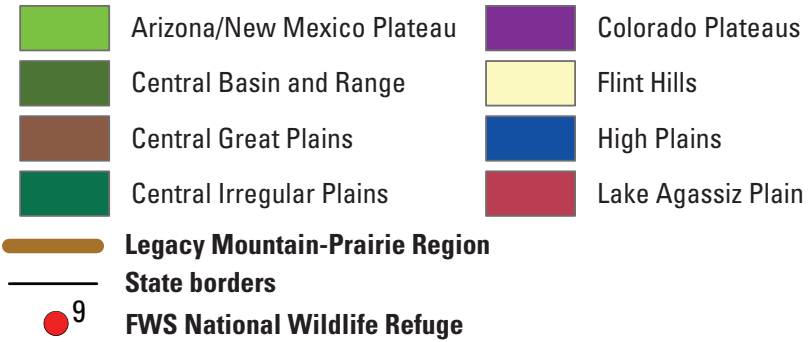

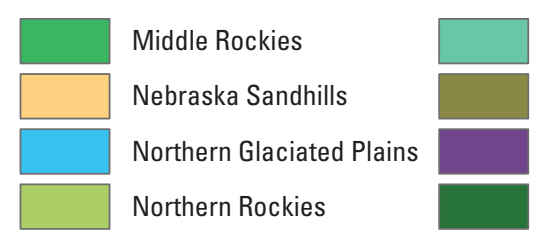

Northwestern Glaciated Plains Northwestern Great Plains Southern Rockies

Wyoming Basin

Figure 2. U.S. Environmental Protection Agency (EPA) Level III Ecoregion boundaries and locations of U.S. Fish and Wildlife Service (FWS) National Wildlife Refuges in the Legacy Mountain-Prairie Region. (On the map, the Flint Hills National Wildlife Refuge [\#9] is in the Central Irregular Plains Level III Ecoregion. The refuge Comprehensive Conservation Plan [FWS, 2000] reports that the refuge is in the Flint Hills Level III Ecoregion.) 
The management of refuge land and water resources for wildlife conservation is dependent on the statutory purpose for which each refuge was established. Ouray NWR in northeast Utah, for example, was established in 1960 to provide prime breeding, resting, and feeding area for migratory waterfowl. Its management goals include the restoration and enhancement of riparian and wetland habitats along the Green River and the creation of opportunities for compatible wildlife-dependent recreation (Striffler and Shafer, 2016). About 66 percent (77 of 117) of refuges in the LMPR are fee-title refuges (fig. 1), meaning the FWS owns most or all land within a refuge boundary (FWS, 2017b). Inholdings of private property on a fee-title refuge can be fully controlled by the property owner or may be held as a conservation easement to protect vital wildlife habitat. A conservation easement pays a landowner to permanently protect wetlands or other land on the property without relinquishing ownership. Eleven fee-title refuges, known as satellite refuges, are unstaffed and administered by other refuges (table 1.1). The remaining refuges are limitedinterest easement refuges, all but one of which are in North Dakota (fig. 1, table 1.1). These refuges were established in the 1930s and 1940s for the purposes of water conservation, drought relief, and migratory bird and wildlife conservation, and to provide work opportunities building dams and other refuge infrastructure (FWS, 2006). Almost all limited-interest easement land is privately owned, so the FWS has limited management capabilities on these refuges aside from management of water use and hunting and trapping (FWS, 2006).

\section{Methods}

Water-resource threats and needs for the LMPR refuges were compiled from several sources and quality assured. Statistical, graphical, and mapping techniques were used to characterize the threats and needs presented in this report.

\section{Data Compilation and Quality Assurance}

The FWS ECOS website (https://www.fws.gov/southeast/ conservation-tools/environmental-conservation-onlinesystem/) is a centralized access point to FWS data systems (FWS, 2017a). On the ECOS website, the WRIA application is standardized so that users can identify multiple threats and needs parameters, with each parameter having multiple domain values (tables 1 and 2). Each threat and need parameter can be filtered by domain values for data retrieval. The domain values are restricted to selections in dropdown menus in the WRIA application, which enables consistency in characterization of threats and needs across FWS management units. For example, domain values of threat type related to aquatic habitat, water quality, or water quantity include habitat shifting/alteration and impaired stream connectivity (aquatic habitat), nutrient pollution and turbidity (water quality), and altered flow regimes and excess surface water (water quantity). Domain values of threat cause include agricultural runoff, dams, droughts, invasive species, lack of water management infrastructure, and water diversions. Refuge threats and needs data are available to the public through the FWS Snapshot application (https://secure.login.gov/?request_ id=93ee0bf4-5993-4736-aa2b-aa75bedacff1). To access

Table 1. Information for water-resource threats available in the U.S. Fish and Wildlife (FWS) Environmental Conservation Online System Water Resource Inventory and Assessment (WRIA) application.

\begin{tabular}{ll}
\hline \multicolumn{1}{c}{ Threat parameter } & \multicolumn{1}{c}{ Domain value $^{2}$} \\
\hline Region & 8 domain values \\
Refuge & About 730 domain values \\
Threat Type & 32 domain values \\
Threat Cause & 89 domain values related to climate, landscape alteration, water management \\
& capability, water quality, water rights/legal causes, water supply/quantity \\
Threat Status & Current, future, mitigated \\
Threat Severity & High, moderate, low, unknown \\
Threat Time Frame & Existing, medium-term, long-term \\
Can FWS Handle This Alone & Yes, no \\
Origin of Threat Information & 13 domain values \\
Quality/Reliability of Information & High, medium, low/unknown \\
\hline
\end{tabular}

${ }^{1}$ Each threat parameter can be filtered for specific domain values.

${ }^{2}$ Domain values are restricted to specific selections in dropdown menus in the WRIA application. Count of domain values are for threats nationally.

3Includes National Wildlife Refuges, Conservation Areas, National Fish Hatcheries, Wetland Management Districts, and Wildlife Management Areas.

4The 32 domain values for threat types are grouped into the categories of aquatic habitat (10 threat types), water quality (15 threat types), or water quantity (7 threat types) for purposes of this report. These categories are not included in the WRIA application. 
Table 2. Information for water-resource needs available in the U.S. Fish and Wildlife (FWS) Environmental Conservation Online System Water Resource Inventory and Assessment (WRIA) application.

\begin{tabular}{ll}
\hline \multicolumn{1}{c}{ Need parameter ${ }^{1}$} & \multicolumn{1}{c}{ Domain value $^{2}$} \\
\hline Region & 8 domain values nationally \\
Refuge & About 730 domain values ${ }^{3}$ \\
Need Level 1 Type & 8 domain values \\
Need Level 2 Type & 67 domain values \\
Need Status & Current, future, initiated, mitigated \\
Need Priority & High, moderate, low/unknown \\
Need Effort & Major, minor \\
Need Time Line & Short-term, medium, long-term \\
Can FWS Handle This Alone & Yes, no \\
Origin of Need Information & 13 domain values \\
Quality/Reliability of Information & High, medium, low/unknown \\
\hline
\end{tabular}

1Each need parameter can be filtered for specific domain values.

2Domain values are restricted to specific selections in dropdown menus in the WRIA application. Count of domain values are for needs nationally.

3Includes National Wildlife Refuges, Conservation Areas, National Fish Hatcheries, Wetland Management Districts, and Wildlife Management Areas.

the Snapshot application, an ECOS account is first needed. Creation of an account for ECOS is available to the public through the website.

Domain values of needs include "Need Level 1 Type" and "Need Level 2 Type." The "Need Level 1 Type" (henceforth, "need category") are categories of needs and include the domain values of Coordination/Support, Mapping and Geospatial Data/Analysis, Modeling/Research/Assessment, Monitoring/Measurement, Water Quality Mitigation/Habitat Improvement, Water-Related Infrastructure, Water Rights/ Water Entitlements, and Water Supply/Management. The "Need Level 2 Type" (henceforth "need type") are specific refuge needs. For example, domain values of need type include aquatic habitat mapping, groundwater modeling, water level monitoring, protect habitat from invasive species, remove infrastructure, exercise water rights, and seek legislative relief/ assistance (such as for insufficient staffing levels at refuges). Domain values of origin of threat and need information include management plan, on-site observation, and personal communication with refuge staff, for example (FWS, 2017a).

Identifying causes of water-resource threats is considered necessary to determine mitigation strategies, as each cause could necessitate a different mitigation technique or method. Threats are rated for severity (high, moderate, low, unknown) and needs for priority (high, moderate, low/unknown) (tables 1 and 2). High-severity threats are those for which the FWS has determined that the threat could negatively affect the conservation mission of the refuge. High-priority needs are those necessary for a refuge to fulfill its conservation mission and water-resource management objectives. Knowledge of FWS ability to handle a threat or need with or without outside assistance is included in the WRIA application because refuges are often at the receiving end of potential effects from upstream activities such as water diversions, flooding, and agricultural runoff that the refuge may or may not have control over for mitigation strategies.

When the data were retrieved from the WRIA application in June 2019, threats and needs were available for 86 of 117 refuges (table 1.1). Most refuges had both threats and needs, but a few had only threats or only needs. The data in the WRIA application for the 86 refuges were originally compiled by refuge staff and staff of the LMPR Division of Water Resources (DWR). An example of threats and needs data obtained from the application is shown in table 3 for the Bear River Migratory Bird Refuge (MBR) in northern Utah. The retrieved data were quality assured by first reviewing the data for completeness and correctness and by subsequently identifying data that did not agree with the standardization system in the WRIA application. A thorough search of FWS websites and publications in the FWS catalog database ServCat (FWS, 2020) and other websites and publications was conducted to verify the threats and needs data and to identify additional threats and needs. Refuge and DWR staff were contacted to verify that the existing and newly compiled threats and needs dataset was appropriate and accurate.

For the 31 refuges with no threats and needs data in the WRIA application, similar steps as those taken for refuges with data in the application were used to identify, compile, and quality assure threats and needs. Publications and websites were searched, and the newly compiled threats and needs dataset was sent to appropriate refuge staff for review and quality assurance. Additional threats and needs data identified by refuge and DWR staff were added to the initial compilation for the 31 refuges, following the standardization system in the WRIA application (tables 1 and 2). 
Table 3. Example threats and needs data in the U.S. Fish and Wildlife Service (FWS) Environmental Conservation Online System Water Resource Inventory and Assessment (WRIA) application for Bear River Migratory Bird Refuge in Utah.

[Na, not applicable]

\begin{tabular}{|c|c|c|c|}
\hline \multicolumn{2}{|c|}{ Threat ${ }^{1}$} & \multicolumn{2}{|r|}{ Need1 } \\
\hline Title $^{2}$ & Urban runoff & Title $^{2}$ & Seasonal water quality changes \\
\hline Threat Type & Nutrient pollution & Need Level 1 Type & Monitoring/Measurement \\
\hline Threats Status & Current & Need Status & Current \\
\hline Threat Severity & Moderate & Need Priority & High \\
\hline Can FWS Handle This Alone & No & Need Time Line & Short-term \\
\hline Description $^{2}$ & $\begin{array}{l}\text { Development along the Bear } \\
\text { River floodplain and adja- } \\
\text { cent valley floors has led } \\
\text { to several locations where } \\
\text { urban runoff and its associ- } \\
\text { ated pollutants enters the } \\
\text { watershed }\end{array}$ & Can FWS Handle This Alone & Yes \\
\hline $\begin{array}{l}\text { Quality/Reliability of } \\
\text { Information }\end{array}$ & High & Origin of Need Information & $\begin{array}{l}\text { Personal communication with refuge } \\
\text { staff }\end{array}$ \\
\hline $\mathrm{Na}$ & $\mathrm{Na}$ & $\begin{array}{l}\text { Quality/Reliability of } \\
\text { Information }\end{array}$ & High \\
\hline
\end{tabular}

${ }^{1}$ Except for title and description of a threat or need, all other information for threats and need parameters is restricted to specific domain values on dropdown menus in the WRIA application.

2Title and description are included in a data retrieval from the WRIA application. They are not specific threat or need parameters on dropdown menus in the WRIA application.

The threats and needs data for the 86 refuges compiled from the WRIA application and subsequently quality assured were combined with the newly compiled and quality assured data for the 31 refuges originally without threats and needs information. The resulting threats and needs dataset is considered to be correct as of April 2020 and is presented in this report. The new and revised data were subsequently uploaded to the ECOS database.

\section{Statistical, Graphical, and Mapping Techniques}

In the WRIA application, differences exist in how threats and needs are interpreted and reported among refuges. For example, the threat type of altered flow regime is listed multiple times with multiple causes for some refuges and is listed once with a single cause for other refuges. To minimize potential bias in reporting for this report, multiple occurrences of a particular threat type, threat cause, and need type within a single refuge were counted as one unique occurrence. This provides for a count of unique threat types, causes, and need types for a refuge rather than a total count of threat types, causes, and need types.

The threats and needs data were characterized using statistical, graphical, and mapping techniques. Summary statistics and bar graphs were generated using the R software environment version 3.6.1 (R Core Team, 2020). Counts and bar graphs were made for the most common threat and highseverity threat types and their causes. This was also done for the most common aquatic habitat, water quality, and water quantity threat types and causes; the most common needs and high-priority needs; and for refuges, states, and select ecoregions with the most threat types, causes, and need types. A ranking scheme was developed to identify refuges that have the highest-ranking priority for conservation efforts based on threats and needs data in the WRIA application. Each refuge was ranked by count of occurrences of high-severity threats and high-priority needs. A higher overall ranking value can correspond to a greater need for conservation than a lower overall ranking value. 
Maps displaying various threats and needs data for the LMPR were developed using ArcGIS software (Esri, 2020). Counts of threats and high-severity threat types, needs, and high-priority needs were developed spatially for each refuge. The severity rating of the most common threat types and threat causes for each refuge and the total count of each severity rating for the LMPR also were developed spatially. This mapping was also done for the most common need types for each refuge.

\section{Characterization of Water-Resource Threats and Needs}

The compiled threats and needs dataset resulted in the identification of 540 threat occurrences (unique threat type/ refuge combination) for 109 refuges and 29 threat types (tables 4 and 1.1). No threats were identified for eight refuges: Ninepipe, Pablo, and War Horse NWRs in Montana; Half-Way Lake, Lost Lake, School Section Lake, and Wild Rice NWRs in North Dakota; and Bear Butte NWR in South Dakota (table 1.1). For needs, 637 unique need occurrences (unique need/refuge combination) for 114 refuges and 62 need types were identified (tables 4 and 1.1). No needs were identified for three refuges: Half-Way Lake and School Section Lake NWRs in North Dakota and Bear Butte NWR in South Dakota (table 1.1).

\section{Water-Resource Threats}

The 540 unique water-resource threat occurrences were grouped into 1 of 3 categories - aquatic habitat, water quality, or water quantity - for purposes of this report; the categories themselves are not included in the WRIA application of the ECOS database. The 10 most common water-resource threat types on refuges and their related category grouping are shown in figure $3 \mathrm{~A}$. These top 10 threat types represented about 70 percent ( 380 of 540) of all threat occurrences within the LMPR. Individually, each top 10 threat type was reported at 24-64 refuges (fig. 3A). The spatial distribution of the top three threat types (compromised water management capability, habitat shifting/alteration, and altered flow regimes) are shown in appendix 1, figures 1.1-1.3. Only about 33 percent (177 of 540) of threat occurrences could be handled by the FWS alone (table 4), meaning that the FWS would not need outside assistance (such as that from upstream landowners or other government agencies) to mitigate 33 percent of refuge threat occurrences. This determination is based on the specific parameter "Can FWS Handle This Alone" in the WRIA application (table 1).

About 43 percent (230 of 540) of all threat occurrences had a high-severity threat rating (table 4). A total of 59 refuges had 1 or more high-severity threats types (table 4), which means that 54 percent of refuges with threats had at least 1 threat severe enough to potentially affect the conservation mission of the refuge. The top 10 high-severity threat types represented about 31 percent (165 of 540) of all threat occurrences, and each threat type was reported at 9-29 refuges (fig. $3 B$ ). Eight of the top 10 threat types also were 8 of the top 10 high-severity threat types (figs. $3 A$ and $3 B$ ). Only about 37 percent ( 84 of 230) of high-severity threat occurrences could be handled by the FWS alone (table 4).

Table 4. Summary of threat and needs types for U.S. Fish and Wildlife (FWS) National Wildlife Refuges in the Legacy Mountain-Prairie Region for all unique occurrences and occurrences handled by the FWS alone, number of refuges, and number of unique causes.

[No., Number; na, not applicable]

\begin{tabular}{|c|c|c|c|c|}
\hline \multirow[b]{2}{*}{ Threat and need type (No.) } & \multicolumn{2}{|c|}{ No. of unique occurrences } & \multirow[b]{2}{*}{$\begin{array}{l}\text { No. of } \\
\text { refuges }\end{array}$} & \multirow[b]{2}{*}{$\begin{array}{c}\text { No. of } \\
\text { unique causes }\end{array}$} \\
\hline & All & $\begin{array}{c}\text { Handled by FWS } \\
\text { alone }\end{array}$ & & \\
\hline High-severity threat type (25) & 230 & 84 & 59 & 59 \\
\hline Aquatic-habitat threat type (9) & 177 & 76 & 71 & 46 \\
\hline High-severity threat type (10) & 56 & 10 & 22 & 31 \\
\hline Water-quantity threat type (7) & 189 & 75 & 93 & 53 \\
\hline High-severity threat type (7) & 90 & 34 & 36 & 43 \\
\hline All need types (62) & 637 & 434 & 114 & na \\
\hline
\end{tabular}



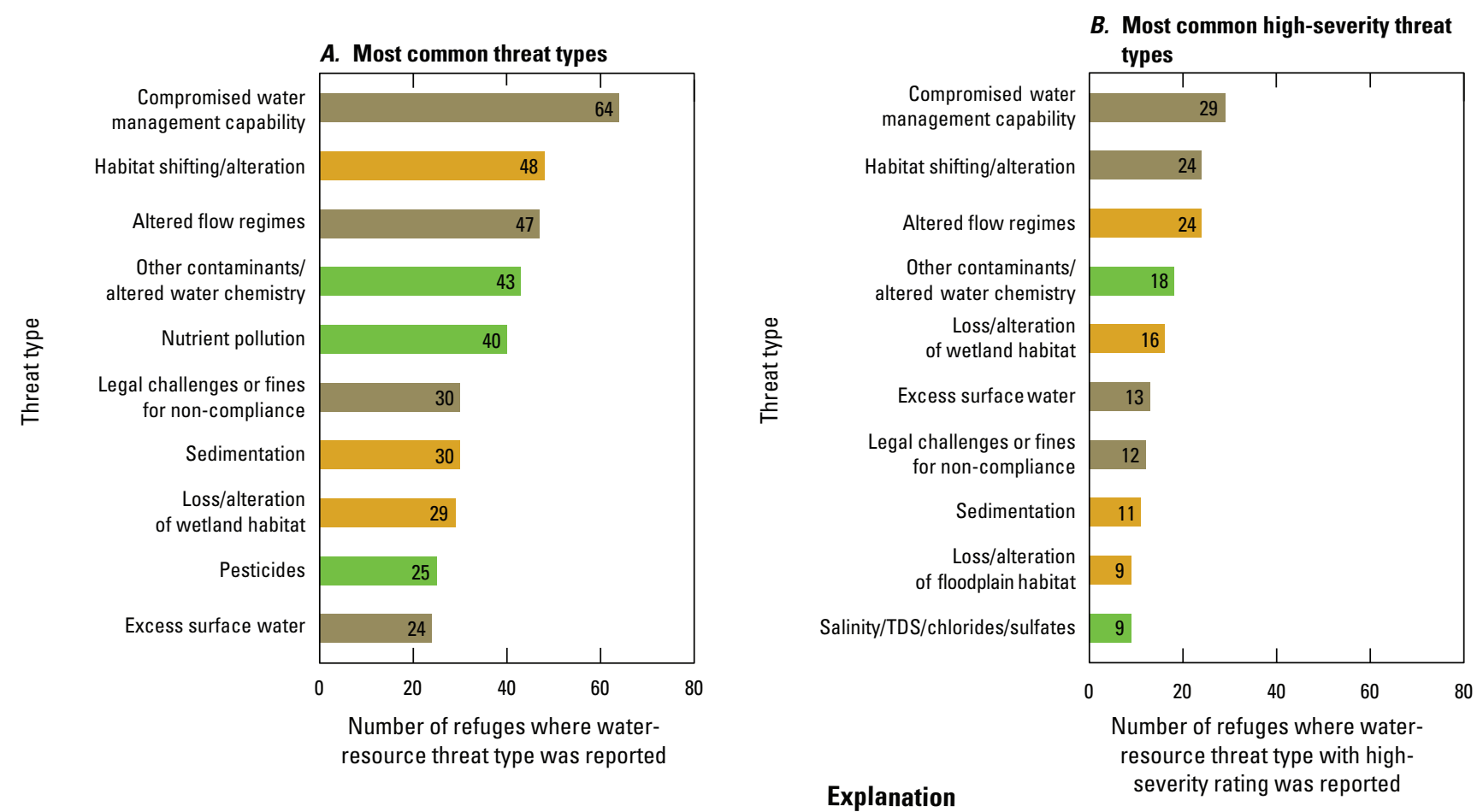

\begin{tabular}{|c|c|c|}
\hline \multicolumn{3}{|c|}{ Explanation } \\
\hline Aquatic habitat & & Water-quantity \\
\hline Water-quality & 9 & $\begin{array}{l}\text { Number in bar represents } \\
\text { number of refuges }\end{array}$ \\
\hline
\end{tabular}
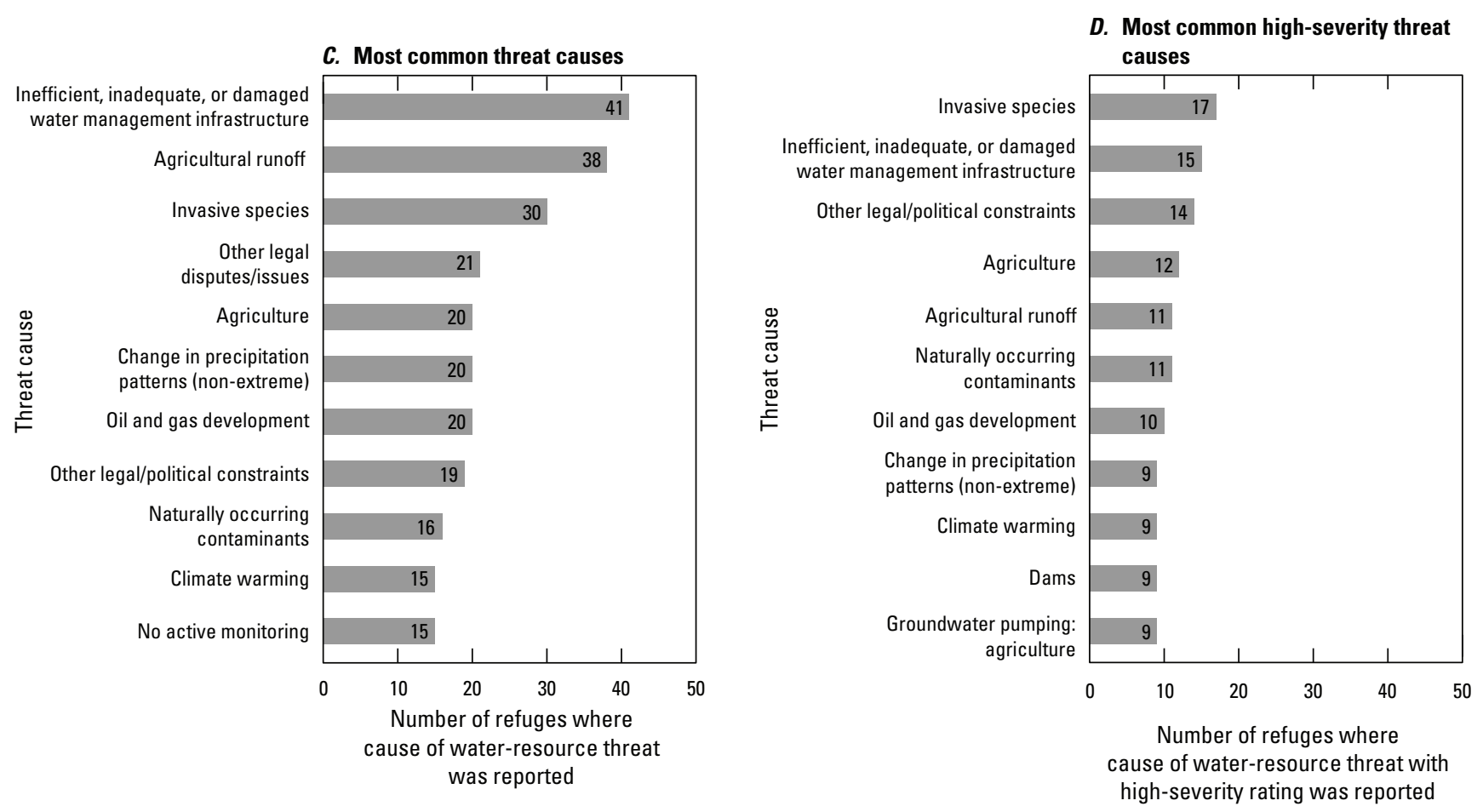

Figure 3. $A$, the 10 most common water-resource threat types; $B$, the 10 most common high-severity water-resource threat types; $C$, the 11 most common causes of water-resource threats; and $D$, the 11 most common causes of high-severity water-resource threats on U.S. Fish and Wildlife Service National Wildlife Refuges in the Legacy Mountain-Prairie Region and the number of refuges where each threat type and cause were reported (TDS, total dissolved solids. Number in bar represents the number of refuges). 
A total of 72 unique causes of water-resource threats were reported for refuges in the LMPR (table 4). Each of the 11 most common causes was reported at 15-41 refuges (fig. 3C). About 82 percent (59 of 72) of all threat causes were associated with high-severity threat types (table 4). The top 11 causes for high-severity threats were reported at 9-17 refuges each (fig. 3D). Nine of the top 11 causes of threats also were 9 of the top 11 causes of high-severity threats (figs. $3 C$ and $3 D$ ). The spatial distribution of the top three threat causes (inefficient, inadequate, or damaged water management infrastructure; agricultural runoff; and invasive species) are shown in appendix 1, figures 1.4-1.6.

Compromised water management capability was the most common water-resource threat type reported (64 refuges) and the most common high-severity threat type (29 refuges) (figs. $3 A, 3 B$, and 1.1 ; tables 5 and 6 ). Water management capability was compromised when refuge staff were unable to adequately manage water (such as manipulating headgates for water delivery) or when management was outside of their control. This was most commonly because of inefficient, inadequate, or damaged water management infrastructure; no active monitoring; and other legal/political constraints (table 5). These causes were also the most common causes of the high-severity compromised water management capability threats (table 6).

Habitat shifting/alteration was the second most common overall threat type (48 refuges) and tied for second for highseverity threat type (24 refuges) (figs. $3 A, 3 B$, and 1.2; tables 5 and 6). The most common causes of the habitat shifting/alteration threat type overall were invasive species, climate warming, agricultural runoff, and change in non-extreme precipitation patterns (table 5). For the habitat shifting/alteration threats with a high-severity rating, the most common causes were invasive species; climate warming; inefficient, inadequate, or damaged water management infrastructure; and oil and gas development (table 6).

Table 5. The three most common water-resource threat types on U.S. Fish and Wildlife National Wildlife Refuges in the Legacy Mountain-Prairie Region and the most common causes of each threat type.

[Number in parentheses is a count of refuges reporting the common threat type or the common threat cause. The most common threat types and count of refuges for each threat are shown in figure $3 \mathrm{~A}$. The threat types, their causes, and number of refuges with the threat or cause are from the Environmental Conservation Online System (U.S. Fish and Wildlife Service, 2017a)]

\begin{tabular}{|c|c|c|c|}
\hline \multirow{2}{*}{$\begin{array}{l}\text { Most common threat } \\
\text { cause }\end{array}$} & \multicolumn{3}{|c|}{ Most common threat type } \\
\hline & $\begin{array}{c}\text { 1st. compromised water } \\
\text { management capability (64) }\end{array}$ & 2nd. habitat shifting/alteration (48) & 3rd. altered flow regimes (47) \\
\hline 2nd most common cause & No active monitoring (12) & Climate warming (6) & $\begin{array}{l}\text { Groundwater pumping: agricul- } \\
\text { ture }(8)\end{array}$ \\
\hline
\end{tabular}

Table 6. The three most common high-severity water-resource threat types on U.S. Fish and Wildlife National Wildlife Refuges in the Legacy Mountain-Prairie Region and the most common causes of each high-severity threat type.

[Number in parentheses is a count of refuges reporting the common high-severity threat type or the common threat cause. The most common high-severity threat types and count of refuges for each threat are shown in figure $3 B$. The high-severity threat types, their causes, and number of refuges with the high-severity threat or cause are from the Environmental Conservation Online System (U.S. Fish and Wildlife Service, 2017a)]

\begin{tabular}{|c|c|c|c|}
\hline \multirow{2}{*}{$\begin{array}{l}\text { Most common threat } \\
\text { cause }\end{array}$} & \multicolumn{3}{|c|}{ Most common high-severity threat type } \\
\hline & $\begin{array}{c}\text { 1st. compromised water } \\
\text { management capability (29) }\end{array}$ & $\begin{array}{c}\text { 2nd (tied). habitat } \\
\text { shifting/alteration (24) }\end{array}$ & $\begin{array}{l}\text { 2nd (tied). altered flow } \\
\text { regimes (24) }\end{array}$ \\
\hline 2nd most common cause & $\begin{array}{l}\text { Inefficient, inadequate, or damaged } \\
\text { water infrastructure ( } 7)\end{array}$ & Climate warming (4) & Climate warming (5) \\
\hline
\end{tabular}


Altered flow regimes was the third most common overall threat type (47 refuges) and was tied for second for highseverity threat type ( 24 refuges) (figs. $3 A, 3 B$, and 1.3 ; tables 5 and 6). Flow was altered when the hydrology at a refuge was changed from its natural or normal state, and the function of the refuge was negatively affected as a result. The most common causes of altered flows were change in non-extreme precipitation patterns, pumping of groundwater for agriculture, and dams (table 5). For the high-severity altered flow regimes threats, the most common causes were groundwater pumping for agriculture; climate warming; dams; and inefficient, inadequate, or damaged water management infrastructure (table 6).

\section{Aquatic-Habitat Threats}

One or more of 9 aquatic-habitat threat types were reported at about 65 percent (71 of 109) of refuges and accounted for about 33 percent of all threat occurrences (177 of 540) (table 4). Each aquatic-habitat threat type and the number of refuges reporting each threat type are shown in figure $4 \mathrm{~A}$. Nearly 90 percent ( 8 of 9 ) of aquatic-habitat threat types had a high-severity rating (fig. $4 B$ ). These were reported at about 35 percent (38 of 109) of refuges and made up about 16 percent ( 84 of 540) of all threat occurrences (table 4 ). The top aquatichabitat threat types, including those for high-severity threats, were habitat shifting/alteration, loss/alteration of wetland habitat, and sedimentation (figs. $4 A$ and $4 B$ ). The top three causes of aquatic-habitat threats and high-severity threats were invasive species; agriculture; and inefficient, inadequate, or damaged water management infrastructure (figs. $4 C$ and $4 D$ ).

\section{Water Quality Threats}

About 62 percent (67 of 109) of refuges had threats related to water quality, which accounted for about 32 percent (174 of 540) of water-resource threat occurrences (table 4). The top 10 of the 13 water-quality threat types reported for refuges are shown in figure $5 \mathrm{~A}$. Each of these top 10 threat types also was a top 10 high-severity threat type (fig. $5 B$ ). The high-severity threat types were reported at about 20 percent (22 of 109) of refuges and made up about 10 percent (56 of 540) of all threat occurrences (table 4). Most water-quality threats are caused by current and historical land uses, many of which are upstream from refuges. The four most common water-quality threat types and highseverity threat types were other contaminants/altered water chemistry, nutrient pollution, pesticides, and salinity/total dissolved solids (TDS)/chlorides/sulfates (figs. $5 A$ and $5 B$ ). The threat type of other contaminants/altered water chemistry was used when there was a known water-quality threat, but refuge staff were not able to identify a particular contaminant, or when the contaminant of interest was not a specific domain value in the WRIA application. The top three causes of water-quality threats and high-severity water-quality threats were agricultural runoff, oil and gas development, and naturally occurring contaminants (figs. $5 C$ and $5 D$ ).

\section{Water Quantity Threats}

Threat types related to water quantity were the most common among the three threat categories. About 85 percent $(93$ of 109) of refuges reported 1 or more of the 7 water-quantity threat types, and these threat types accounted for 35 percent (189 of 540) of all water-resource threat occurrences (table 4). The seven water-quantity threat types are shown in figure $6 \mathrm{~A}$. All 7 threat types had a high-severity rating (fig. $6 B$ ), which were reported at about 33 percent (36 of 109) of refuges and made up about 17 percent (90 of 540) of all threat occurrences (table 4). Of the 3 most common threat types and high-severity threat types for water quantity, 2 were similar: compromised water management capability and altered flow regimes (figs. $6 \mathrm{~A}$ and $6 B$ ). Also, 3 of the 4 most common causes of water-quantity threats - inefficient, inadequate, or damaged water management infrastructure; other legal/political constraints; and change in non-extreme precipitation patterns - were the most common causes of severe water-quantity threats (fig. $6 C$ and $6 D$ ).

Many of the reported legal-related causes of waterquantity threats, including other legal disputes/issues and other legal/political constraints, were related to water-rights issues. The ability of a given refuge to divert water, based on the refuge water rights, is important for ensuring adequate water supply for birds and other wildlife at specific times of the year. If insufficient water is available for diverting, a refuge may not be receiving their legally protected share.

\section{Refuges}

Of the 109 refuges with water-resource threats, Long Lake NWR in south-central North Dakota had the most (20) threat types (figs. $7 \mathrm{~A}$ and 8 ; table 1.1). The dominant habitat at this refuge is a 16,000 acre, 2-mile wide and 18-mile long natural, alkaline lake (FWS, 2013). Most (85 percent, 17 of 20) threat types at the refuge were related to water quality (low dissolved oxygen; mercury and metals; nutrients, pesticides, and salts) and aquatic habitat (various losses of habitat such as floodplain, lakes or ponds, stream channels, and wetlands; and sedimentation). Most water-resource threats at Long Lake NWR were caused by agricultural runoff and climate- or precipitation-related causes. None of the threats at the refuge could be handled by FWS alone (FWS, 2017a).

Other refuges with the greatest number of threat types included Marais des Cygnes NWR in eastern Kansas with 18 threat types and Arapaho NWR in north-central Colorado and Lee Metcalf NWR in northwest Montana, each with 16 threat types (figs. $7 A$ and 8 ; table 1.1). At each refuge, there were more aquatic-habitat and water-quality threat types than waterquantity threat types. Most threat occurrences were not under control of the FWS alone (FWS, 2017a).

About 54 percent (59 of 109) of refuges had threats with a high-severity rating (table 4). Arapaho and Quivira NRWs each had 10 high-severity threat types, the maximum number of high-severity threat types (figs. $7 B$ and 9; table 1.1). Among the high-severity threat types at Arapaho NWR, half were 

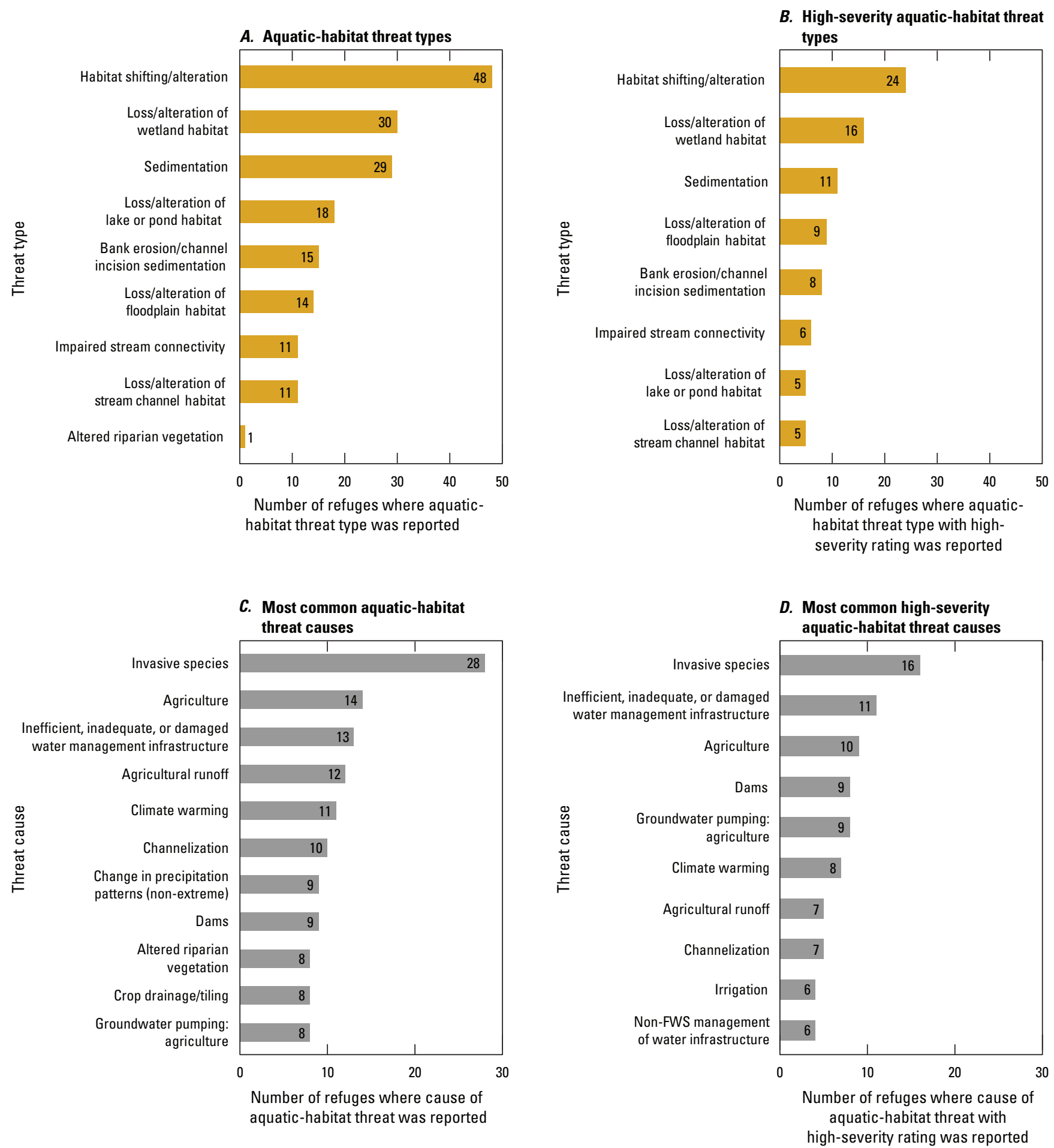

Figure 4. $A$, aquatic-habitat threat types; $B$, high-severity aquatic-habitat threat types; $C$, the most common causes of aquatic-habitat threats; and $D$, the most common causes of high-severity aquatic-habitat threats on U.S. Fish and Wildlife Service (FWS) National Wildlife Refuges in the Legacy Mountain-Prairie Region and the number of refuges where each aquatic-habitat threat type and cause were reported (Number in bar represents the number of refuges). 


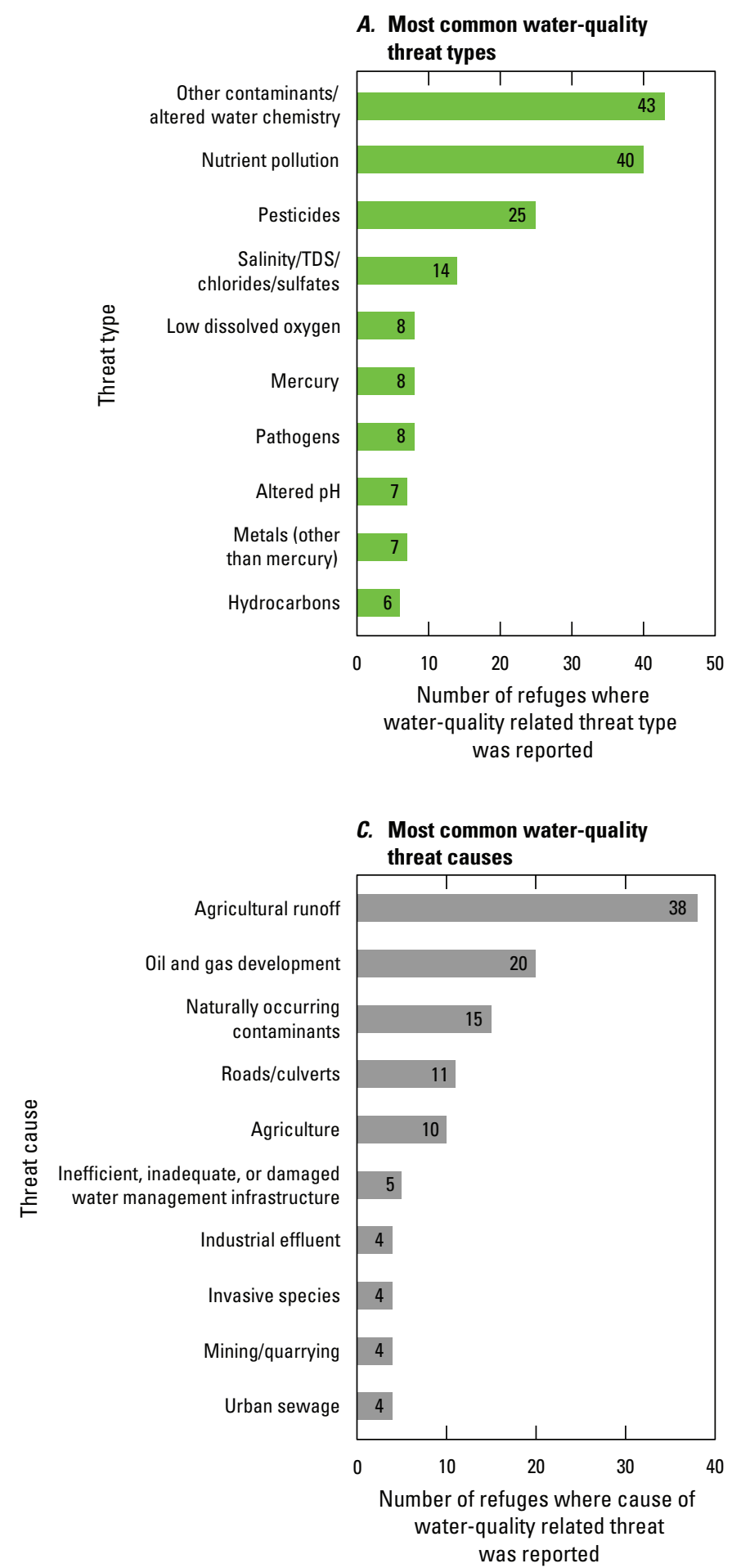

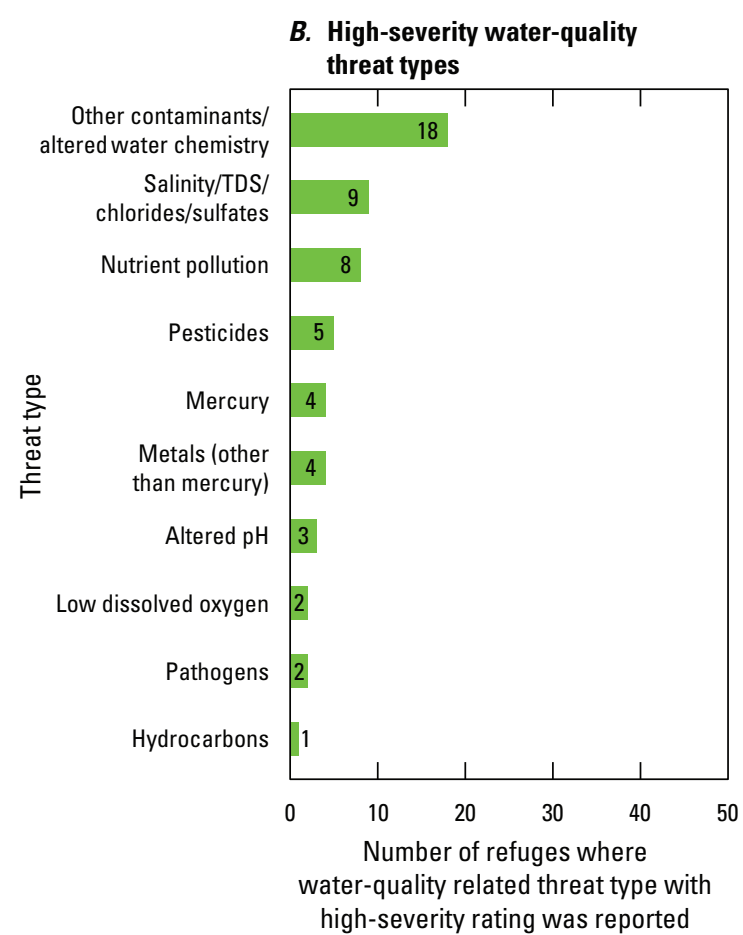

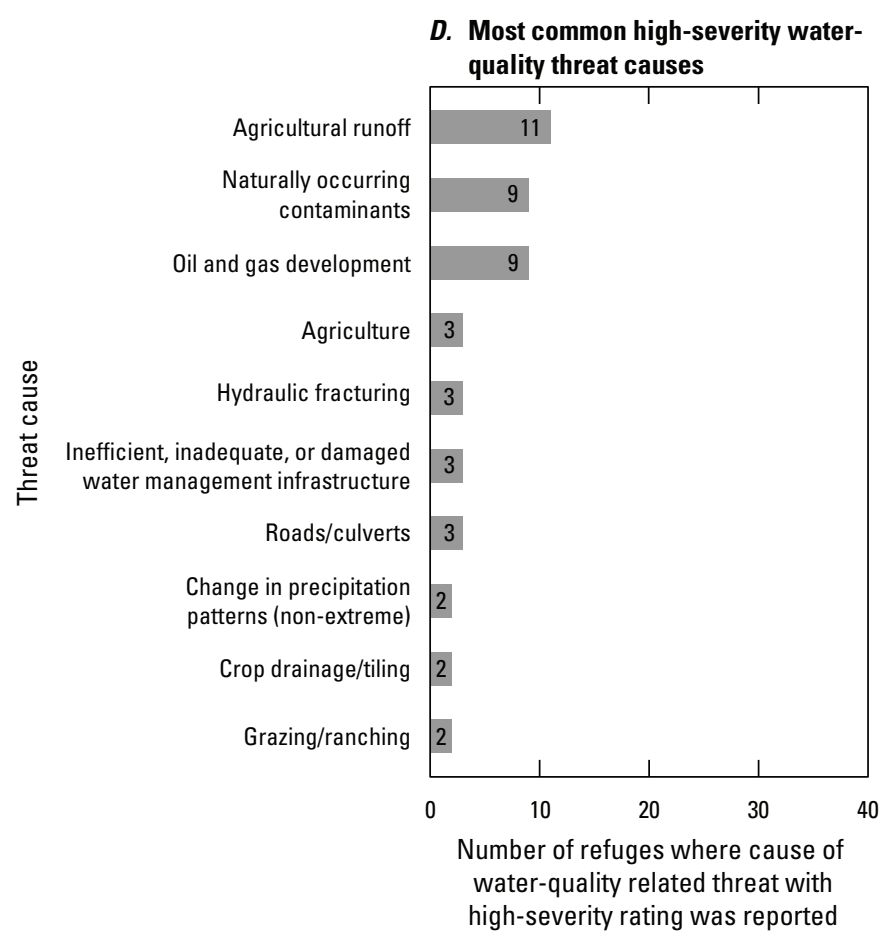

Figure 5. $A$, the 10 most common water-quality threat types; $B$, the 10 most common high-severity water-quality threat types; $C$, the 10 most common causes of water-quality threats; and $D$, the 10 most common causes of high-severity water-quality threats on U.S. Fish and Wildlife Service National Wildlife Refuges in the Legacy Mountain-Prairie Region and the number of refuges where each water-quality threat type and cause were reported (TDS, total dissolved solids. Number in bar represents the number of refuges). 

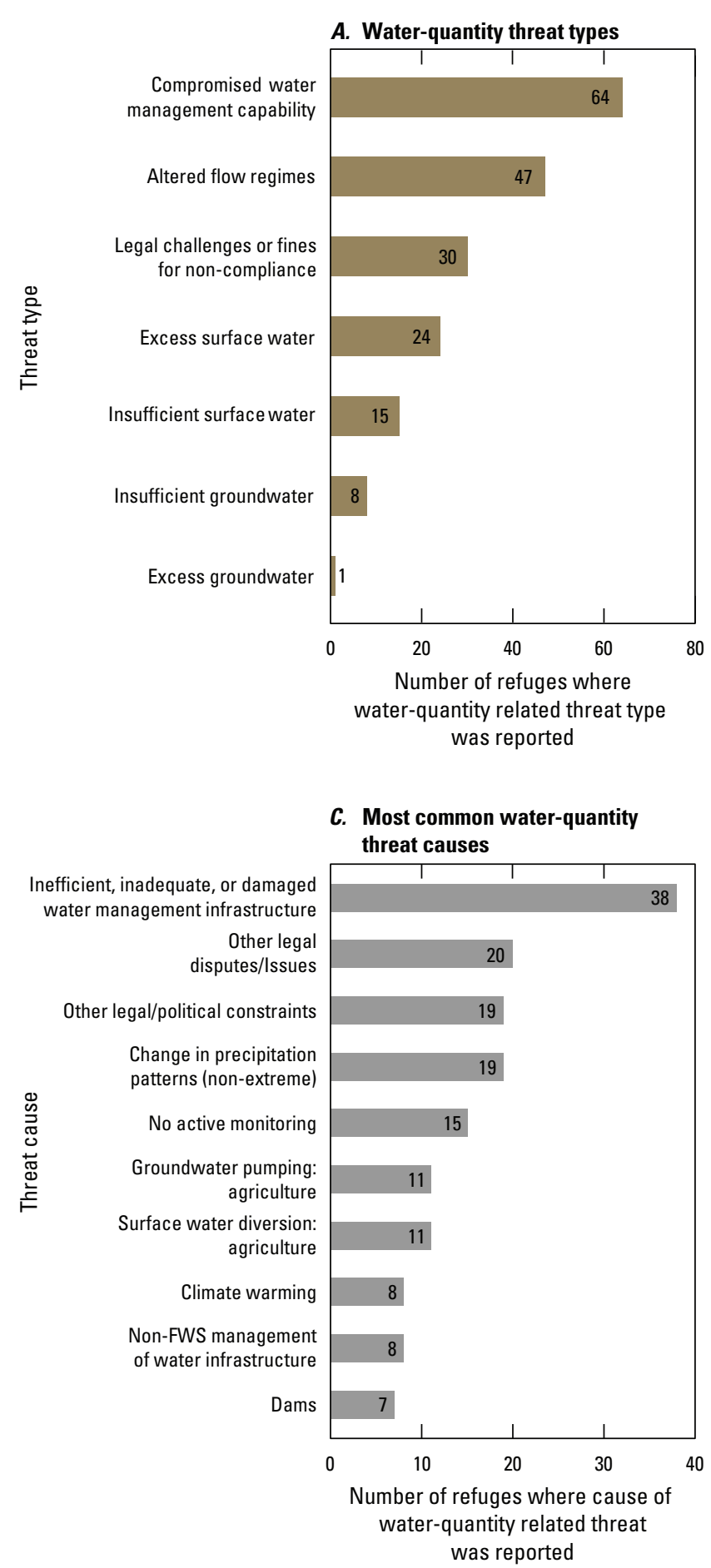

B. High-severity water-quantity threat types

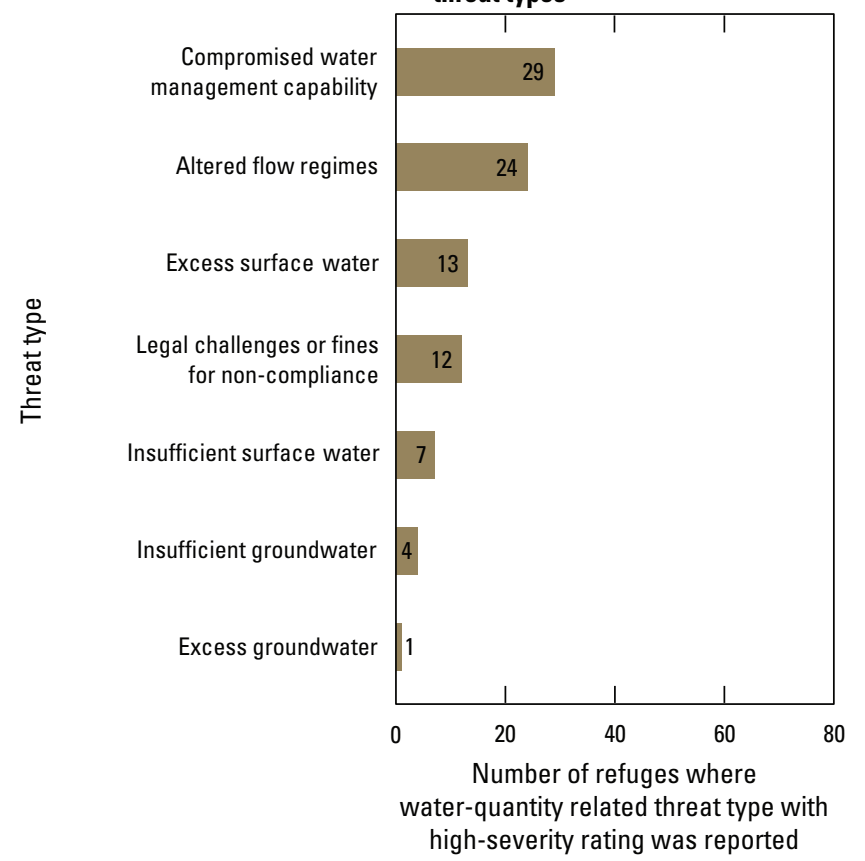

D. Most common high-severity waterquantity threat causes

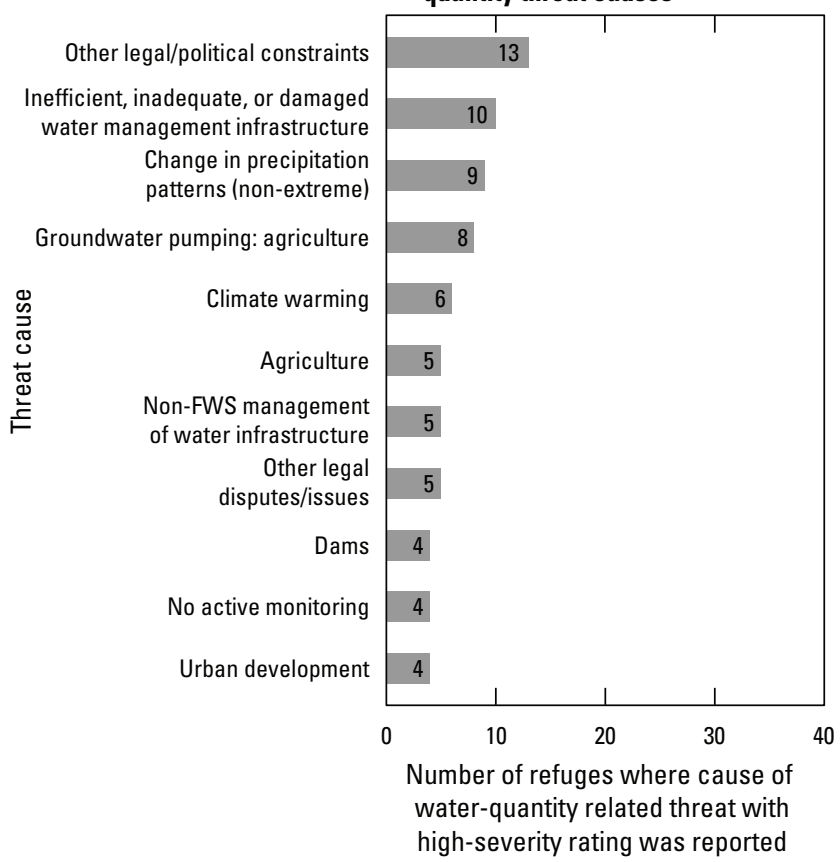

Figure 6. $A$, water-quantity threat types; $B$, high-severity water-quantity threat types; $C$, the 10 most common causes of water-quantity threats; and $D$, the 11 most common causes of high-severity water-quantity threats on U.S. Fish and Wildlife Service (FWS) National Wildlife Refuges in the Legacy Mountain-Prairie Region and the number of refuges where each water-quantity threat type and cause were reported (Number in bar represents the number of refuges). 

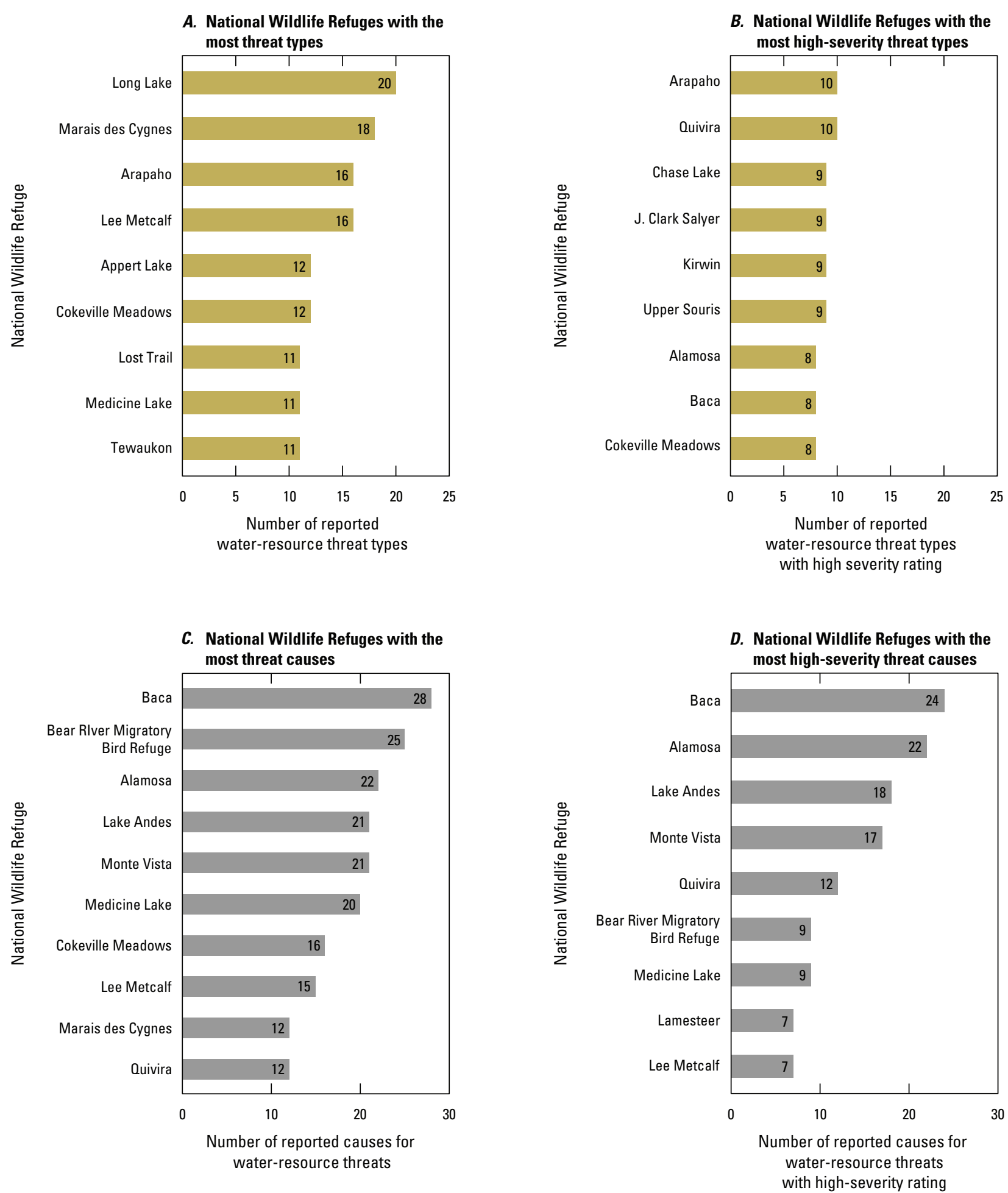

Figure 7. National Wildlife Refuges in the U.S. Fish and Wildlife Service Legacy Mountain-Prairie Region with the most $A$, water-resource threat types; $B$, high-severity water-resource threat types; $C$, causes of water-resource threats; and $D$, causes of high-severity water-resource threats (Number in bar represents the number of threat types or causes). 


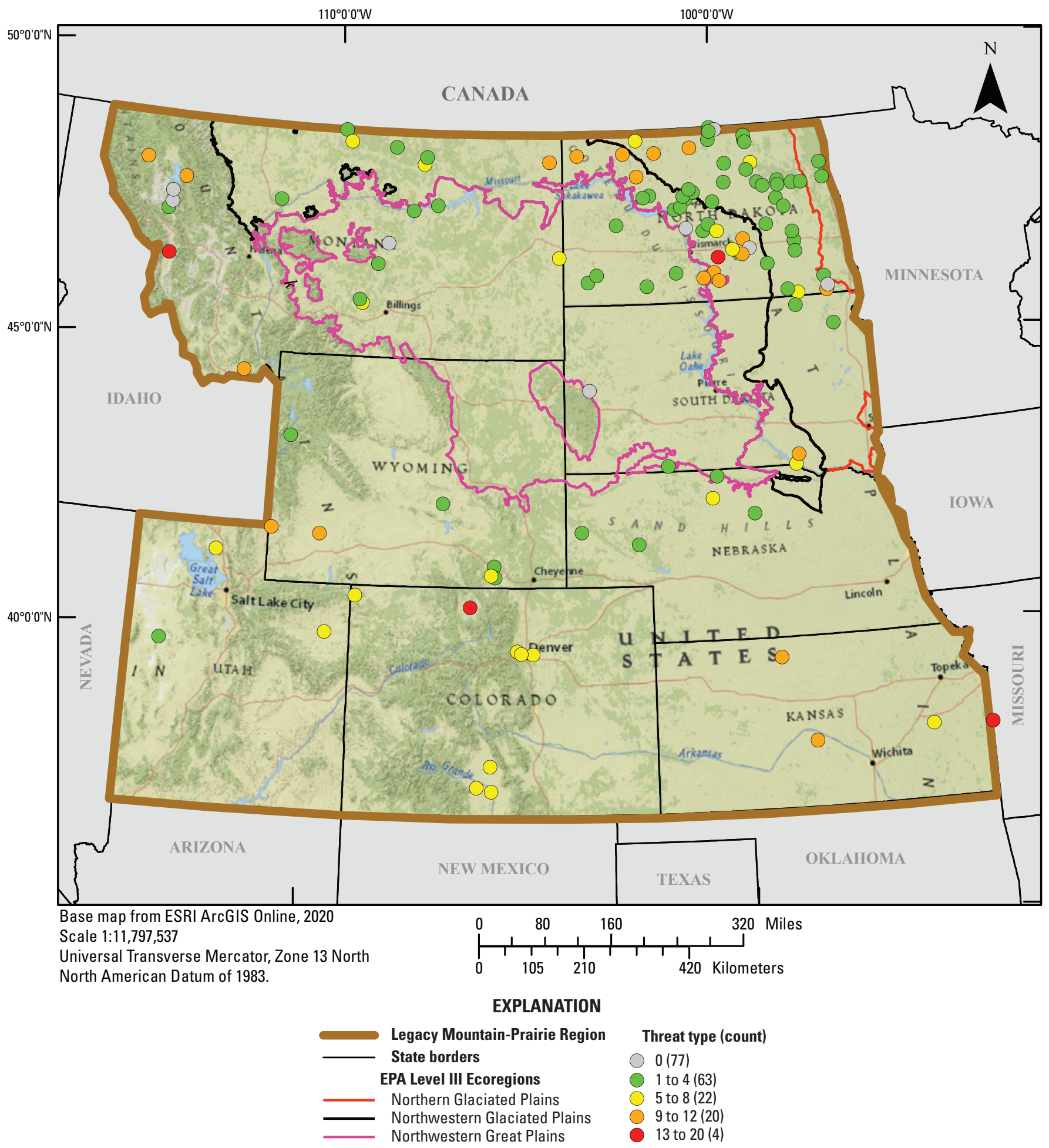

Figure 8. Count of water-resource threat types on National Wildlife Refuges in the U.S. Fish and Wildlife Service Legacy Mountain-Prairie Region (EPA, U.S. Environmental Protection Agency). 


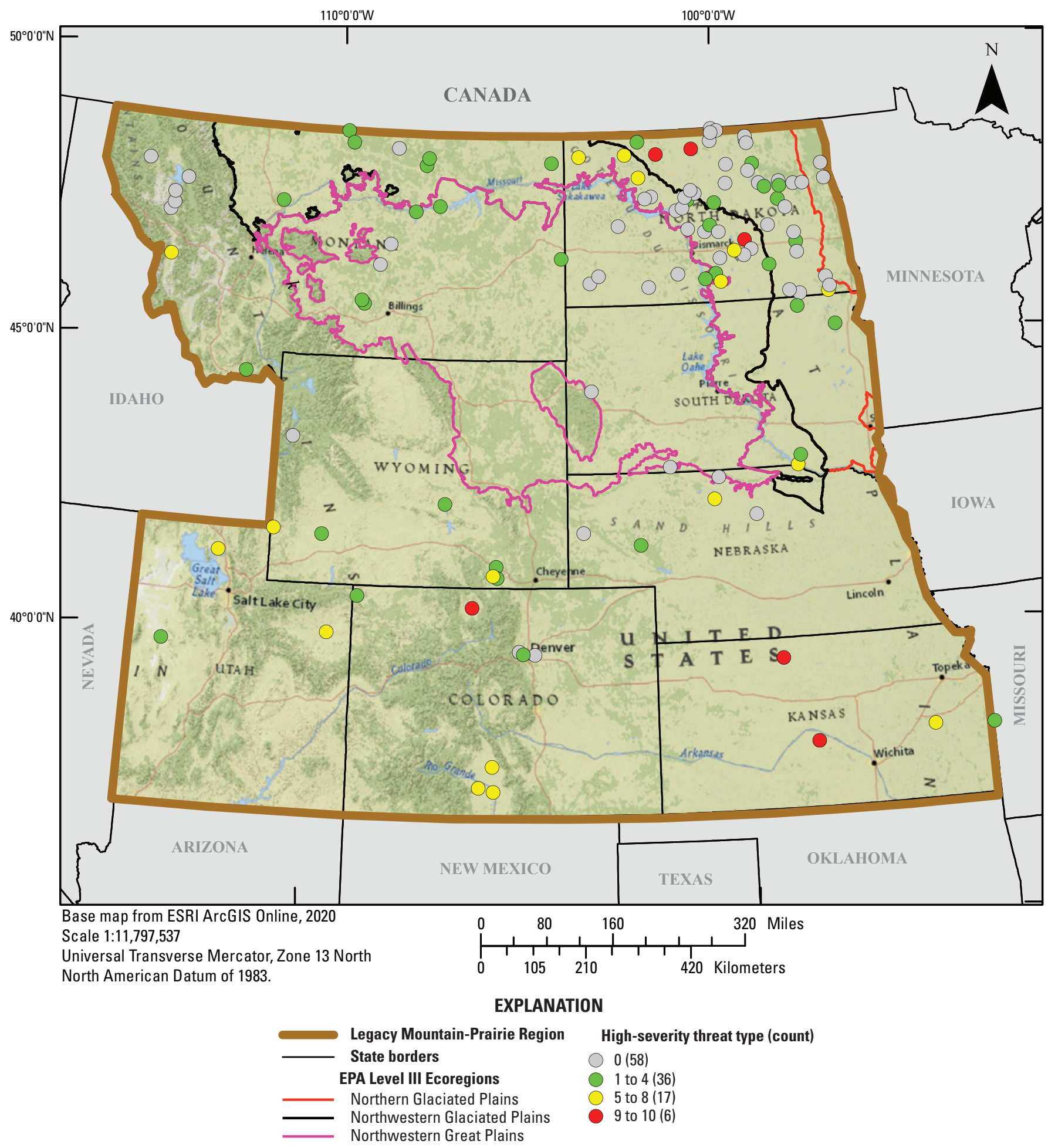

Figure 9. Count of high-severity water-resource threat types on National Wildlife Refuges in the U.S. Fish and Wildlife Service Legacy Mountain-Prairie Region (EPA, U.S. Environmental Protection Agency). 
related to water quality (altered $\mathrm{pH}$, hydrocarbons, metals, other contaminants/altered water chemistry, and salts). Half of the high-severity occurrences at the refuge were under the control of the FWS (FWS, 2107a). At the Quivira NWR, half of the high-severity threat types were related to water quantity (altered flow; compromised water management capability; insufficient groundwater and surface water; legal challenges; and fines for non-compliance with water policy, law, or regulation), and only 2 of the 10 high-severity threat occurrences were under the control of the FWS alone (FWS, 2017a).

As stated previously, there were a total of 72 unique causes of threats among refuges (table 4). Among individual refuges, Baca NWR had the most causes of threats, with 28 unique causes and 24 unique causes of high-severity threats (figs. $7 C$ and 7D). Alamosa, Lake Andes, and Monte Vista NWRs were among the top five refuges with the most causes of overall threats and the most causes for high-severity threats. Most causes of threats at Alamosa, Baca, and Monte Vista NWRs were related to climate, precipitation, and agricultural activities (FWS, 2017a). Southern Colorado, where the three refuges are located, has experienced drought conditions for most years since 2000 (Striffler, 2013; Williams and others, 2020). Many causes of threats at Lake Andes NWR in southeast South Dakota were also related to climate, precipitation, and agriculture (FWS, 2017a).

\section{States}

Among the 8 states in the LMPR, the most water-resource threat types were in North Dakota (26), Montana (24), and Colorado (23), and the greatest percentages of high-severity threat types were in Utah (80 percent), Kansas (67 percent), and Colorado (65 percent) (table 7). The most causes of water-resource threats were in Colorado (43), Montana (43), and North Dakota (36) (table 7). The greatest percentages of causes for high-severity threats were in Colorado (72 percent), Kansas (68 percent), and North and South Dakota (67 percent each) (table 7).

Each state had compromised water management capability and (or) other contaminants/altered water chemistry among their top 3 threat types and had compromised water management capability, altered flow regimes, and (or) habitat shifting/ alteration among their top 3 high-severity threat types (FWS, 2017a). The top overall threat causes for states in the LMPR were invasive species (Kansas, Montana, Nebraska, South Dakota, Utah, and Wyoming); inefficient, inadequate, or damaged water management infrastructure (Colorado, Montana, North Dakota, South Dakota, Utah), and agricultural runoff (Kansas, North Dakota, Utah, and Wyoming) (figs. 1.4-1.6). The top causes of high-severity threats in these states were invasive species (Kansas, Nebraska, North Dakota, South Dakota, Utah, and Wyoming), other legal/political constraints (Colorado, Kansas, North Dakota, Utah, and Wyoming), agricultural runoff (Kansas, Montana, Utah, and Wyoming), and groundwater pumping for agriculture (Colorado, North Dakota, Utah, and Wyoming) (FWS, 2017a).

\section{Ecoregions}

The LMPR refuges are represented by 15 of 16 EPA Level III ecoregions labelled on figure 2 (table 1.1). Most ecoregions (12 of 15) have 7 or fewer refuges within their boundaries. The Northern Glaciated Plains, Northwestern Glaciated Plains, or Northwestern Great Plains ecoregions each contain 15 or more refuges (fig. 2). The comparison of threat types and needs among the ecoregions that this report presents was restricted to these three ecoregions. Of the 4 most common threat types for the Northern Glaciated Plains ecoregion, 3 were unique to that ecoregion and included altered flow regimes, excess surface water, and sedimentation (table 8 ). Common causes for the threats in the Northern Glaciated Plains were related to infrastructure (crop drainage/tiling; dams; drainage ditches; and

Table 7. States in the U.S. Fish and Wildlife Service Legacy Mountain-Prairie Region and the number of water-resource threat types and causes and percentage of high-severity threat types and causes at National Wildlife Refuges in each state.

[No., Number]

\begin{tabular}{lcccc}
\hline \multicolumn{1}{c}{$\begin{array}{c}\text { State } \\
\text { (No. of refuges) }\end{array}$} & $\begin{array}{c}\text { No. of unique } \\
\text { threat types }\end{array}$ & $\begin{array}{c}\text { Percentage of unique threat } \\
\text { types with high-severity } \\
\text { rating }\end{array}$ & $\begin{array}{c}\text { No. of unique } \\
\text { threat causes }\end{array}$ & $\begin{array}{c}\text { Percentage of unique threat } \\
\text { causes of threats with high- } \\
\text { severity rating }\end{array}$ \\
\hline Colorado (8) & 23 & 65 & 43 & 72 \\
\hline Kansas (4) & 21 & 67 & 22 & 68 \\
\hline Montana (21) & 24 & 21 & 43 & 26 \\
\hline Nebraska (5) & 8 & 62 & 7 & 46 \\
\hline North Dakota (63) & 26 & 46 & 24 & 67 \\
\hline South Dakota (6) & 17 & 53 & 32 & 67 \\
\hline Utah (3) & 10 & 80 & 28 & 53 \\
Wyoming (7) & 19 & 47 & 61 \\
\hline
\end{tabular}


Table 8. Characteristics of U.S. Environmental Protection Agency (EPA) Northern Glaciated Plains, Northwestern Glaciated Plains, and Northwestern Great Plains Level III Ecoregions, and the most common water-resource threat types on U.S. Fish and Wildlife National Wildlife Refuges in each of the three ecoregions within the Legacy Mountain-Prairie Region.

[Number in parentheses is a count of refuges in the ecoregion or a count of refuges reporting the common threat types. Count of refuges does not include refuges in more than one EPA Level III Ecoregion. The ecoregion characteristics are from Bryce and others (1996) and Woods and others (2002). The threat types and number of refuges with the threat are from the Environmental Conservation Online System (U.S. Fish and Wildlife Service, 2017a)]

\begin{tabular}{|c|c|c|c|c|}
\hline \multirow{2}{*}{$\begin{array}{l}\text { EPA Level III } \\
\text { ecoregion }\end{array}$} & \multirow[b]{2}{*}{ Level III Ecoregion characteristics } & \multicolumn{3}{|c|}{ Water-resource threat types } \\
\hline & & $\begin{array}{l}\text { 1st most common } \\
\text { threat type }\end{array}$ & $\begin{array}{l}\text { 2nd most common } \\
\text { threat type }\end{array}$ & $\begin{array}{l}\text { 3rd most common threat } \\
\text { type }\end{array}$ \\
\hline $\begin{array}{l}\text { Northwestern } \\
\text { Glaciated Plains } \\
\text { (28) }\end{array}$ & $\begin{array}{l}\text { Transitional ecoregion between the } \\
\text { moister dryland farming on the } \\
\text { Northern Glaciated Plains to the } \\
\text { east and the drier farming and cattle } \\
\text { ranching on the Northwestern Great } \\
\text { Plains to the west. The ecoregion } \\
\text { has high concentrations of semi- } \\
\text { permanent and seasonal wetlands. }\end{array}$ & $\begin{array}{l}\text { Habitat shifting/al- } \\
\text { teration (18) }\end{array}$ & Nutrient pollution (16) & $\begin{array}{l}\text { Compromised water man- } \\
\text { agement capability (14) }\end{array}$ \\
\hline $\begin{array}{l}\text { Northwestern Great } \\
\text { Plains (15) }\end{array}$ & $\begin{array}{l}\text { Largely an unglaciated, semiarid, } \\
\text { and rolling plain with ephemeral- } \\
\text { intermittent streams and a few } \\
\text { perennial rivers. Precipitation is } \\
\text { erratic, and there are limited oppor- } \\
\text { tunities for irrigation. Rangeland is } \\
\text { common. Native grasslands occur in } \\
\text { some areas but have been replaced } \\
\text { by spring wheat and alfalfa over } \\
\text { much of the ecoregion. }\end{array}$ & $\begin{array}{l}\text { Compromised water } \\
\text { management capa- } \\
\text { bility (8) }\end{array}$ & Nutrient pollution (8) & $\begin{array}{l}\text { Habitat shifting/alteration } \\
\text { (7), Other contaminants/ } \\
\text { altered water chemistry } \\
\text { (7) }\end{array}$ \\
\hline
\end{tabular}

inadequate, inefficient, or damaged water management infrastructure), changes in precipitation patterns, and agricultural runoff (FWS, 2017a).

The most common threat types in the Northwestern Glaciated Plains ecoregion (which is transitional between the Northern Glaciated Plains and Northwestern Great Plains ecoregions) were also common threat types in the two other ecoregions (table 8). Other contaminants/altered water chemistry was one of the most common threat types only in the Northwestern Great Plains ecoregion (table 8). The top threats in the Northwestern Glaciated Plains were commonly caused by invasive species, agricultural runoff, and legal-related issues (other legal disputes/issues and other legal/political constraints) (FWS, 2017a). The top threats in the Northwestern Great Plains were commonly caused by no active monitoring, agricultural runoff, and invasive species (FWS, 2017a).

\section{Water-Resource Needs}

Equally important as identifying threats to water resources was identifying needs that could be implemented to help mitigate the threats, either within a few years or in the longer term. A total of 637 unique water-resource need occurrences were reported for 114 refuges in the LMRP (table 4, table 1.1). The 637 need occurrences included 62 water-resource need types (table 4). The 11 most common need types were related to 7 of the 8 need categories listed in the WRIA application (fig. $10 \mathrm{~A}$, table 2). Only the category Mapping and Geospatial Data/Analysis was not represented. The most common need type was a WRIA (fig. 10A), which is a reconnaissance-level inventory and assessment of water quantity and quality on refuge lands (Higgins, 2012). As of 2020 , only 28 refuges have completed or are completing the inventory and assessment. The spatial distribution of the top 


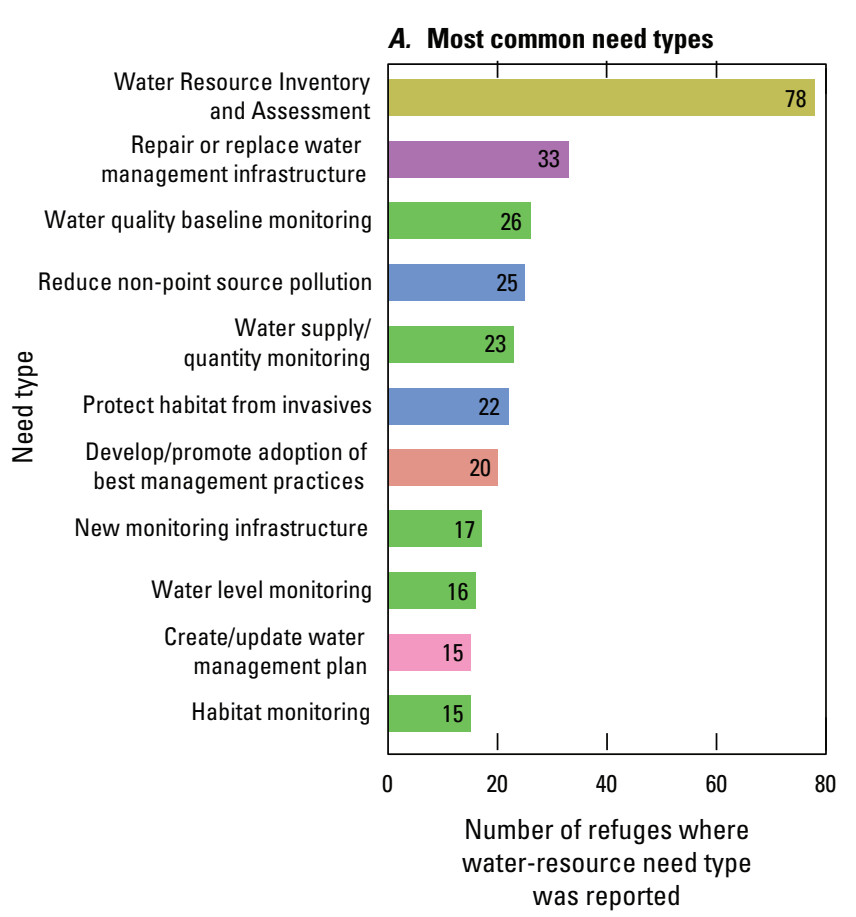

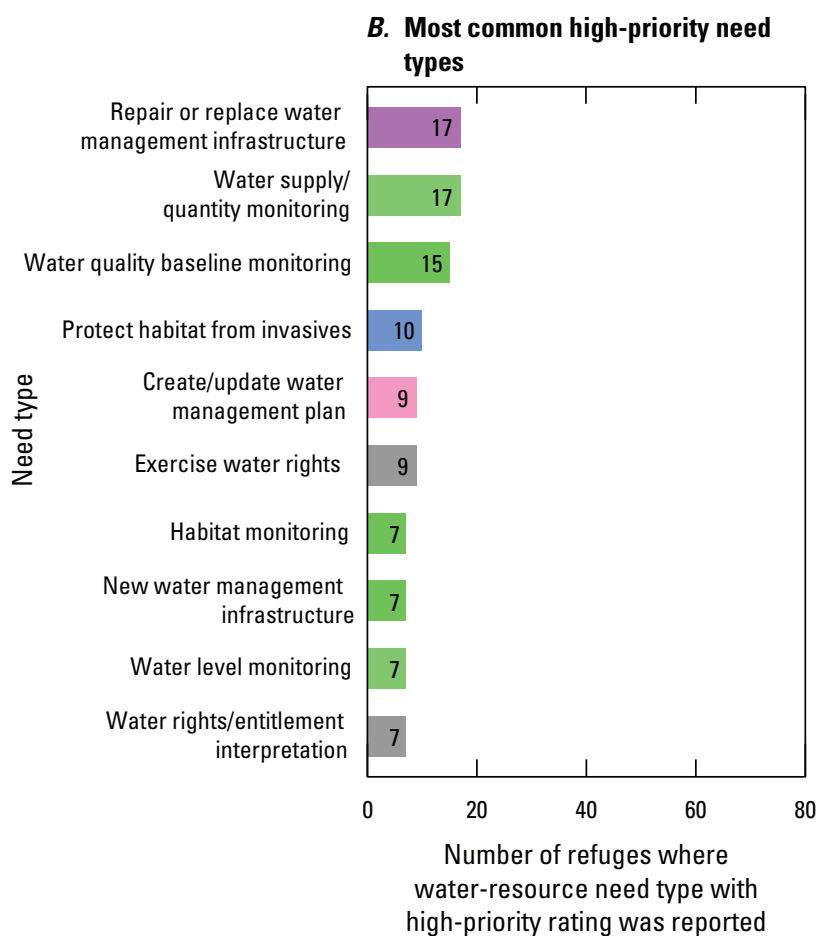

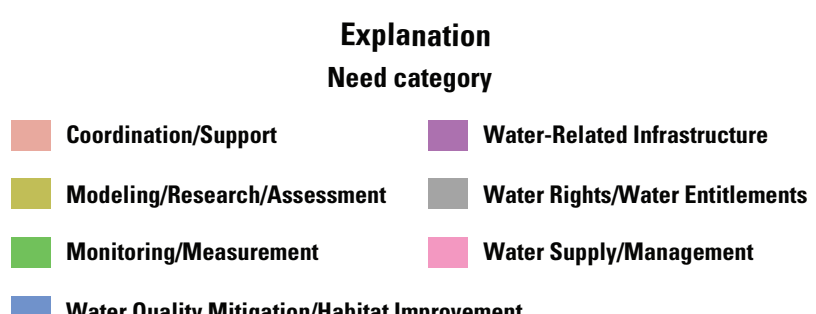

Water Quality Mitigation/Habitat Improvement

15 Number in bar represents number of refuges

Figure 10. $A$, the most common water-resource need types; and $B$, the most common high-priority water-resource need types on U.S. Fish and Wildlife Service National Wildlife Refuges in the Legacy Mountain-Prairie Region and the number of refuges where each need type was reported.

three need types are shown in appendix 1, figures 1.7-1.9. About 68 percent (434 of 637) of the need occurrences could be handled by the FWS alone (table 4).

About 39 percent (248 of 637) of water-resource need occurrences had a high-priority rating and included 54 need types (table 4). One or more of the 54 high-priority need types were reported at 46 refuges (table 4 ), which means that about 40 percent (46 of 114) of refuges had at least 1 need that was necessary to fulfill the conservation mission and waterresource management objectives of a refuge.

The 10 most common high-priority need types were in 5 of 8 need categories (fig. 10B). Only the categories Coordination/Support, Mapping and Geospatial Data/Analysis, and Modeling/Research/Assessment were not represented. A WRIA was a high-priority need for only 8 percent (6 of 78) of refuges with the need type. Most refuges reported a low/ unknown (68 percent, 53 of 78) or moderate (24 percent, 19 of 78) priority need for a WRIA (FWS, 2017a). About 67 percent
(166 of 248) of the high-priority need occurrences could be handled by the FWS alone. Of the 5 most common need types, 2 -repair and replace water management infrastructure and water supply/quantity monitoring - were the most common high-priority need types (figs. $10 \mathrm{~A}$ and 10B). Both need types were frequently related to compromised water management capability. The need for water quality baseline monitoring, the third most common overall need type (26 refuges) and highpriority need type (15 refuges) was not unexpected (fig. $10 \mathrm{~A}$ and $10 B$ ), given that 62 percent (67 of 109) of refuges had one or more water-quality threat types (table 4 ).

The fourth most common need type differed for need types overall and among high-priority need types (figs. $10 \mathrm{~A}$ and $10 B$ ). Reducing nonpoint source pollution, the fourth most common overall need type ( 25 refuges), was directly related to the threat types of nutrient pollution, pesticides, and sedimentation and to the threat cause of agricultural runoff (2017a). Because sources of nonpoint source pollution mostly occur 
outside of refuge boundaries, 23 of 25 refuges reported that outside assistance and (or) cooperation with neighboring landowners would be required to reduce the nonpoint source pollution. Only two refuges reported being able to handle nonpoint source pollution alone. Reducing nonpoint source pollution was a high-priority need type at only four refuges. Instead, protecting habitat from invasive species was the fourth most common high-priority need type (10 refuges) (fig. 10B). Of the 10 refuges, 9 reported that the need to protect habitat could be handled by the FWS alone.

\section{Refuges}

Bear River MBR in northern Utah had 39 unique waterresource need types, the most for any refuge within the LMPR (figs. 11A and 12). For Bear River MBR, about 69 percent (27 of 39) of need types were related to Monitoring/Measurement (9), Water Quality Mitigation/Habitat Improvement (7), WaterRelated Infrastructure (6), and Modeling/Research/Assessment (5). These categories included specific need types such as targeted water quality monitoring, restoring habitat, new water management infrastructure, and water rights mapping (FWS, 2017a). Most (34 of 39) of the needs at Bear River MBR could be handled by the FWS alone (FWS, 2017a). Other refuges with the most needs included Baca NWR (38) and Alamosa and Monte Vista NWRs (36) in southern Colorado, and Lake Andes NWR (28) in southeast South Dakota (figs. $11 \mathrm{~A}$ and 12).

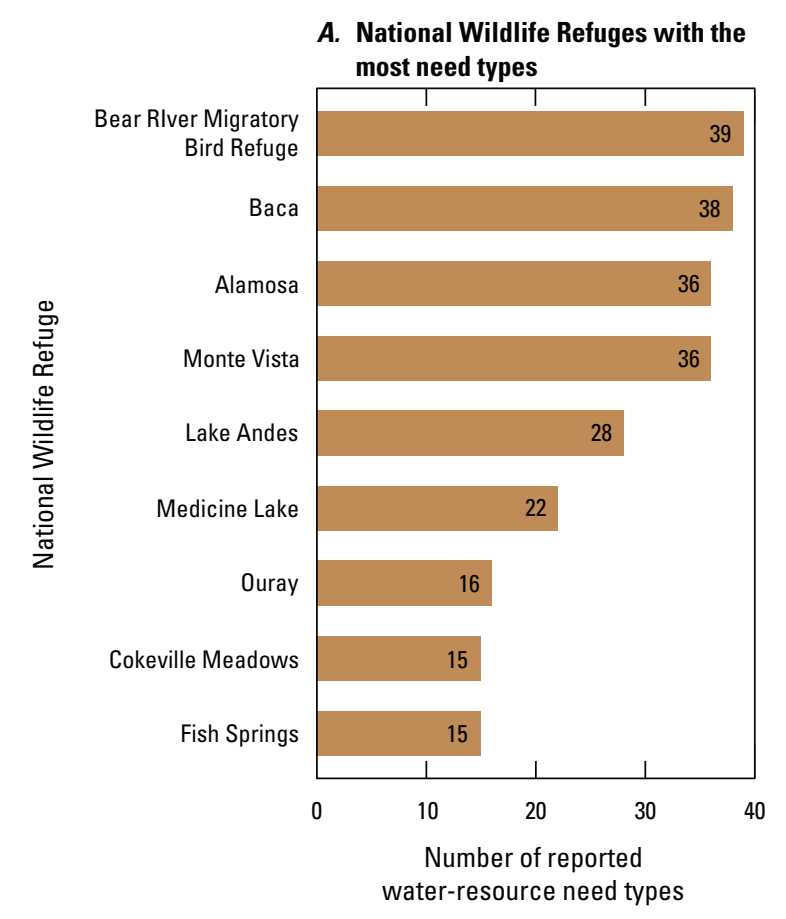

About 40 percent (46 of 114) of refuges with needs had one or more high-priority need types (table 4). Monte Vista NWR in southern Colorado had the greatest number (23) of high-priority need types (figs. $11 \mathrm{~B}$ and 13). Other refuges with the most high-priority need types were Alamosa and Baca NWRs (22 each) and Lake Andes NWR (19) (fig. 11B). As detailed in ECOS (FWS, 2017a), the high-priority need types for Alamosa, Baca, and Monte Vista NWRs were mostly in the need categories of Water Rights/Entitlements (5 or 6 each) and Monitoring/Measurement and Water-Related Infrastructure (4 or 5 each). Specific need types included exercise water rights; monitor water levels, and water supply/quantity monitoring; and repair or replace water management or supply infrastructure. About 61 percent (41 of 67) of high-priority need types at the 3 refuges could be handled by the FWS alone. Highpriority need types for Lake Andes NWR were most commonly in the categories of Water Quality Mitigation/Habitat Improvement (5) and Water-Related Infrastructure (4) and included protect habitat from invasive species, restore floodplain function, and new water management infrastructure. About 63 percent (12 of 19) of high-priority need types at Lake Andes NWR could be handled by the FWS alone.

\section{States}

Among the 8 LMPR states, the most water-resource need types occurred in Utah (47), Colorado (46), and Montana and South Dakota (37 each) (table 9). The greatest percentages

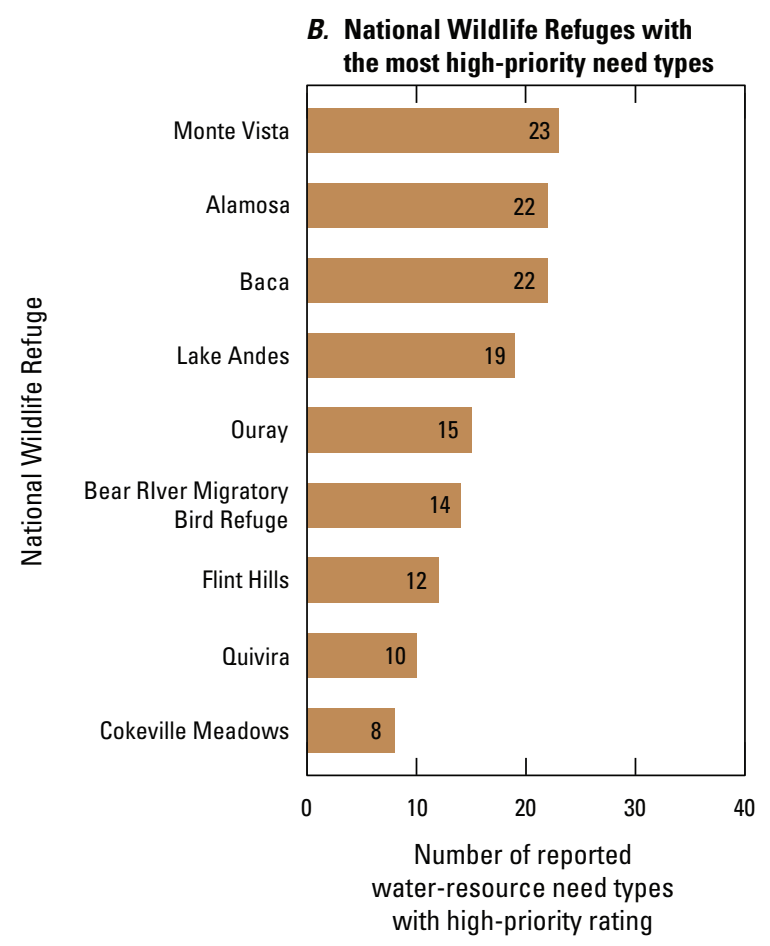

Figure 11. National Wildlife Refuges in the U.S. Fish and Wildlife Service Legacy Mountain-Prairie Region with $A, 15$ or more water-resource need types; and $B, 8$ or more unique high-priority water-resource need types (Number in bar represents the number of need types). 


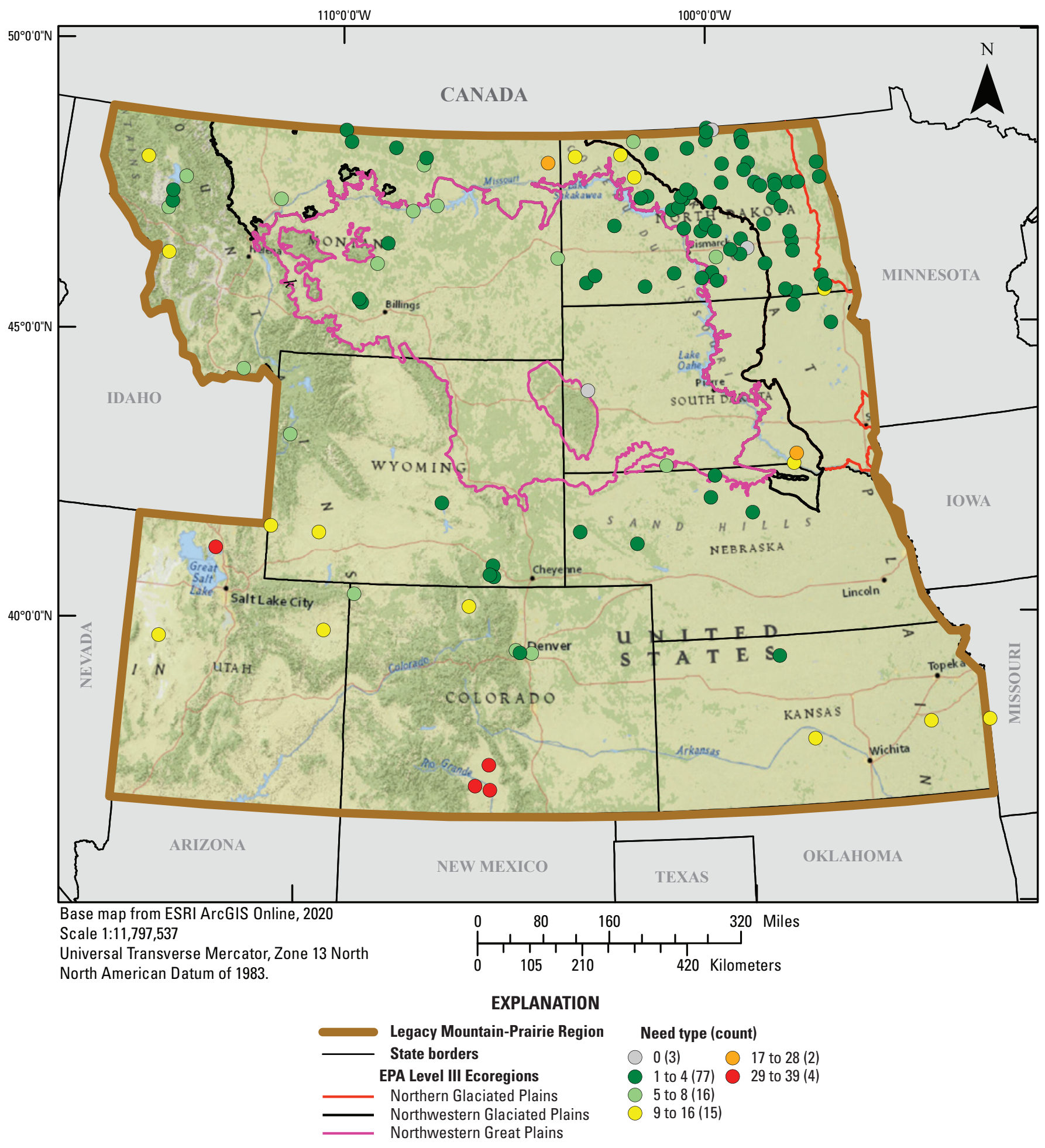

Figure 12. Count of water-resource need types on National Wildlife Refuges in the U.S. Fish and Wildlife Service Legacy Mountain-Prairie Region (EPA, U.S. Environmental Protection Agency). 


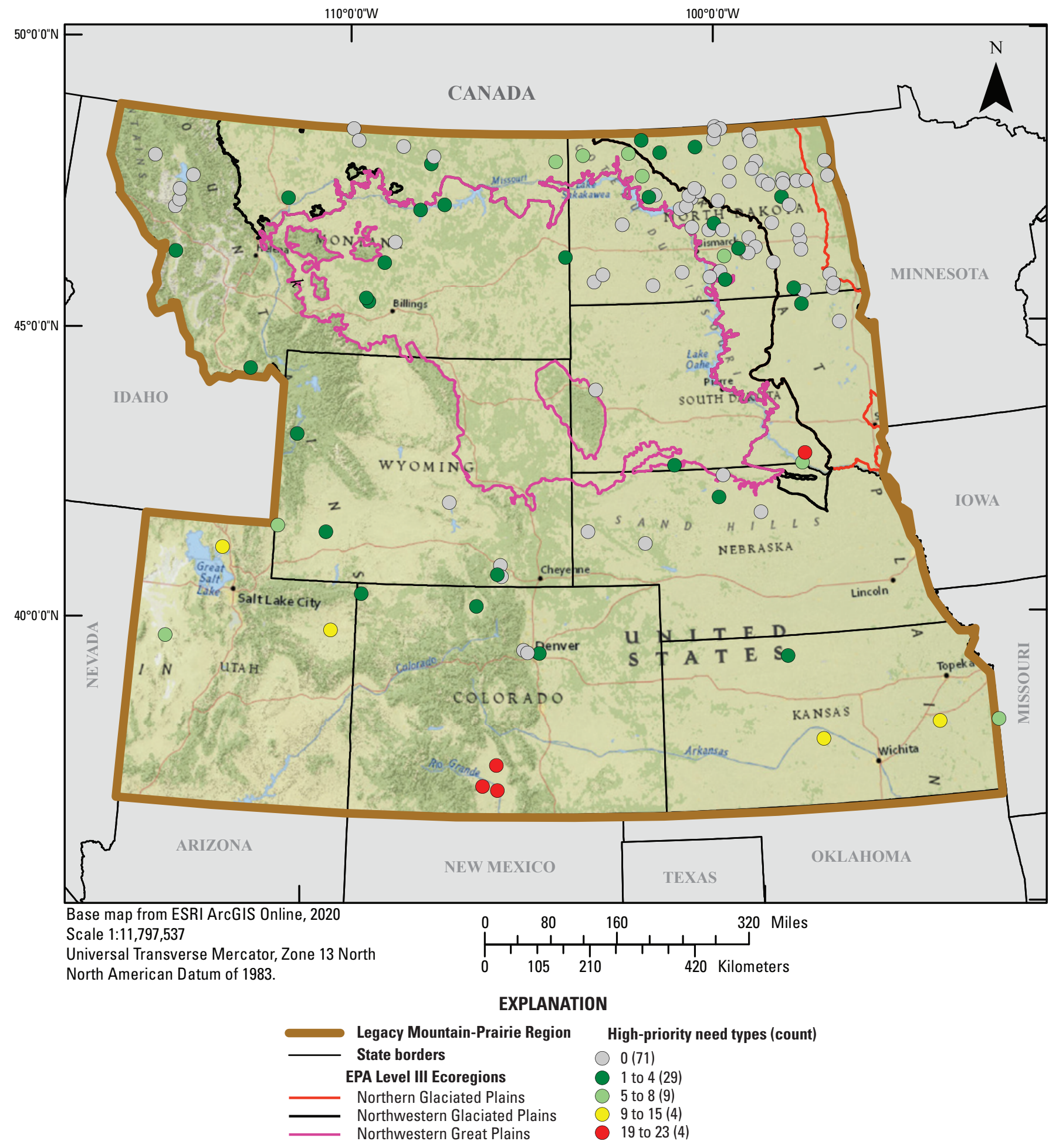

Figure 13. Count of unique water-resource need types with a high-priority rating on National Wildlife Refuges in the U.S. Fish and Wildlife Service Legacy Mountain-Prairie Region (EPA, U.S. Environmental Protection Agency). 
Table 9. States in the U.S. Fish and Wildlife Service Legacy Mountain-Prairie Region and the number of water-resource need types and percentage of high-priority need types at National Wildlife Refuges in each state.

[No, Number]

\begin{tabular}{|c|c|c|}
\hline $\begin{array}{c}\text { State } \\
\text { (No. of refuges) }\end{array}$ & No. of unique need types & $\begin{array}{l}\text { Percentage of unique need types with high-priority } \\
\text { rating }\end{array}$ \\
\hline Colorado (8) & 46 & 54 \\
\hline Montana (21) & 37 & 46 \\
\hline Nebraska (5) & 6 & 17 \\
\hline Utah (3) & 47 & 55 \\
\hline Wyoming (7) & 24 & 46 \\
\hline
\end{tabular}

of high-priority need types were in Kansas ( 87 percent), South Dakota (68 percent), and North Dakota (58 percent) (table 9). The need type of repair or replace water management infrastructure was among the top 3 water-resource need types for 6 states (Colorado, Kansas, Montana, Nebraska, Utah, and Wyoming), and a WRIA need was among the top 3 need types for 5 states (Montana, North Dakota, Nebraska, South Dakota, and Wyoming) (FWS, 2017a). The need type of repair or replace water management infrastructure was also a top 3 high-priority need type for 6 states (Colorado, Kansas, Montana, Nebraska, Utah, and Wyoming), and water supply/ quantity monitoring was one of the top 3 need types for 5 states (Colorado, Montana, North Dakota, South Dakota, and Utah) (FWS, 2017a).

\section{Ecoregions}

A WRIA need was the most common water-resource need type in the Northern Glaciated Plains, Northwestern Glaciated Plains, and Northwestern Great Plains EPA Level III ecoregions and the only top need type in common among the three ecoregions (table 10). Only 11 of the 79 refuges in the 3 ecoregions had completed a WRIA or had a WRIA currently (as of 2020) being completed (FWS, 2017a). Need types common to 2 of the 3 three ecoregions included repair or replacement of water management infrastructure and reduce nonpoint source pollution (table 10). Illustrating the diversity of needs among the 3 ecoregions, 6 need types were present only once in 1 of the 3 ecoregions (table 10).

\section{Synthesis and Ranking}

In the LMPR, almost all refuges (93 percent, 109 of 117) reported a water-resource threat (tables 4 and 1.1). The number of unique threat types varied from 1 threat at 24 refuges to 15 or more threats at 4 refuges (table 1.1). About 54 percent (59 of 109) of refuges reported at least 1 threat severe enough to potentially affect the conservation mission of the refuge (table 4). The number of high-severity threat types ranged from 1 high-severity threat type at 15 refuges to 10 high-severity threat types at 2 refuges. Although the number of water-resource threat types was almost equal for the 3 threat categories, high-severity threat types were more common for the aquatic habitat (36 percent, 84 of 230) and water quantity (39 percent, 90 of 230) threat categories than for the water quality ( 24 percent, 56 of 230) threat category (table 4). About 43 percent (76 of 177) of aquatic habitat and 40 percent ( 75 of 189) of water-quantity threat occurrences could be handled by the FWS alone, whereas few (15 percent, 26 of 174) waterquality threat occurrences were reported as being within the control of the FWS (table 4).

The three most common threat types overall (compromised water management capability, habitat shifting/alteration, and altered flow regimes) were also the most common high-severity threat types (figs. $3 A$ and $3 B$ ). Two of the most common causes of threats (inefficient, inadequate, or damaged water management infrastructure and invasive species) were the most common causes of high-severity threats (figs. $3 C$ and $3 D$ ). For some refuges, a single threat had multiple causes, which could require different mitigation strategies. For example, at Medicine Lake NWR in eastern Montana, the threat of salinity/TDS/chlorides/ sulfate, was reported to have three separate causes: agricultural runoff; inefficient, inadequate, or damaged water management infrastructure; and oil and gas development (FWS, 2017a).

Reported needs for the refuge included reduce nonpoint source pollution, remove infrastructure, and targeted water quality monitoring. Mitigation of the salinity threat for Medicine Lake NWR, and for threats at other refuges, could be complicated because not all the causes could be handled by the FWS alone. Some common threats for refuges that would require outside assistance to address were nutrient pollution (38 refuges), other contaminants/altered water chemistry (35 refuges), and altered flow regimes (32 refuges) (FWS, 2017a). 
Table 10. The most common water-resource need types on U.S. Fish and Wildlife National Wildlife Refuges in the U.S. Environmental Protection Agency (EPA) Northern Glaciated Plains, Northwestern Glaciated Plains, and Northwestern Great Plains Level III Ecoregions within the Legacy Mountain-Prairie Region.

[Number in parentheses is a count of refuges in the ecoregion or a count of refuges reporting the common need types. Count of refuges does not include refuges in more than one Level III Ecoregion. The need types and number of refuges with the need are from the Environmental Conservation Online System (U.S. Fish and Wildlife Service, 2017a)]

\begin{tabular}{|c|c|c|c|}
\hline \multirow[b]{2}{*}{ EPA Ecoregion III } & \multicolumn{3}{|c|}{ Water-resource need types } \\
\hline & 1st most common need type & 2nd most common need type & 3rd most common need type \\
\hline $\begin{array}{l}\text { Northern Glaciated Plains } \\
\text { (36) }\end{array}$ & $\begin{array}{l}\text { Water Resource Inventory and } \\
\text { Assessment (25) }\end{array}$ & $\begin{array}{l}\text { Repair or replace water manage- } \\
\text { ment infrastructure }(6)\end{array}$ & $\begin{array}{l}\text { Climate change vulnerability as- } \\
\text { sessment (5), Create/update water } \\
\text { management plan (5) }\end{array}$ \\
\hline $\begin{array}{l}\text { Northwestern Glaciated } \\
\text { Plains (28) }\end{array}$ & $\begin{array}{l}\text { Water Resource Inventory and } \\
\text { Assessment (20) }\end{array}$ & $\begin{array}{l}\text { Reduce nonpoint source pollution } \\
\text { (11) }\end{array}$ & $\begin{array}{l}\text { Develop or promote adoption of best } \\
\text { management practices (7), Protect } \\
\text { habitat from invasive species (7), } \\
\text { Reduce point-source pollution (7) }\end{array}$ \\
\hline $\begin{array}{l}\text { Northwestern Great } \\
\text { Plains (15) }\end{array}$ & $\begin{array}{l}\text { Water Resource Inventory and } \\
\text { Assessment (13) }\end{array}$ & $\begin{array}{l}\text { Reduce nonpoint source pollution } \\
\text { (7) }\end{array}$ & $\begin{array}{l}\text { Repair or replace water management } \\
\text { infrastructure (5), Water quality } \\
\text { baseline monitoring (5) }\end{array}$ \\
\hline
\end{tabular}

Almost all refuges (97 percent, 114 of 117) reported a water-resource need (tables 4 and 1.1). The number of need types varied, from 1 need type at 26 refuges to 36 or more need types at 4 refuges (table 1.1). Water-resource need types were mostly related to the WRIA application need categories of Modeling/Research/Assessment (23 percent, 148 of 637), Monitoring/Measurement (21 percent, 132 of 637), and Water Quality Mitigation/Habitat Improvement (16 percent, 102 of 637) (FWS, 2017a). About 68 percent (434 of 637) of the need occurrences could be handled by the FWS alone (table 4). Excluding the need for a WRIA, outside assistance would most commonly be required for the Water Quality Mitigation/ Habitat Improvement and Water Rights/Water Entitlements need categories (FWS, 2017a). About 40 percent (46 of 114) of refuges had at least 1 high-priority need type that was necessary to fulfill the conservation mission and water-resource management objectives of the refuge (table 4). The number of high-priority need types ranged from 1 high-priority need type at 9 refuges to 22 or more high-priority need types at 3 refuges. High-priority need types were mostly related to the need categories of Monitoring/Measurement (24 percent, 60 of 248) and Water-Related Infrastructure and Water Rights/Water Entitlements (15 percent each, 38 of 248) (FWS, 2017a). High-priority need types most commonly not under control of the FWS were related to the Water Rights/Water Entitlements need category (FWS, 2017a). For example, at Quivira NWR in Kansas, assistance from the State of Kansas is needed to address water rights impairments at the refuge (FWS, 2017a). Of the top 5 need types, 3 (repair or replace water management infrastructure, water quality baseline monitoring, and water supply/quantity monitoring) were the highest-priority need types (figs. 10A and 10B). Reducing nonpoint source pollution was the most common need that could not be handled by the FWS alone (FWS, 2017a). This need was mostly related to water-quality threats from agricultural runoff that originated outside of refuge boundaries.

The ranking values for refuges calculated from highseverity threats and high-priority needs were used to develop three separate rankings: a ranking of refuges by the most high-severity threat types, a ranking of refuges by the most high-priority needs, and an overall ranking of refuges for conservation efforts to fulfill refuges' statutory purposes. The overall ranking values for refuges were calculated by summing the refuges' high-severity threat ranking number and high-priority need ranking number. A higher overall ranking value can correspond to a greater need for conservation efforts. Refuges with the greatest ranking values of 7-10 for highseverity threat types are shown in figure $14 A$. The next ranking value of 5 was for Bear River MBR and Ouray NWR (FWS, 2017a). Refuges with the greatest ranking values of 8-23 for high-priority needs are shown in figure 14B. The highest overall ranking value of 30 was calculated for Alamosa, Baca, and Monte Vista NWRs (fig. 14C). Other refuges in the top 10 overall ranking had values of 14-22 (fig. 14C). This included Lakes Andes NWR (22), Ouray and Quivira NWRs (20 each), Bear River MBR and Flint Hills NWR (19 each), Cokeville Meadows NWR (16), and Arapaho NWR (14). Some refuges with a high number of high-severity threat types, such as Chase Lake, J. Clark Salyer, Kirwin, and Upper Souris NWRs, had few or 0 need types with a high-priority rating. This disconnect between the number of high-severity threats and high-severity needs could indicate the need for additional study by refuge and DWR staff.

The threats and needs identified in this report can be used to help inform FWS about potential current and future actions to manage and preserve the water resources at refuges in the LMPR. Although most threats (67 percent, 363 of 540) would involve working with outside partnerships for mitigation, 

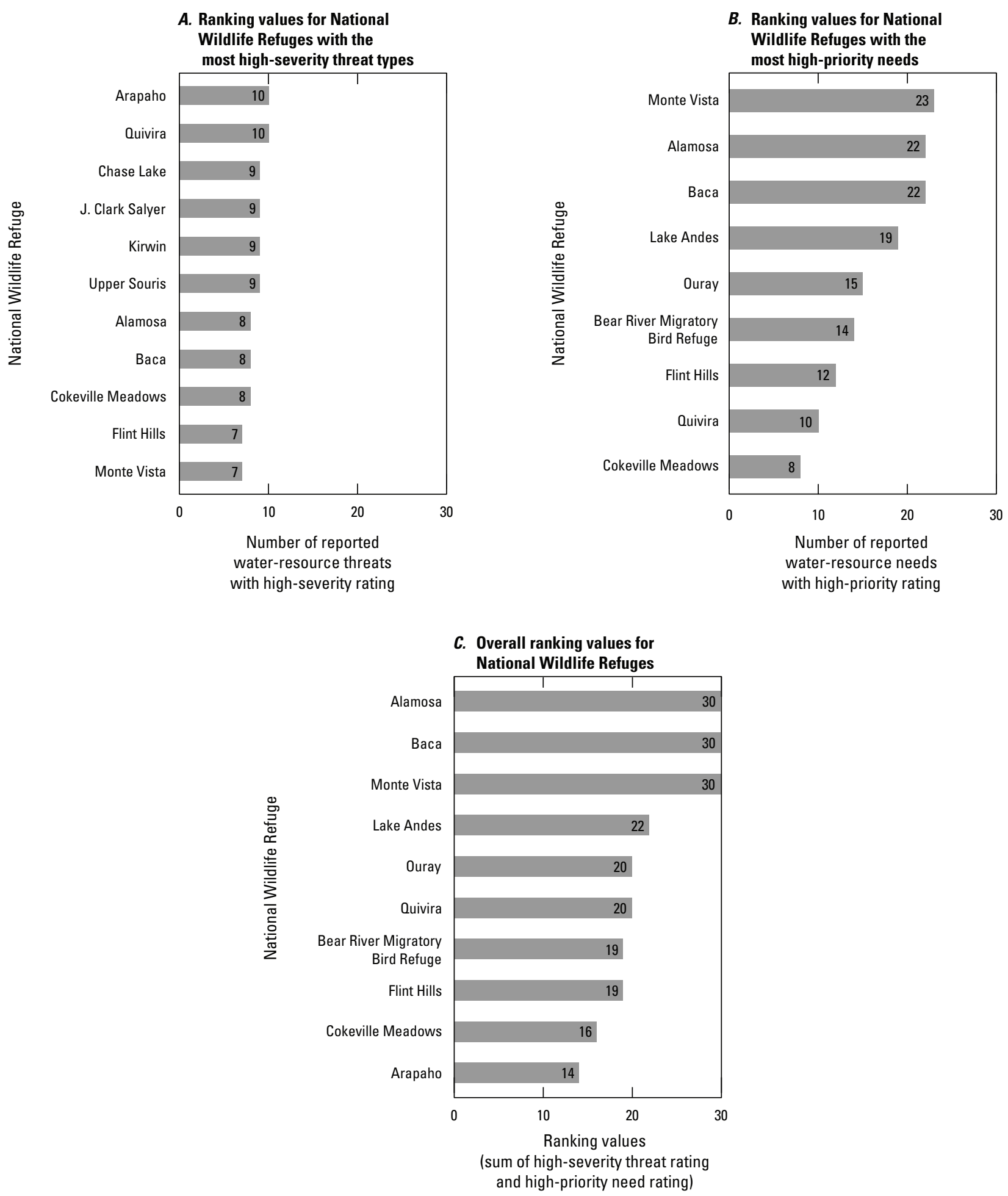

Figure 14. National Wildlife Refuges in the U.S. Fish and Wildlife Service (FWS) Legacy Mountain-Prairie Region with the greatest ranking values for $A$, high-severity water-resource threat types; $B$, high-priority water-resource needs; and $C$, overall ranking values. 
about 33 percent ( 177 of 540 ) of the threats were under the control of the FWS to mitigate (table 4). The threat type most commonly reported as being under control at refuges was compromised water management capability (39 refuges); followed by habitat shifting/alteration (22); altered flow regimes (15); loss/alteration of wetland habitat (14); and legal challenges of fines for non-compliance with water policy, law, or regulation (12) (FWS, 2017a). For threats with a high-severity rating, 37 percent ( 84 of 230) of occurrences were under control of the FWS (table 4). The top five high-severity threat types under control were the same as those for overall threats.

Unlike threats, most need occurrences ( 68 percent, 434 of 637) were under control of the FWS (table 4). The most common need types that could be addressed without outside assistance included a WRIA (60 refuges), repair or replace water management infrastructure (28), water supply/quantity monitoring (21), water quality baseline monitoring (20), and protect habitat from invasive species (19) (FWS, 2017a). Most of the high-priority need occurrences (67 percent, 166 of 248) were also under FWS control (table 4). The top five high-priority need types included most of the common overall needs under FWS control and water level monitoring (FWS, 2017a).

\section{Summary}

In 2019, the U.S. Geological Survey, in cooperation with the U.S. Fish and Wildlife Service (FWS), began a study to complete the compilation and quality assurance of waterresource threats and needs data for the 117 National Wildlife Refuges (NWRs) in the FWS Legacy Mountain-Prairie Region (LMPR) and to characterize the threats and needs of each refuge and of the LMPR itself. The LMPR encompasses the states of Colorado, Kansas, Montana, Nebraska, North Dakota, South Dakota, Utah, and Wyoming. Included in this report are the compilation and quality assurance of current (April 2020) water-resource threats and needs data for refuges in the LMRP and the statistical, graphical, and spatial characterization of the threats and needs dataset. This includes the ranking and prioritizing of threats, threat causes, and needs by number of occurrences in the LMPR as a whole and by refuges, states, and select U.S. Environmental Protection Agency (EPA) Level III Ecoregions. To compile and quality assure the threats and needs data, existing data were downloaded from the FWS Environmental Conservation Online System Water Resource Inventory and Assessment (WRIA) application, publications and websites were searched for additional threats and needs, and refuge staff and staff of the LMPR Division of Water Resources were conferred with.

A total of 540 unique threat occurrences spread among 29 threat types were identified for 109 refuges. No threats were identified for eight refuges. About 43 percent of the threat occurrences had a high-severity threat rating. These highseverity threats were reported for 59 refuges. About 54 percent of refuges had at least one threat severe enough to potentially threaten the conservation mission of the refuge. Of the 10 most common threat types, 8 were also among the most common high-severity threat types. There were 72 different causes for the water-resource threats. About 83 percent of all threat causes were associated with high-severity threats.

The three most common threat types overall and the most common severe threat types were compromised water management capability, habitat shifting/alteration, and altered flow regimes. Compromised water management capability was most commonly caused by inefficient, inadequate, or damaged water management infrastructure for overall threats and by legal/ political constraints for high-severity threats. Habitat shifting/ alteration was most commonly caused by invasive species, for both overall threats and high-severity threats. Altered flow regimes was most commonly caused by change in non-extreme precipitation patterns for overall threats and pumping of groundwater or agriculture in the case of high-severity threats.

Refuges with the greatest number of water-resource threat types included Long Lake (20), Marais des Cygnes (18) and Arapaho and Lee Metcalf (16 each) NWRs. About 54 percent of refuges with threats also had high-severity threats. Arapaho and Quivira NWRs each had 10 highseverity threat types, the maximum number of high-severity threats for LMPR refuges.

Among the eight LMPR states, the most water-resource threat types occurred in North Dakota, Montana, and Colorado, and the percentages of high-severity threat types were greatest in Utah, Kansas, and Colorado. All states had compromised water management capability and (or) other contaminants/altered water chemistry among their top 3 threat types and compromised water management capability, altered flow regimes, and (or) habitat/shifting alteration among their top 3 high-severity threat types.

Threats and needs data for refuges in the Northern Glaciated Plains, Northwestern Glaciated Plains, and Northwestern Great Plains EPA Level III ecoregions were compared. Of the 4 most common threat types for the Northern Glaciated Plains ecoregion, 3 were unique to that ecoregion. The most common threat types in the Northwestern Glaciated Plains ecoregion were also common threats in the two other ecoregions. Other contaminants/altered water chemistry was a most common threat type only in the Northwestern Great Plains ecoregion.

A total of 637 unique water-resource need occurrences were identified for 114 refuges, which included 62 need types. No needs were reported for three refuges. The most common need type, a WRIA need, was reported for 78 refuges. About 39 percent of water-resource needs had a high-priority rating. This included 54 need types at 46 refuges. About 40 percent of refuges had at least 1 need type that was necessary to fulfill the conservation mission and water-resource management objectives of a refuge. Two of the most common need types, repair and replace water management infrastructure and water supply/quantity monitoring, were the most common high-priority need types. Water quality baseline monitoring was the third most common overall need type and high-priority need type. 
Bear River Migratory Bird Refuge had the most (39) water-resource need types among refuges in the LMPR. Other refuges with the greatest number of need types included Baca NWR (38), Alamosa and Monte Vista NWRs (36 each), and Lake Andes NWR (28). Of the 114 refuges with waterresource needs, 46 had high-priority needs. Monte Vista NWR had the most (23) high-priority need types. Alamosa (22), Baca (22), and Lake Andes (19) NWRs were also among the top 4 refuges with high-priority need types.

The need type of repair or replace water management infrastructure was among the top 3 water-resource need types for 6 states in the LMPR, and a WRIA need was among the top 3 need types for 5 states. The need type of repair or replace water management infrastructure was also one of the top 3 high-priority need types for 6 states, and water supply/quantity monitoring was one of the top 3 need types for 5 states.

A WRIA need was the most common water-resource need type in the Northern Glaciated Plains, Northwestern Glaciated Plains, and Northwestern Great Plains EPA Level

III Ecoregions and the only need type in common among the 3 ecoregions. Other need types common to 2 of the 3 ecoregions included repair or replacement of water management infrastructure and reduce nonpoint source pollution.

An overall ranking scheme was developed to identify refuges that have the highest-ranking priority for conservation efforts to fulfill refuges' statutory purposes. The count of occurrences of high-severity threats and high-priority needs were summed to determine the overall ranking value for a refuge. A higher overall ranking value can correspond to a greater need for conservation efforts. The 10 refuges with the highest overall ranking values (sum of high-severity threat counts and high-priority need counts), in order of ranking from higher to lower, were Alamosa, Baca, and Monte Vista NWRs (tied for highest); Lake Andes NWR, Ouray and Quivira NWRs, Bear River Migratory Bird Refuge and Flint Hills NWR, Cokeville Meadows NWR, and Arapaho NWR.

About 33 percent of threat occurrences were reported as under the control of the FWS to mitigate, most commonly the threat types of compromised water management capability; habitat shifting/alteration; altered flow regimes; loss/ alteration of wetland habitat; and legal challenges of fines for non-compliance with water policy, law, or regulation. These 5 threat types were also the most common of the 37 percent of high-severity threat occurrences under FWS control at NWRs in the LMPR. A total of 68 percent of need occurrences were under the control of the FWS, most commonly the need types of a WRIA, repair or replace water management infrastructure, water supply/quantity monitoring, water quality baseline monitoring, and protect habitat from invasive species. Most (67 percent) of high-priority need occurrences were also under the control of the FWS. These high-priority need occurrences included most of the common overall need types under FWS control and water level monitoring.

\section{References Cited}

Bryce, S.A., Omernik, J.M., Pater, D.E., Ulmer, M., Schaar, J., Freeouf, J., Johnson, R., Kuck, P., and Azevedo, S.H., 1996, Ecoregions of North Dakota and South Dakota (2 sided color poster with map, descriptive text, summary tables, and photographs): Reston, Va., U.S. Geological Survey [map scale $1: 1,500,000]$.

Esri, 2020, ArcGIS - The mapping and analytics platform: Redlands, Calif., ArcGIS, accessed September 2019, at https:/www.esri.com/en-us/arcgis/about-arcgis/overview.

Higgins, M.J., 2012, Water Resource Inventory and Assessment (WRIA) effort: U.S. Fish and Wildlife Service Fact Sheet, 2 p., accessed December 4, 2019, at https://www.fws.gov/refuges/NaturalResourcePC/pdfs/ FY2012_NRPC_WRIA_Fact_Sheet.pdf.

Omernik, J.M., 1987, Ecoregions of the conterminous United States: Annals of the Association of American Geographers, v. 77 , no. 1 , p. $118-125$.

R Core Team, 2020, R-The R project for statistical computing: Vienna, Austria, R Foundation for Statistical Computing, accessed February 2020, at https://www.r-project.org/.

Striffler, P.S., 2013, Water Resource Inventory and Assessment-Alamosa National Wildlife Refuge: Lakewood, Colo., U.S. Fish and Wildlife Service, 147 p.

Striffler, P.S., and Shafer, C.A., 2016, Water Resource Inventory and Assessment-Ouray National Wildlife Refuge and Ouray National Fish Hatchery: Lakewood, Colo., U.S. Fish and Wildlife Service, 89 p.

U.S. Environmental Protection Agency [EPA], 2018, Level III and IV ecoregions of the continental United States: U.S. Environmental Protection Agency, accessed July 2019, at https://www.epa.gov/eco-research/level-iii-and-ivecoregions-continental-united-states.

U.S. Fish and Wildlife Service [FWS], 2000, Flint Hills National Wildlife Refuge Comprehensive Conservation Plan: U.S. Fish and Wildlife Service, 123 p.

U.S. Fish and Wildlife Service [FWS], 2006, Comprehensive Conservation Plan-North Dakota limited-interest National Wildlife Refuges: Lakewood, Colo., U.S. Fish and Wildlife Service, 123 p., accessed January 23, 2020, at https://www.fws.gov/mountain-prairie/refuges/ completedPlanPDFs_A-E/nd_lir_2007_ccpfinal_all.pdf.

U.S. Fish and Wildlife Service [FWS], 2013, Long Lake National Wildlife Refuge: U.S. Fish and Wildlife Service, accessed March 13, 2020, at https://www.fws.gov/refuge/ Long_Lake/about.html. 
U.S. Fish and Wildlife Service [FWS], 2017a, ECOSEnvironmental Conservation Online System: U.S. Fish and Wildlife Service, accessed May 20, 2020, at https://www.fws.gov/southeast/conservation-tools/ environmental-conservation-online-system/.

U.S. Fish and Wildlife Service [FWS], 2017b, National Wildlife Refuge System: U.S. Fish and Wildlife Service, accessed November 3, 2020, at https://www.fws.gov/ refuges/realty/faq.html.

U.S. Fish and Wildlife Service [FWS], 2019a, U.S. Fish and Wildlife Service-About us: U.S. Fish and Wildlife Service, accessed April 9, 2019, at https://www.fws.gov/ refuges/about/.

U.S. Fish and Wildlife Service [FWS], 2019b, MountainPrairie Region: U.S. Fish and Wildlife Service, accessed April 9, 2019, at https://www.fws.gov/mountain-prairie/ aboutus.php.
U.S. Fish and Wildlife Service [FWS], 2020, ServCat-Fish and Wildlife Service Catalog: U.S. Fish and Wildlife Service, accessed June 23, 2020, at https://ecos.fws.gov/ServCat/.

Williams, A.P., Cook, E.R., Smerdon, J.E., Cook, B.I., Abatzoglou, J.T., Bolles, Kasey, Baek, S.H., Badger, A.M., and Livneh, Ben, 2020, Large contribution from anthropogenic warming to an emerging North American megadrought: Science, v. 368, no. 6488, p. 314-318, accessed August 28, 2020, at https://doi.org/10.1126/science.aaz9600.

Woods, A.J., Omernik, J.M., Nesser, J.A., Shelden, James, Comstock, J.A., and Azevedo, S.H., 2002, Ecoregions of Montana (color poster with map, descriptive text, summary tables, and photographs; $2 \mathrm{~d}$ ed.): U.S. Geological Survey, [map scale 1:1,500,000].
Publishing support provided by the Science Publishing Network, Denver Publishing Service Center For more information concerning the research in this report, contact the

Director, USGS Colorado Water Science Center

Box 25046, Mail Stop 415

Denver, CO 80225

(303) 236-4882

Or visit the Colorado Water Science Center website at

https://www.usgs.gov/centers/co-water 


\section{Appendix 1. Table Listing U.S. Wildlife Fish and Wildlife Service Refuges in the Legacy Mountain-Prairie Region and Maps Showing Severity and Priority Ratings for the Most Common Water-Resource Threat Types and Causes and Water-Resource Need Types}

This appendix includes a table and maps related to U.S. Fish and Wildlife Service National Wildlife Refuges in the Legacy Mountain-Prairie Region (LMPR). The table lists refuges in the LMPR as well as the number of unique threat and needs types for each refuge and sources of the threats and needs data. The maps show refuges in the LMPR and the three most common water-resource threat types, causes of waterresource threats, and water-resource need types and severity and priority ratings. 
Table 1.1. List of U.S. Fish and Wildlife Service National Wildlife Refuges in the Legacy Mountain-Prairie Region, with the number of unique threat and need types for each refuge and sources of threats and needs data.

[fig., figure; EPA, U.S. Environmental Protection Agency; No., Number; ECOS, Environmental Conservation Online System; CO, Colorado; RS, personal communication with National Wildlife Refuge staff; T, threats and needs assessment; W, Water Resources Investigation and Assessment recommendation; LS, U.S. Fish and Wildlife Service Legacy Mountain-Prairie Region Division of Water Resources staff; C, Comprehensive Conservation Plan; nc, no change; KS, Kansas; P, peer-reviewed report or journal article; MT, Montana; nd, no data; ND, North Dakota; O, on-site investigation; I, internet-published data; CAP, Containment Assessment Process or on-site investigation; NE, Nebraska; M, management plan; SD, South Dakota; WY, Wyoming; NWR, National Wildlife Refuge. Designations for origins of data are from U.S. Fish and Wildlife Service, 2017a. See Omernik (1987) for Level III Ecoregion information]

\begin{tabular}{|c|c|c|c|c|c|c|c|c|c|c|}
\hline \multirow[b]{2}{*}{$\begin{array}{c}\text { Site } \\
\text { identifier } \\
\text { (fig. 1) }\end{array}$} & \multirow[b]{2}{*}{$\begin{array}{c}\text { National Wildlife } \\
\text { Refuge }\end{array}$} & \multirow[b]{2}{*}{ State } & \multirow[b]{2}{*}{$\begin{array}{c}\text { Size } \\
\text { (acres) }\end{array}$} & \multirow[b]{2}{*}{$\begin{array}{l}\text { EPA Level III Ecoregion } \\
\text { (fig. 2) }\end{array}$} & \multirow{2}{*}{$\begin{array}{l}\text { No. of } \\
\text { unique } \\
\text { threat } \\
\text { types }\end{array}$} & \multicolumn{2}{|c|}{ Origin of threats data } & \multirow{2}{*}{$\begin{array}{c}\text { No. of unique } \\
\text { Level } 2 \text { Type } \\
\text { needs } \\
\text { (need types) }\end{array}$} & \multicolumn{2}{|c|}{ Origin of needs data } \\
\hline & & & & & & $\begin{array}{c}\text { ECOS } \\
\text { (April 2019) }\end{array}$ & $\begin{array}{c}\text { New or revised } \\
\text { threats data } \\
\text { (after April 2019) }\end{array}$ & & $\begin{array}{c}\text { ECOS } \\
\text { (April 2019) }\end{array}$ & $\begin{array}{l}\text { New or revised } \\
\text { needs data } \\
\text { (after April 2019) }\end{array}$ \\
\hline 1 & Alamosa & $\mathrm{CO}$ & 11,169 & Arizona/New Mexico Plateau & 8 & Yes & $\mathrm{RS}$ & 36 & Yes & RS, T, W \\
\hline 2 & Arapaho & $\mathrm{CO}$ & 23,464 & Southern Rockies & 16 & Yes & LS, T, W & 10 & Yes & C \\
\hline 3 & Baca & $\mathrm{CO}$ & 92,500 & Arizona/New Mexico Plateau & 8 & Yes & RS, W & 38 & Yes & $\mathrm{RS}, \mathrm{T}, \mathrm{W}$ \\
\hline 4 & Browns Park & $\mathrm{CO}$ & 12,150 & Wyoming Basin & 7 & Yes & $\mathrm{RS}, \mathrm{W}$ & 7 & Yes & RS, W \\
\hline 5 & Monte Vista & $\mathrm{CO}$ & 14,804 & Arizona/New Mexico Plateau & 7 & Yes & RS & 36 & Yes & $\mathrm{RS}, \mathrm{T}, \mathrm{W}$ \\
\hline 6 & Rocky Flats & $\mathrm{CO}$ & 5,237 & High Plains & 5 & Yes & LS, T & 5 & Yes & $\mathrm{C}, \mathrm{LS}, \mathrm{T}$ \\
\hline 7 & Rocky Mountain Arsenal & $\mathrm{CO}$ & 15,000 & High Plains & 6 & Yes & nc & 6 & Yes & nc \\
\hline 8 & Two Ponds & $\mathrm{CO}$ & 72 & High Plains & 8 & Yes & LS & 4 & Yes & $\mathrm{C}, \mathrm{LS}$ \\
\hline 9 & Flint Hills & $\mathrm{KS}$ & 18,463 & Central Irregular Plains ${ }^{1}$ & 7 & Yes & $\mathrm{P}, \mathrm{RS}$ & 12 & Yes & $\mathrm{nc}$ \\
\hline 10 & Kirwin & $\mathrm{KS}$ & 10,778 & Central Great Plains & 9 & Yes & $\mathrm{C}, \mathrm{P}, \mathrm{RS}$ & 3 & Yes & RS \\
\hline 11 & Marais des Cygnes & KS & 7,500 & Central Irregular Plains & 18 & Yes & LS, P & 13 & Yes & LS \\
\hline 12 & Quivira & $\mathrm{KS}$ & 22,135 & Central Great Plains & 10 & Yes & LS, T, W & 11 & Yes & LS, T, W \\
\hline 13 & Benton Lake & MT & 12,383 & Northwestern Glaciated Plains & 2 & Yes & $\mathrm{nc}$ & 5 & Yes & C, LS, RS, W \\
\hline 14 & Black Coulee $^{2}$ & MT & 1,309 & Northwestern Glaciated Plains & 3 & nd & P, RS & 1 & nd & RS \\
\hline 15 & Bowdoin & MT & 15,552 & Northwestern Glaciated Plains & 6 & Yes & C, LS, RS & 8 & Yes & LS, RS \\
\hline 16 & Charles M. Russell & MT & 1.1 million $^{3}$ & Northwestern Great Plains & 4 & Yes & C, RS & 5 & Yes & $\mathrm{C}, \mathrm{RS}$ \\
\hline 17 & Creedman Coulee ${ }^{2}$ & MT & 3,040 & Northwestern Glaciated Plains & 2 & nd & $\mathrm{C}, \mathrm{RS}$ & 1 & nd & RS \\
\hline 18 & Grass Lake² & MT & 4,318 & Northwestern Great Plains & 6 & Yes & RS & 4 & nd & $\mathrm{P}, \mathrm{RS}$ \\
\hline 19 & Hailstone $^{2}$ & MT & 920 & Northwestern Great Plains & 2 & Yes & $\mathrm{P}, \mathrm{RS}$ & 3 & Yes & $\mathrm{P}, \mathrm{RS}$ \\
\hline 20 & Hewitt Lake² & MT & 1,680 & Northwestern Glaciated Plains & 2 & nd & C, P, RS & 1 & nd & RS \\
\hline 21 & Lake Mason ${ }^{4}$ & MT & 8,813 & Northwestern Great Plains & 4 & Yes & RS & 6 & Yes & $\mathrm{RS}$ \\
\hline 22 & Lake Thibadeau² & MT & 3,868 & Northwestern Glaciated Plains & 5 & nd & $\mathrm{C}, \mathrm{RS}$ & 1 & nd & RS \\
\hline 23 & Lamesteer & MT & 800 & Northwestern Great Plains & 7 & Yes & C, LS, RS & 5 & Yes & $\mathrm{LS}, \mathrm{T}$ \\
\hline
\end{tabular}


Table 1.1. List of U.S. Fish and Wildlife Service National Wildlife Refuges in the Legacy Mountain-Prairie Region, with the number of unique threat and need types for each refuge and sources of threats and needs data.-Continued

[fig., figure; EPA, U.S. Environmental Protection Agency; No., Number; ECOS, Environmental Conservation Online System; CO, Colorado; RS, personal communication with National Wildlife Refuge staff; T, threats and needs assessment; W, Water Resources Investigation and Assessment recommendation; LS, U.S. Fish and Wildlife Service Legacy Mountain-Prairie Region Division of Water Resources staff; C, Comprehensive Conservation Plan; nc, no change; KS, Kansas; P, peer-reviewed report or journal article; MT, Montana; nd, no data; ND, North Dakota; O, on-site investigation; I, internet-published data; CAP, Containment Assessment Process or on-site investigation; NE, Nebraska; M, management plan; SD, South Dakota; WY, Wyoming; NWR, National Wildlife Refuge. Designations for origins of data are from U.S. Fish and Wildlife Service, 2017a. See Omernik (1987) for Level III Ecoregion information]

\begin{tabular}{|c|c|c|c|c|c|c|c|c|c|c|}
\hline \multirow[b]{2}{*}{$\begin{array}{c}\text { Site } \\
\text { identifier } \\
\text { (fig. 1) }\end{array}$} & \multirow[b]{2}{*}{$\begin{array}{l}\text { National Wildlife } \\
\text { Refuge }\end{array}$} & \multirow[b]{2}{*}{ State } & \multirow[b]{2}{*}{$\begin{array}{c}\text { Size } \\
\text { (acres) }\end{array}$} & \multirow[b]{2}{*}{$\begin{array}{l}\text { EPA Level III Ecoregion } \\
\text { (fig. 2) }\end{array}$} & \multirow{2}{*}{$\begin{array}{c}\text { No. of } \\
\text { unique } \\
\text { threat } \\
\text { types }\end{array}$} & \multicolumn{2}{|c|}{ Origin of threats data } & \multirow{2}{*}{$\begin{array}{l}\text { No. of unique } \\
\text { Level } 2 \text { Type } \\
\text { needs } \\
\text { (need types) }\end{array}$} & \multicolumn{2}{|c|}{ Origin of needs data } \\
\hline & & & & & & $\begin{array}{c}\text { ECOS } \\
\text { (April 2019) }\end{array}$ & $\begin{array}{c}\text { New or revised } \\
\text { threats data } \\
\text { (after April 2019) }\end{array}$ & & $\begin{array}{c}\text { ECOS } \\
\text { (April 2019) }\end{array}$ & $\begin{array}{c}\text { New or revised } \\
\text { needs data } \\
\text { (after April 2019) }\end{array}$ \\
\hline 24 & Lee Metcalf & MT & 2,800 & Middle Rockies & 16 & Yes & C, LS, T & 12 & Yes & C, LS, T \\
\hline 25 & Lost Trail & MT & 9,225 & Northern Rockies & 11 & Yes & $\mathrm{C}, \mathrm{LS}, \mathrm{T}$ & 13 & Yes & $\mathrm{C}, \mathrm{LS}, \mathrm{T}$ \\
\hline 26 & Medicine Lake & MT & 31,702 & Northwestern Glaciated Plains & 11 & Yes & LS, T & 22 & Yes & LS \\
\hline 27 & National Bison Range & MT & 18,766 & Northern Rockies & 3 & nd & $\mathrm{C}, \mathrm{RS}$ & 5 & nd & $\mathrm{C}, \mathrm{RS}, \mathrm{T}$ \\
\hline 28 & Ninepipe & MT & 4,027 & Northern Rockies & 0 & nd & nc & 1 & nd & $\mathrm{T}$ \\
\hline 29 & Pablo & MT & 2,500 & Northern Rockies & 0 & nd & $\mathrm{nc}$ & 1 & nd & $\mathrm{T}$ \\
\hline 30 & Red Rock Lakes & MT & 48,955 & Middle Rockies & 9 & Yes & LS, W & 6 & Yes & LS, W \\
\hline 31 & Swan River & MT & 1,568 & Northern Rockies & 10 & Yes & C, LS & 5 & Yes & LS \\
\hline 32 & UL Bend & MT & 560,903 & Northwestern Great Plains & 4 & Yes & $\mathrm{C}, \mathrm{RS}$ & 5 & Yes & $\mathrm{C}, \mathrm{RS}$ \\
\hline 33 & War Horse ${ }^{4}$ & MT & 3,232 & Northwestern Great Plains & 0 & nd & nc & 2 & Yes & RS \\
\hline 34 & Appert Lake5 & ND & 908 & Northwestern Glaciated Plains & 12 & Yes & RS, T & 2 & Yes & nc \\
\hline 35 & Ardoch $^{5}$ & ND & 2,696 & Lake Agassiz Plain & 1 & Yes & nc & 2 & Yes & $\mathrm{RS}, \mathrm{T}$ \\
\hline 36 & Arrowwood & ND & 2,388 & Northern Glaciated Plains & 4 & Yes & $\mathrm{RS}$ & 3 & Yes & $\mathrm{RS}, \mathrm{T}$ \\
\hline 37 & Audubon & ND & 14,739 & Northwestern Glaciated Plains & 2 & Yes & RS & 2 & nd & $\mathrm{RS}$ \\
\hline 38 & Bone Hill 5 & ND & 640 & $\begin{array}{l}\text { Northern Glaciated Plains, } \\
\text { Northwestern Glaciated Plains }\end{array}$ & 2 & Yes & $\mathrm{C}, \mathrm{RS}$ & 3 & Yes & $\mathrm{RS}$ \\
\hline 39 & Brumba $^{5}$ & ND & 1,977 & Northern Glaciated Plains & 1 & nd & RS & 1 & nd & $\mathrm{RS}$ \\
\hline 40 & Buffalo Lake 5 & ND & 1,540 & Northern Glaciated Plains & 1 & nd & $\mathrm{O}, \mathrm{RS}$ & 1 & nd & $\mathrm{RS}$ \\
\hline 41 & Camp Lake 5 & ND & 585 & Northwestern Glaciated Plains & 2 & Yes & C, I, RS & 3 & Yes & $\mathrm{RS}$ \\
\hline 42 & Canfield Lake 5 & ND & 310 & Northwestern Glaciated Plains & 2 & Yes & RS & 2 & Yes & $\mathrm{RS}$ \\
\hline 43 & Chase Lake & ND & 4,385 & Northwestern Glaciated Plains & 9 & Yes & RS & 3 & Yes & $\mathrm{RS}$ \\
\hline 44 & Cottonwood 5 & ND & 1,013 & Northern Glaciated Plains & 1 & nd & $\mathrm{O}, \mathrm{RS}$ & 1 & nd & $\mathrm{RS}$ \\
\hline 45 & Dakota Lake 5 & ND & 2,780 & Northern Glaciated Plains & 8 & Yes & $\mathrm{nc}$ & 2 & Yes & $\mathrm{nc}$ \\
\hline
\end{tabular}


Table 1.1. List of U.S. Fish and Wildlife Service National Wildlife Refuges in the Legacy Mountain-Prairie Region, with the number of unique threat and need types for each refuge and sources of threats and needs data.-Continued

[fig., figure; EPA, U.S. Environmental Protection Agency; No., Number; ECOS, Environmental Conservation Online System; CO, Colorado; RS, personal communication with National Wildlife Refuge staff; T, threats and needs assessment; W, Water Resources Investigation and Assessment recommendation; LS, U.S. Fish and Wildlife Service Legacy Mountain-Prairie Region Division of Water Resources staff; C, Comprehensive Conservation Plan; nc, no change; KS, Kansas; P, peer-reviewed report or journal article; MT, Montana; nd, no data; ND, North Dakota; O, on-site investigation; I, internet-published data; CAP, Containment Assessment Process or on-site investigation; NE, Nebraska; M, management plan; SD, South Dakota; WY, Wyoming; NWR, National Wildlife Refuge. Designations for origins of data are from U.S. Fish and Wildlife Service, 2017a. See Omernik (1987) for Level III Ecoregion information]

\begin{tabular}{|c|c|c|c|c|c|c|c|c|c|c|}
\hline \multirow[b]{2}{*}{$\begin{array}{c}\text { Site } \\
\text { identifier } \\
\text { (fig. 1) }\end{array}$} & \multirow[b]{2}{*}{$\begin{array}{c}\text { National Wildlife } \\
\text { Refuge }\end{array}$} & \multirow[b]{2}{*}{ State } & \multirow[b]{2}{*}{$\begin{array}{c}\text { Size } \\
\text { (acres) }\end{array}$} & \multirow[b]{2}{*}{$\begin{array}{l}\text { EPA Level III Ecoregion } \\
\text { (fig. 2) }\end{array}$} & \multirow{2}{*}{$\begin{array}{c}\text { No. of } \\
\text { unique } \\
\text { threat } \\
\text { types }\end{array}$} & \multicolumn{2}{|c|}{ Origin of threats data } & \multirow{2}{*}{$\begin{array}{c}\text { No. of unique } \\
\text { Level } 2 \text { Type } \\
\text { needs } \\
\text { (need types) }\end{array}$} & \multicolumn{2}{|c|}{ Origin of needs data } \\
\hline & & & & & & $\begin{array}{c}\text { ECOS } \\
\text { (April 2019) }\end{array}$ & $\begin{array}{c}\text { New or revised } \\
\text { threats data } \\
\text { (after April 2019) }\end{array}$ & & $\begin{array}{c}\text { ECOS } \\
\text { (April 2019) }\end{array}$ & $\begin{array}{l}\text { New or revised } \\
\text { needs data } \\
\text { (after April 2019) }\end{array}$ \\
\hline 46 & Des Lacs & ND & 19,500 & Northern Glaciated Plains & 5 & Yes & LS, W & 5 & Yes & LS, W \\
\hline 47 & Florence Lake 6 & ND & 1,888 & Northwestern Glaciated Plains & 4 & Yes & $\mathrm{nc}$ & 2 & Yes & $\mathrm{RS}, \mathrm{T}$ \\
\hline 48 & Half-Way Lake ${ }^{5}$ & ND & 160 & Northwestern Glaciated Plains & 0 & nd & nc & 0 & nd & $\mathrm{nc}$ \\
\hline 49 & Hiddenwood5 5 & ND & 568 & Northwestern Glaciated Plains & 2 & Yes & RS & 3 & Yes & LS, RS, T \\
\hline 50 & Hobart Lake 5 & ND & 1,831 & Northern Glaciated Plains & 3 & Yes & I, RS & 3 & Yes & RS \\
\hline 51 & Hutchinson Lake 5 & ND & 479 & Northwestern Glaciated Plains & 8 & Yes & I, RS & 1 & Yes & RS, T \\
\hline 52 & J. Clark Salyer & ND & 58,700 & Northern Glaciated Plains & 9 & Yes & $\mathrm{nc}$ & 3 & Yes & nc \\
\hline 53 & Johnson Lake 5 & ND & 2,003 & Northern Glaciated Plains & 1 & Yes & $\mathrm{RS}$ & 2 & Yes & $\mathrm{RS}, \mathrm{T}$ \\
\hline 54 & Kellys Slough & ND & 1,270 & Lake Agassiz Plain & 1 & Yes & RS & 2 & Yes & $\mathrm{I}, \mathrm{T}$ \\
\hline 55 & Lake Alice & ND & 12,096 & Northern Glaciated Plains & 5 & nd & I, P, RS & 3 & Yes & $\mathrm{T}$ \\
\hline 56 & Lake George 5 & ND & 3,090 & Northwestern Glaciated Plains & 9 & Yes & RS & 2 & Yes & RS \\
\hline 57 & Lake Ilo & ND & 4,033 & Northwestern Great Plains & 3 & Yes & I, P, RS & 3 & Yes & $\mathrm{RS}, \mathrm{T}$ \\
\hline 58 & Lake Nettie & ND & 3,055 & Northwestern Glaciated Plains & 3 & Yes & LS, RS, T & 4 & Yes & LS, RS, T \\
\hline 59 & Lake Otis 5 & ND & 320 & Northwestern Glaciated Plains & 1 & Yes & $\mathrm{nc}$ & 1 & Yes & $\mathrm{T}$ \\
\hline 60 & Lake Patricia $^{5}$ & ND & 800 & Northwestern Great Plains & 2 & Yes & $\mathrm{RS}$ & 2 & Yes & $\mathrm{T}$ \\
\hline 61 & Lake Zahl & ND & 3,823 & Northwestern Glaciated Plains & 9 & nd & $\mathrm{RS}, \mathrm{W}$ & 12 & nd & W \\
\hline 62 & Lambs Lake 5 & ND & 1,027 & Northern Glaciated Plains & 1 & Yes & RS & 3 & Yes & RS \\
\hline 63 & Little Goose 5 & ND & 288 & Northern Glaciated Plains & 1 & nd & $\mathrm{RS}$ & 1 & nd & $\mathrm{RS}$ \\
\hline 64 & Long Lake & ND & 22,300 & Northwestern Glaciated Plains & 20 & Yes & C, I, RS & 7 & Yes & RS, T \\
\hline 65 & Lords Lake 5 & ND & 1,915 & Northern Glaciated Plains & 1 & nd & $\mathrm{O}, \mathrm{RS}$ & 1 & nd & RS \\
\hline 66 & Lost Lake ${ }^{5}$ & ND & 960 & Northwestern Glaciated Plains & 0 & nd & nc & 1 & nd & $\mathrm{RS}$ \\
\hline 67 & Lostwood & ND & 27,589 & Northwestern Glaciated Plains & 9 & nd & $\mathrm{RS}, \mathrm{W}$ & 11 & nd & $\mathrm{W}$ \\
\hline 68 & Maple River 5 & ND & 712 & Northern Glaciated Plains & 3 & Yes & $\mathrm{nc}$ & 2 & Yes & $\mathrm{T}$ \\
\hline
\end{tabular}


Table 1.1. List of U.S. Fish and Wildlife Service National Wildlife Refuges in the Legacy Mountain-Prairie Region, with the number of unique threat and need types for each refuge and sources of threats and needs data.-Continued

[fig., figure; EPA, U.S. Environmental Protection Agency; No., Number; ECOS, Environmental Conservation Online System; CO, Colorado; RS, personal communication with National Wildlife Refuge staff; T, threats and needs assessment; W, Water Resources Investigation and Assessment recommendation; LS, U.S. Fish and Wildlife Service Legacy Mountain-Prairie Region Division of Water Resources staff; C, Comprehensive Conservation Plan; nc, no change; KS, Kansas; P, peer-reviewed report or journal article; MT, Montana; nd, no data; ND, North Dakota; O, on-site investigation; I, internet-published data; CAP, Containment Assessment Process or on-site investigation; NE, Nebraska; M, management plan; SD, South Dakota; WY, Wyoming; NWR, National Wildlife Refuge. Designations for origins of data are from U.S. Fish and Wildlife Service, 2017a. See Omernik (1987) for Level III Ecoregion information]

\begin{tabular}{|c|c|c|c|c|c|c|c|c|c|c|}
\hline \multirow[b]{2}{*}{$\begin{array}{c}\text { Site } \\
\text { identifier } \\
\text { (fig. 1) }\end{array}$} & \multirow[b]{2}{*}{$\begin{array}{c}\text { National Wildlife } \\
\text { Refuge }\end{array}$} & \multirow[b]{2}{*}{ State } & \multirow[b]{2}{*}{$\begin{array}{c}\text { Size } \\
\text { (acres) }\end{array}$} & \multirow[b]{2}{*}{$\begin{array}{l}\text { EPA Level III Ecoregion } \\
\text { (fig. 2) }\end{array}$} & \multirow{2}{*}{$\begin{array}{l}\text { No. of } \\
\text { unique } \\
\text { threat } \\
\text { types }\end{array}$} & \multicolumn{2}{|c|}{ Origin of threats data } & \multirow{2}{*}{$\begin{array}{c}\text { No. of unique } \\
\text { Level } 2 \text { Type } \\
\text { needs } \\
\text { (need types) }\end{array}$} & \multicolumn{2}{|c|}{ Origin of needs data } \\
\hline & & & & & & $\begin{array}{c}\text { ECOS } \\
\text { (April 2019) }\end{array}$ & $\begin{array}{l}\text { New or revised } \\
\text { threats data } \\
\text { (after April 2019) }\end{array}$ & & $\begin{array}{c}\text { ECOS } \\
\text { (April 2019) }\end{array}$ & $\begin{array}{c}\text { New or revised } \\
\text { needs data } \\
\text { (after April 2019) }\end{array}$ \\
\hline 69 & Mclean & ND & 760 & Northwestern Glaciated Plains & 1 & Yes & $\mathrm{nc}$ & 2 & Yes & $\mathrm{T}$ \\
\hline 70 & Pleasant Lake 5 & ND & 898 & Northern Glaciated Plains & 1 & Yes & $\mathrm{nc}$ & 1 & Yes & $\mathrm{RS}$ \\
\hline 71 & Pretty Rock 5 & ND & 800 & Northwestern Great Plains & 2 & Yes & $\mathrm{RS}$ & 2 & Yes & RS \\
\hline 72 & Rabb Lake 5 & ND & 261 & Northern Glaciated Plains & 1 & nd & $\mathrm{O}, \mathrm{RS}$ & 1 & nd & RS \\
\hline 73 & Rock Lake 5 & ND & 5,506 & Northern Glaciated Plains & 1 & Yes & $\mathrm{nc}$ & 1 & Yes & nc \\
\hline 74 & Rose Lake 5 & ND & 836 & Northern Glaciated Plains & 1 & Yes & $\mathrm{RS}$ & 1 & Yes & $\mathrm{RS}$ \\
\hline 75 & School Section Lake 5 & ND & 297 & Northern Glaciated Plains & 0 & nd & $\mathrm{nc}$ & 0 & nd & $\mathrm{nc}$ \\
\hline 76 & Shell Lake & ND & 1,835 & Northwestern Glaciated Plains & 9 & nd & $\mathrm{RS}, \mathrm{W}$ & 12 & nd & W \\
\hline 77 & Sheyenne Lake ${ }^{5}$ & ND & 797 & Northern Glaciated Plains & 2 & Yes & $\mathrm{C}, \mathrm{RS}$ & 2 & Yes & $\mathrm{RS}, \mathrm{T}$ \\
\hline 78 & Sibley Lake 5 & ND & 1,077 & Northern Glaciated Plains & 4 & Yes & $\mathrm{RS}, \mathrm{T}$ & 3 & Yes & RS \\
\hline 79 & Silver Lake 5 & ND & 3,348 & Northern Glaciated Plains & 1 & Yes & RS & 1 & nd & $\mathrm{T}$ \\
\hline 80 & Slade 6 & ND & 3,000 & Northwestern Glaciated Plains & 6 & Yes & RS & 3 & Yes & RS, T \\
\hline 81 & Snyder Lake 5 & ND & 1,550 & Northern Glaciated Plains & 1 & nd & RS & 1 & nd & $\mathrm{RS}$ \\
\hline 82 & Springwater 5 & ND & 640 & Northwestern Great Plains & 10 & Yes & $\mathrm{RS}, \mathrm{T}$ & 3 & Yes & $\mathrm{nc}$ \\
\hline 83 & Stewart Lake & ND & 2,230 & Northwestern Great Plains & 3 & Yes & $\mathrm{P}, \mathrm{RS}$ & 3 & Yes & RS, T \\
\hline 84 & Stoney Slough ${ }^{5}$ & ND & 880 & Northern Glaciated Plains & 3 & nd & RS & 2 & nd & RS \\
\hline 85 & Storm Lake & ND & 683 & Northern Glaciated Plains & 3 & Yes & I, RS & 1 & Yes & nc \\
\hline 86 & Stump Lake & ND & 27 & Northern Glaciated Plains & 2 & Yes & I, RS & 2 & Yes & nc \\
\hline 87 & Sunburst Lake ${ }^{5}$ & ND & 327 & Northwestern Great Plains & 9 & Yes & $\mathrm{T}$ & 2 & Yes & nc \\
\hline 88 & Tewaukon & ND & 8,343 & Northern Glaciated Plains & 11 & Yes & LS, RS, T, W & 10 & Yes & LS, P, RS, T, W \\
\hline 89 & Tomahawk 5 & ND & 440 & Northern Glaciated Plains & 4 & nd & RS & 3 & Yes & RS \\
\hline 90 & Upper Souris & ND & 32,092 & Northern Glaciated Plains & 10 & Yes & CAP, LS, T & 4 & Yes & CAP, LS, O, W \\
\hline
\end{tabular}


Table 1.1. List of U.S. Fish and Wildlife Service National Wildlife Refuges in the Legacy Mountain-Prairie Region, with the number of unique threat and need types for each refuge and sources of threats and needs data.-Continued

[fig., figure; EPA, U.S. Environmental Protection Agency; No., Number; ECOS, Environmental Conservation Online System; CO, Colorado; RS, personal communication with National Wildlife Refuge staff; T, threats and needs assessment; W, Water Resources Investigation and Assessment recommendation; LS, U.S. Fish and Wildlife Service Legacy Mountain-Prairie Region Division of Water Resources staff; C, Comprehensive Conservation Plan; nc, no change; KS, Kansas; P, peer-reviewed report or journal article; MT, Montana; nd, no data; ND, North Dakota; O, on-site investigation; I, internet-published data; CAP, Containment Assessment Process or on-site investigation; NE, Nebraska; M, management plan; SD, South Dakota; WY, Wyoming; NWR, National Wildlife Refuge. Designations for origins of data are from U.S. Fish and Wildlife Service, 2017a. See Omernik (1987) for Level III Ecoregion information]

\begin{tabular}{|c|c|c|c|c|c|c|c|c|c|c|}
\hline \multirow[b]{2}{*}{$\begin{array}{c}\text { Site } \\
\text { identifier } \\
\text { (fig. 1) }\end{array}$} & \multirow[b]{2}{*}{$\begin{array}{l}\text { National Wildlife } \\
\text { Refuge }\end{array}$} & \multirow[b]{2}{*}{ State } & \multirow[b]{2}{*}{$\begin{array}{c}\text { Size } \\
\text { (acres) }\end{array}$} & \multirow[b]{2}{*}{$\begin{array}{l}\text { EPA Level III Ecoregion } \\
\text { (fig. 2) }\end{array}$} & \multirow{2}{*}{$\begin{array}{c}\text { No. of } \\
\text { unique } \\
\text { threat } \\
\text { types }\end{array}$} & \multicolumn{2}{|c|}{ Origin of threats data } & \multirow{2}{*}{$\begin{array}{c}\text { No. of unique } \\
\text { Level } 2 \text { Type } \\
\text { needs } \\
\text { (need types) }\end{array}$} & \multicolumn{2}{|c|}{ Origin of needs data } \\
\hline & & & & & & $\begin{array}{c}\text { ECOS } \\
\text { (April 2019) }\end{array}$ & $\begin{array}{c}\text { New or revised } \\
\text { threats data } \\
\text { (after April 2019) }\end{array}$ & & $\begin{array}{c}\text { ECOS } \\
\text { (April 2019) }\end{array}$ & $\begin{array}{l}\text { New or revised } \\
\text { needs data } \\
\text { (after April 2019) }\end{array}$ \\
\hline 91 & $\begin{array}{l}\text { While Horse Hill National } \\
\text { Game Preserve }\end{array}$ & ND & 1,674 & Northern Glaciated Plains & 1 & Yes & $\mathrm{nc}$ & 2 & Yes & $\mathrm{nc}$ \\
\hline 92 & White Lake & ND & 1,040 & Northwestern Great Plains & 1 & nd & $\mathrm{RS}$ & 2 & Yes & RS, T \\
\hline 93 & Wild Rice Lake & ND & 776 & Northern Glaciated Plains & 0 & nd & nc & 1 & nd & RS \\
\hline 94 & Willow Lake 5 & ND & 2,620 & Northern Glaciated Plains & 1 & nd & $\mathrm{O}, \mathrm{RS}$ & 1 & nd & RS \\
\hline 95 & Wintering River ${ }^{5}$ & ND & 239 & Northern Glaciated Plains & 1 & nd & $\mathrm{O}, \mathrm{RS}$ & 1 & nd & $\mathrm{RS}$ \\
\hline 96 & Wood Lake 5 & ND & 280 & Northern Glaciated Plains & 1 & Yes & RS & 2 & Yes & $\mathrm{RS}$ \\
\hline 97 & Crescent Lake & $\mathrm{NE}$ & 45,849 & Nebraska Sandhills & 4 & nd & I, RS & 3 & nd & RS \\
\hline 98 & Fort Niobrara & $\mathrm{NE}$ & 19,131 & $\begin{array}{l}\text { Nebraska Sandhills, Northwestern } \\
\text { Great Plains }\end{array}$ & 2 & Yes & $\mathrm{M}, \mathrm{RS}$ & 3 & Yes & $\mathrm{M}, \mathrm{RS}, \mathrm{T}$ \\
\hline 99 & John W. and Louise Seier & $\mathrm{NE}$ & 2,400 & Nebraska Sandhills & 2 & nd & RS & 2 & nd & $\mathrm{RS}, \mathrm{T}$ \\
\hline 100 & North Platte & $\mathrm{NE}$ & 5,047 & High Plains & 2 & nd & $\mathrm{P}, \mathrm{RS}$ & 1 & nd & RS \\
\hline 101 & Valentine & $\mathrm{NE}$ & 71,516 & Nebraska Sandhills & 6 & Yes & I, RS & 4 & Yes & I, RS \\
\hline 102 & Bear Butte 5 & $\mathrm{SD}$ & 374 & Northwestern Great Plains & 0 & nd & nc & 0 & nd & nc \\
\hline 103 & Karl E. Mundt & $\mathrm{SD}$ & 1,085 & Northwestern Glaciated Plains & 5 & Yes & W & 11 & Yes & LS, W \\
\hline 104 & Lacreek & SD & 16,410 & $\begin{array}{l}\text { Nebraska Sandhills, Northwestern } \\
\text { Great Plains }\end{array}$ & 2 & Yes & $\mathrm{nc}$ & 5 & Yes & LS, W \\
\hline 105 & Lake Andes & $\mathrm{SD}$ & 5,639 & Northwestern Glaciated Plains & 9 & Yes & $\mathrm{I}, \mathrm{LS}, \mathrm{T}, \mathrm{W}$ & 28 & Yes & $\mathrm{nc}$ \\
\hline 106 & Sand Lake & SD & 21,498 & Northern Glaciated Plains & 4 & Yes & P, RS & 3 & Yes & RS, T \\
\hline 107 & Waubay & $\mathrm{SD}$ & 4,650 & Northern Glaciated Plains & 3 & Yes & nc & 3 & Yes & $\mathrm{nc}$ \\
\hline 108 & $\begin{array}{l}\text { Bear River Migratory Bird } \\
\text { Refuge }\end{array}$ & Utah & 74,000 & Central Basin and Range & 7 & Yes & nc & 39 & Yes & nc \\
\hline 109 & Fish Springs & Utah & 17,992 & Central Basin and Range & 3 & Yes & LS, W & 15 & Yes & LS, W \\
\hline 110 & Ouray & Utah & 13,846 & Colorado Plateaus & 6 & Yes & LS, W & 16 & Yes & LS, W \\
\hline
\end{tabular}


Table 1.1. List of U.S. Fish and Wildlife Service National Wildlife Refuges in the Legacy Mountain-Prairie Region, with the number of unique threat and need types for each refuge and sources of threats and needs data.-Continued

[fig., figure; EPA, U.S. Environmental Protection Agency; No., Number; ECOS, Environmental Conservation Online System; CO, Colorado; RS, personal communication with National Wildlife Refuge staff; T, threats and needs assessment; W, Water Resources Investigation and Assessment recommendation; LS, U.S. Fish and Wildlife Service Legacy Mountain-Prairie Region Division of Water Resources staff; C, Comprehensive Conservation Plan; nc, no change; KS, Kansas; P, peer-reviewed report or journal article; MT, Montana; nd, no data; ND, North Dakota; O, on-site investigation; I, internet-published data; CAP, Containment Assessment Process or on-site investigation; NE, Nebraska; M, management plan; SD, South Dakota; WY, Wyoming; NWR, National Wildlife Refuge. Designations for origins of data are from U.S. Fish and Wildlife Service, 2017a. See Omernik (1987) for Level III Ecoregion information]

\begin{tabular}{|c|c|c|c|c|c|c|c|c|c|c|}
\hline \multirow[b]{2}{*}{$\begin{array}{c}\text { Site } \\
\text { identifier } \\
\text { (fig. 1) }\end{array}$} & \multirow[b]{2}{*}{$\begin{array}{c}\text { National Wildlife } \\
\text { Refuge }\end{array}$} & \multirow[b]{2}{*}{ State } & \multirow[b]{2}{*}{$\begin{array}{c}\text { Size } \\
\text { (acres) }\end{array}$} & \multirow[b]{2}{*}{$\begin{array}{l}\text { EPA Level III Ecoregion } \\
\text { (fig. 2) }\end{array}$} & \multirow{2}{*}{$\begin{array}{c}\text { No. of } \\
\text { unique } \\
\text { threat } \\
\text { types }\end{array}$} & \multicolumn{2}{|c|}{ Origin of threats data } & \multirow{2}{*}{$\begin{array}{c}\text { No. of unique } \\
\text { Level } 2 \text { Type } \\
\text { needs } \\
\text { (need types) }\end{array}$} & \multicolumn{2}{|c|}{ Origin of needs data } \\
\hline & & & & & & $\begin{array}{c}\text { ECOS } \\
\text { (April 2019) }\end{array}$ & $\begin{array}{c}\text { New or revised } \\
\text { threats data } \\
\text { (after April 2019) }\end{array}$ & & $\begin{array}{c}\text { ECOS } \\
\text { (April 2019) }\end{array}$ & $\begin{array}{l}\text { New or revised } \\
\text { needs data } \\
\text { (after April 2019) }\end{array}$ \\
\hline 111 & Bamforth & WY & 1,166 & Wyoming Basin & 1 & nd & C, I, RS & 3 & nd & $\mathrm{C}, \mathrm{RS}$ \\
\hline 112 & Cokeville Meadows & WY & 9,259 & Wyoming Basin & 12 & nd & C, CAP, LS, P, T & 15 & nd & C, CAP, LS, RS, W \\
\hline 113 & Hutton Lake & WY & 1,968 & Wyoming Basin & 3 & Yes & $\mathrm{nc}$ & 3 & Yes & $\mathrm{C}, \mathrm{RS}$ \\
\hline 114 & Mortenson Lake & WY & 1,776 & Wyoming Basin & 5 & Yes & C, RS & 4 & Yes & C, RS, T \\
\hline 115 & National Elk Refuge & WY & 24,700 & Middle Rockies & 2 & Yes & CAP, LS, RS & 7 & Yes & C, CAP, LS, RS \\
\hline 116 & Pathfinder & WY & 16,806 & Wyoming Basin & 1 & nd & RS & 1 & nd & RS, T \\
\hline 117 & Seedskadee & WY & 27,230 & Wyoming Basin & 10 & Yes & CAP, LS, T, W & 10 & Yes & LS, T, W \\
\hline
\end{tabular}

1On figure 2, Flint Hills NWR is in the Central Irregular Plains Level III Ecoregion. The refuge Comprehensive Conservation Plan (U.S. Fish and Wildlife Service, 2000) reports that the refuge is in the Flint Hills Level III Ecoregion.

${ }^{2}$ Satellite refuge managed by Bowdoin NWR. Refuge is not staffed.

${ }^{3}$ Charles M. Russell is approximately 1.1 million acres in size, including UL Bend NWR. The UL Bend NWR is within the boundary of the Charles M. Russell NWR.

${ }^{4}$ Satellite refuge managed by Charles M. Russell NWR Complex. Refuge is not staffed.

${ }^{5}$ Limited-interest easement refuge.

${ }^{6}$ Satellite refuge managed by Long Lake NWR Complex. Refuge is not staffed. 


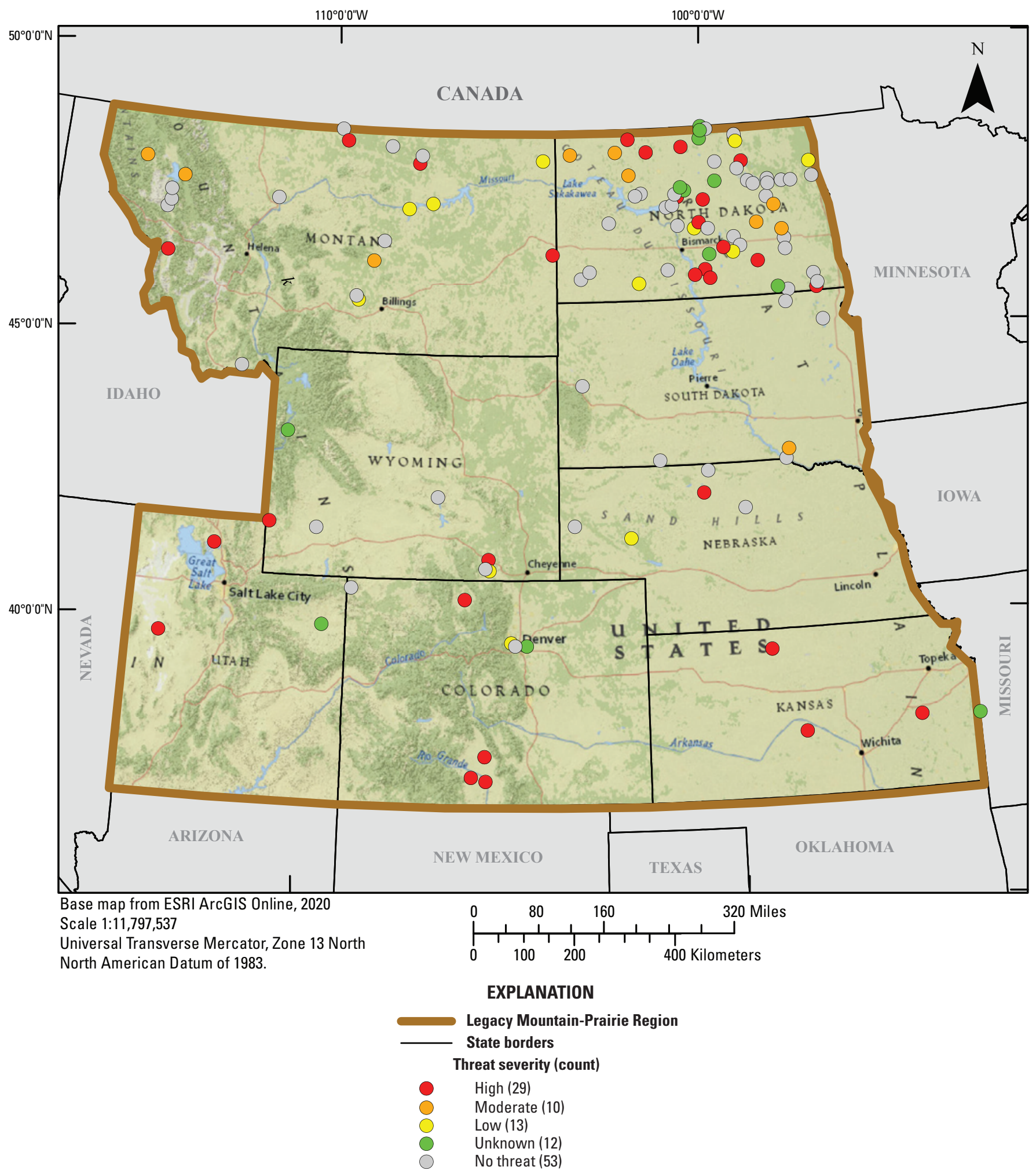

Figure 1.1. Severity rating for the compromised water management capability threat type on U.S. Fish and Wildlife Service National Wildlife Refuges in the Legacy Mountain-Prairie Region and the number of refuges with each severity rating. 


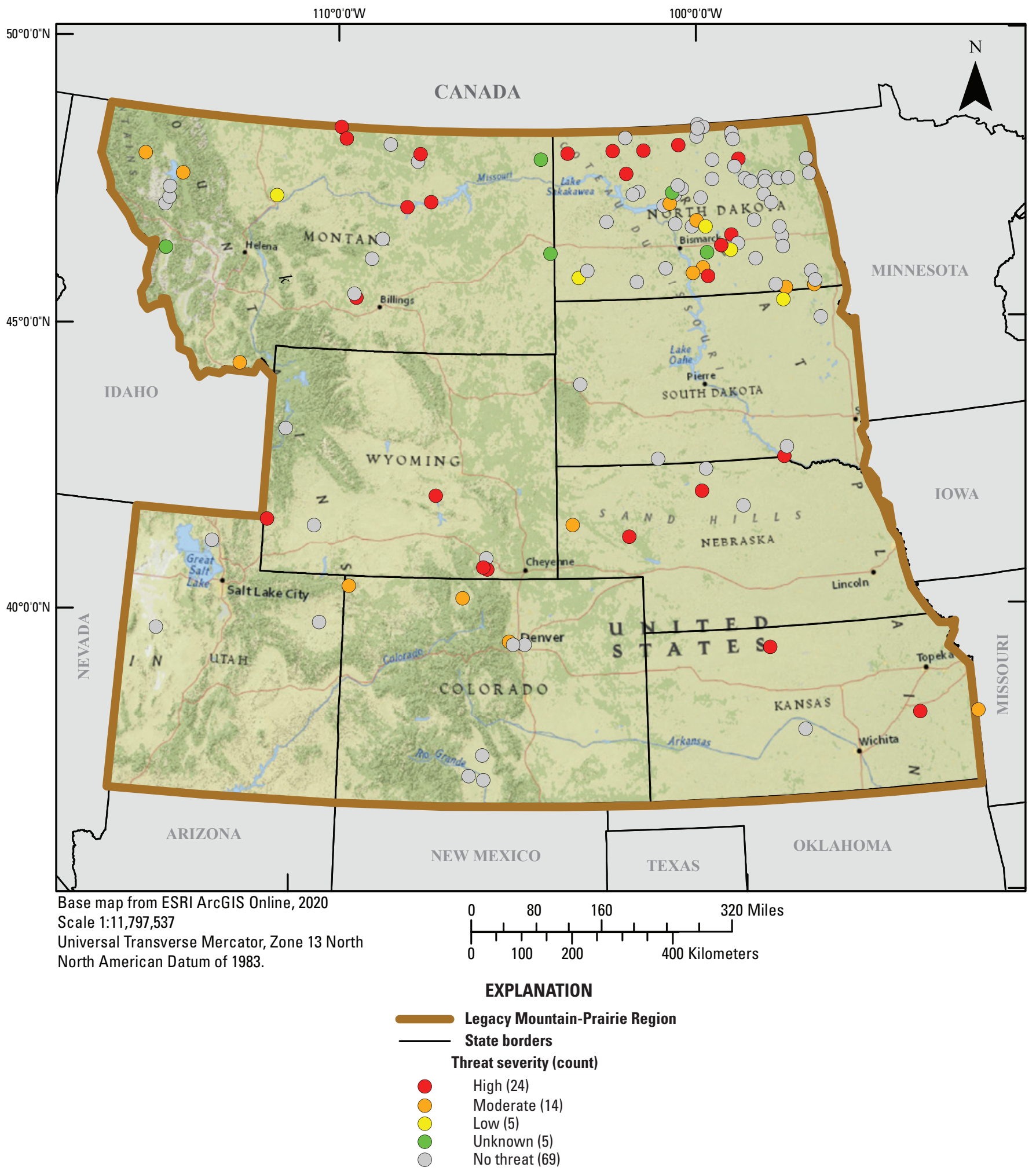

Figure 1.2. Severity rating for the habitat shifting/alteration threat type on U.S. Fish and Wildlife Service National Wildlife Refuges in the Legacy Mountain-Prairie Region and the number of refuges with each severity rating. 


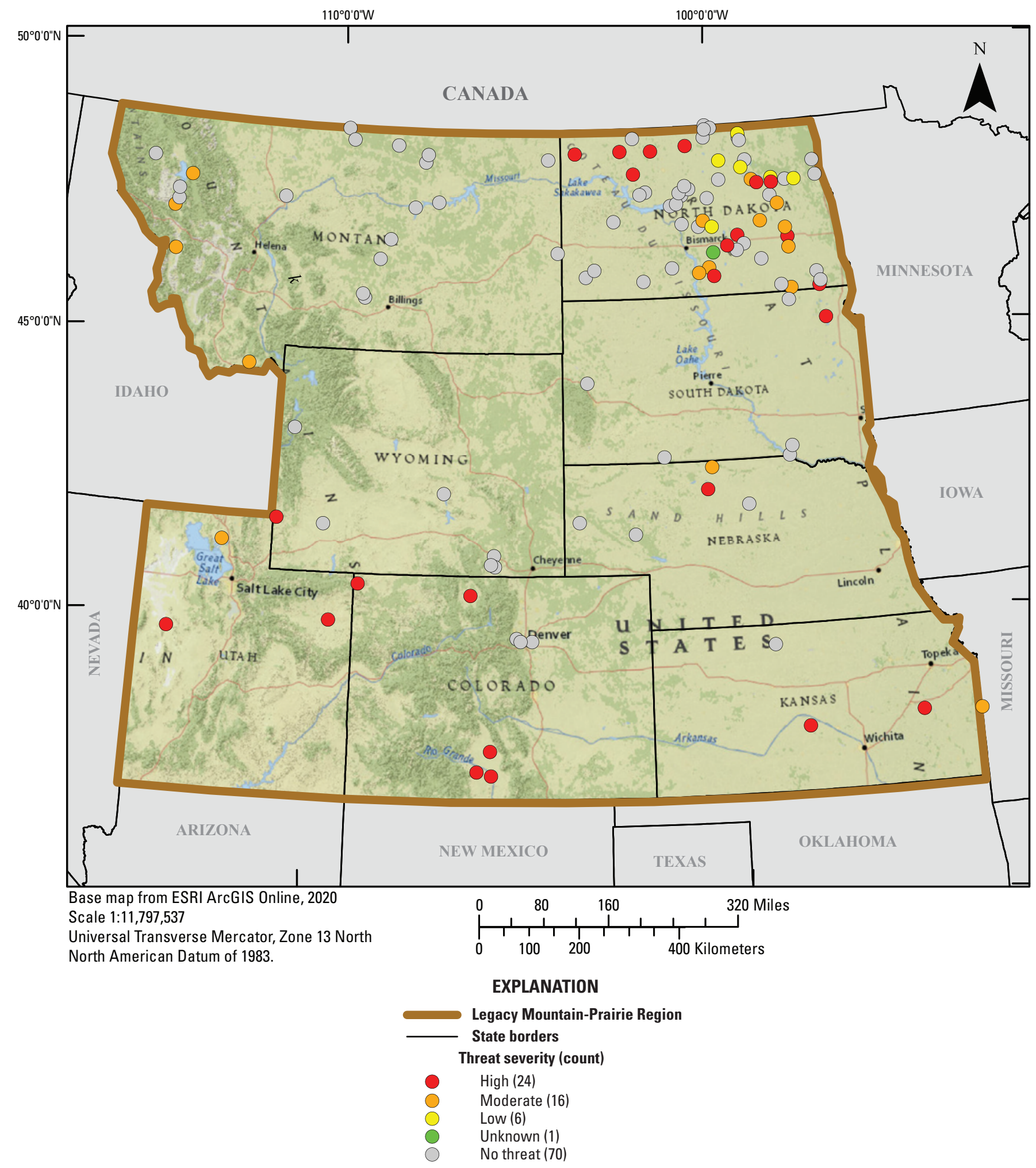

Figure 1.3. Severity rating for the altered flow regimes threat type on U.S. Fish and Wildlife Service National Wildlife Refuges in the Legacy Mountain-Prairie Region and the number of refuges with each severity rating. 


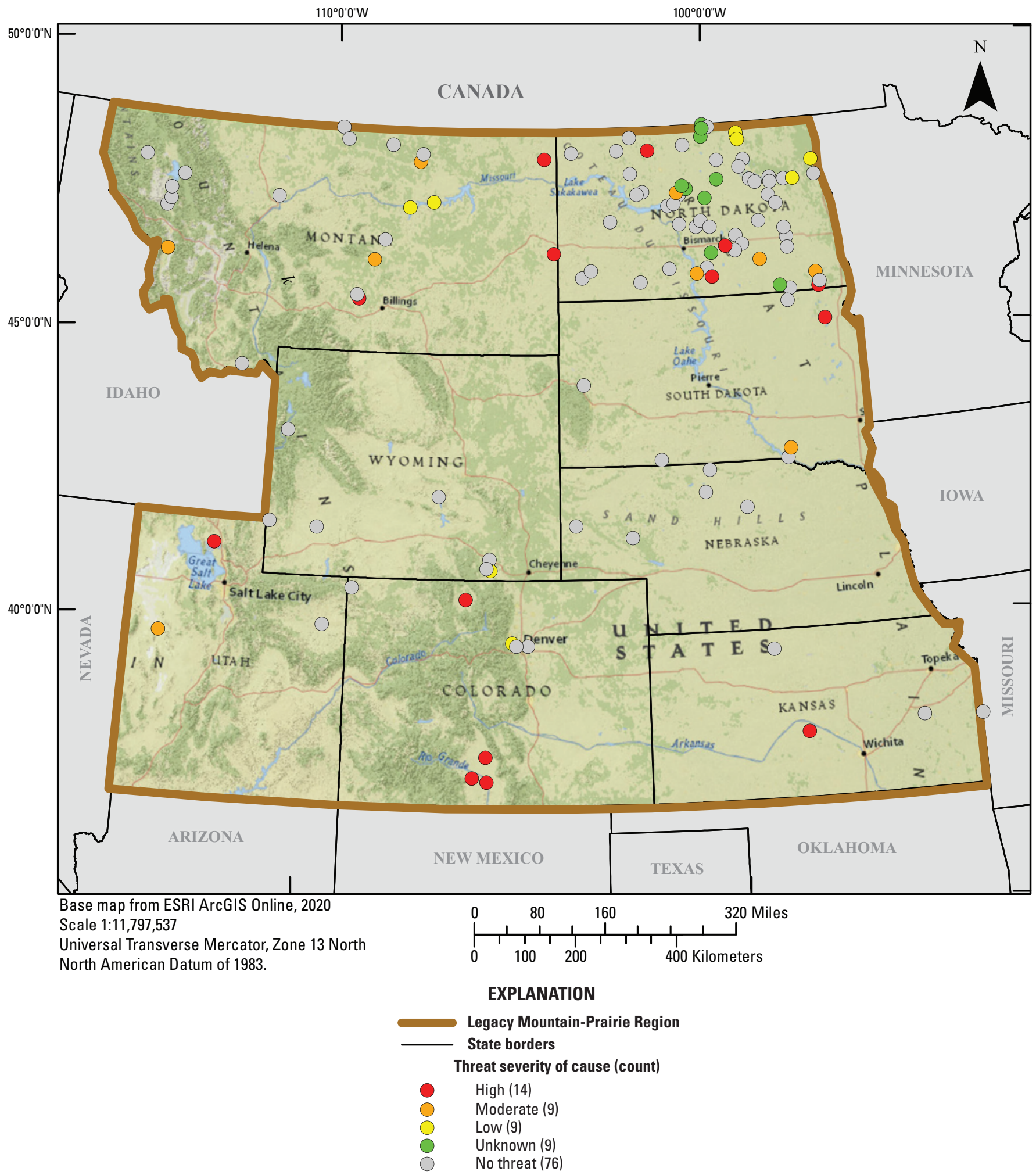

Figure 1.4. Severity rating for threats caused by inefficient, inadequate, or damaged water management infrastructure on U.S. Fish and Wildlife Service National Wildlife Refuges in the Legacy Mountain-Prairie Region and the number of refuges with each severity rating. 


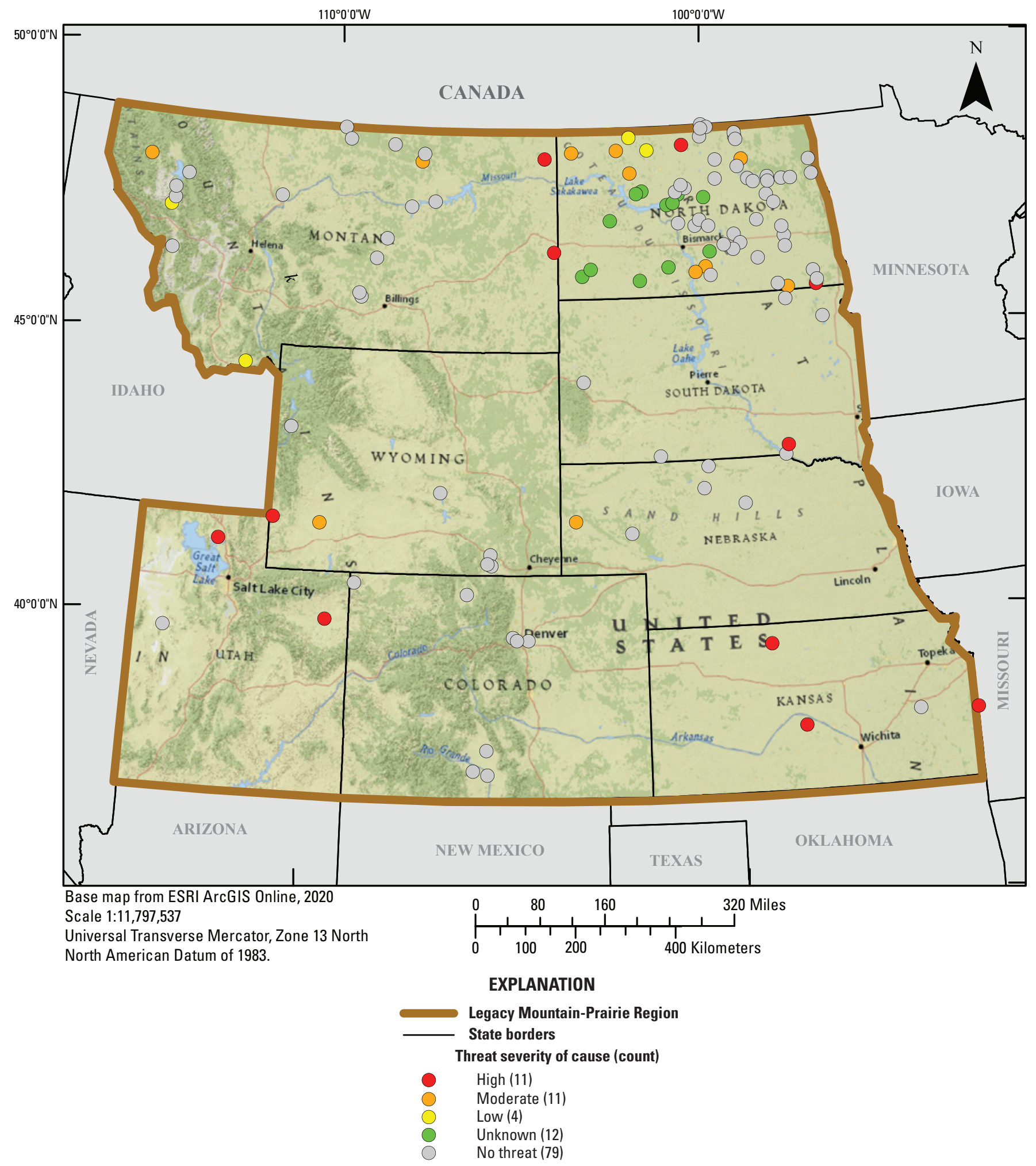

Figure 1.5. Severity rating for threats caused by agricultural runoff on U.S. Fish and Wildlife Service National Wildlife Refuges in the Legacy Mountain-Prairie Region and the number of refuges with each severity rating. 


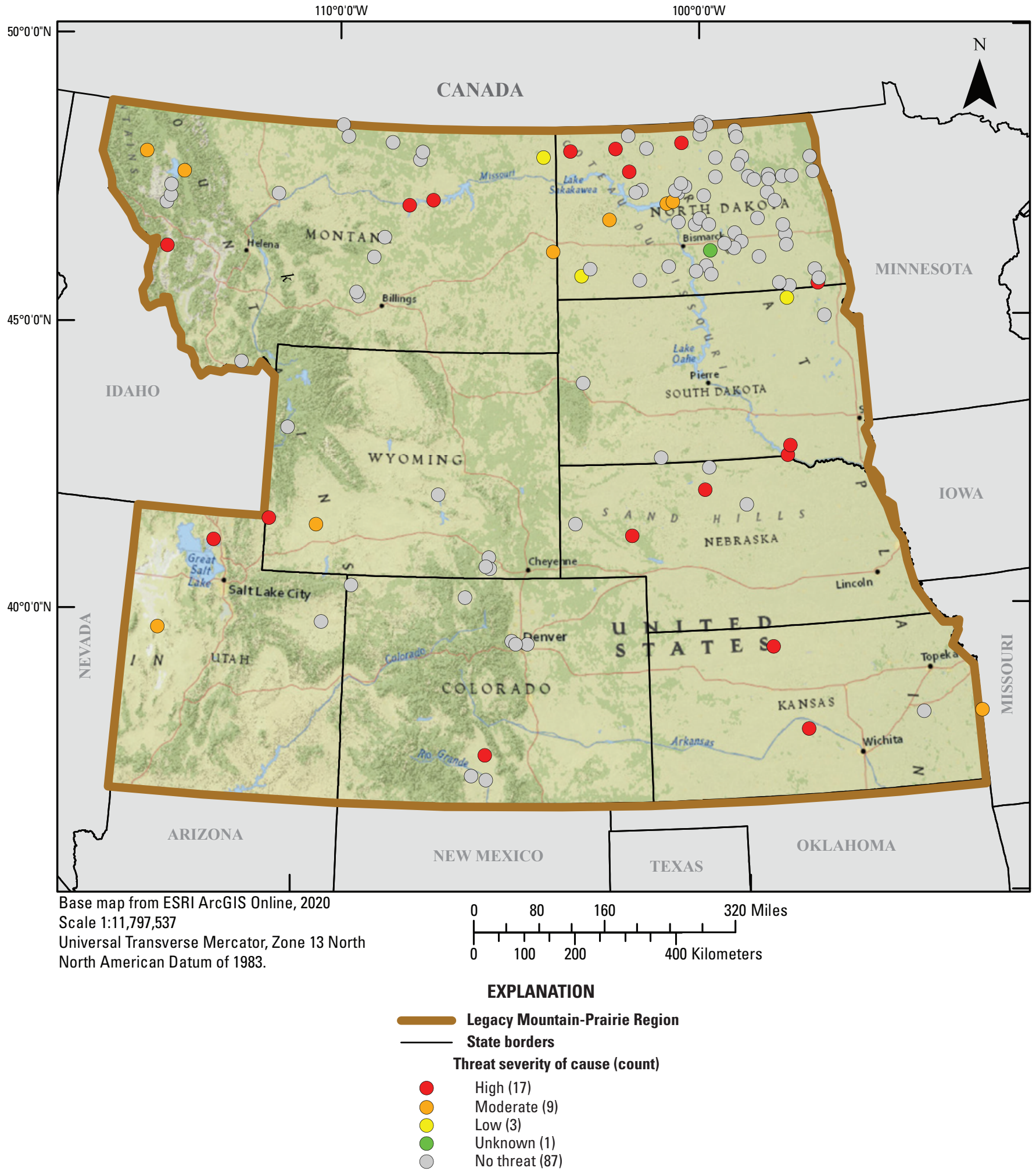

Figure 1.6. Severity rating for threats caused by the invasive species on U.S. Fish and Wildlife Service National Wildlife Refuges in the Legacy Mountain-Prairie Region and the number of refuges with each severity rating. 


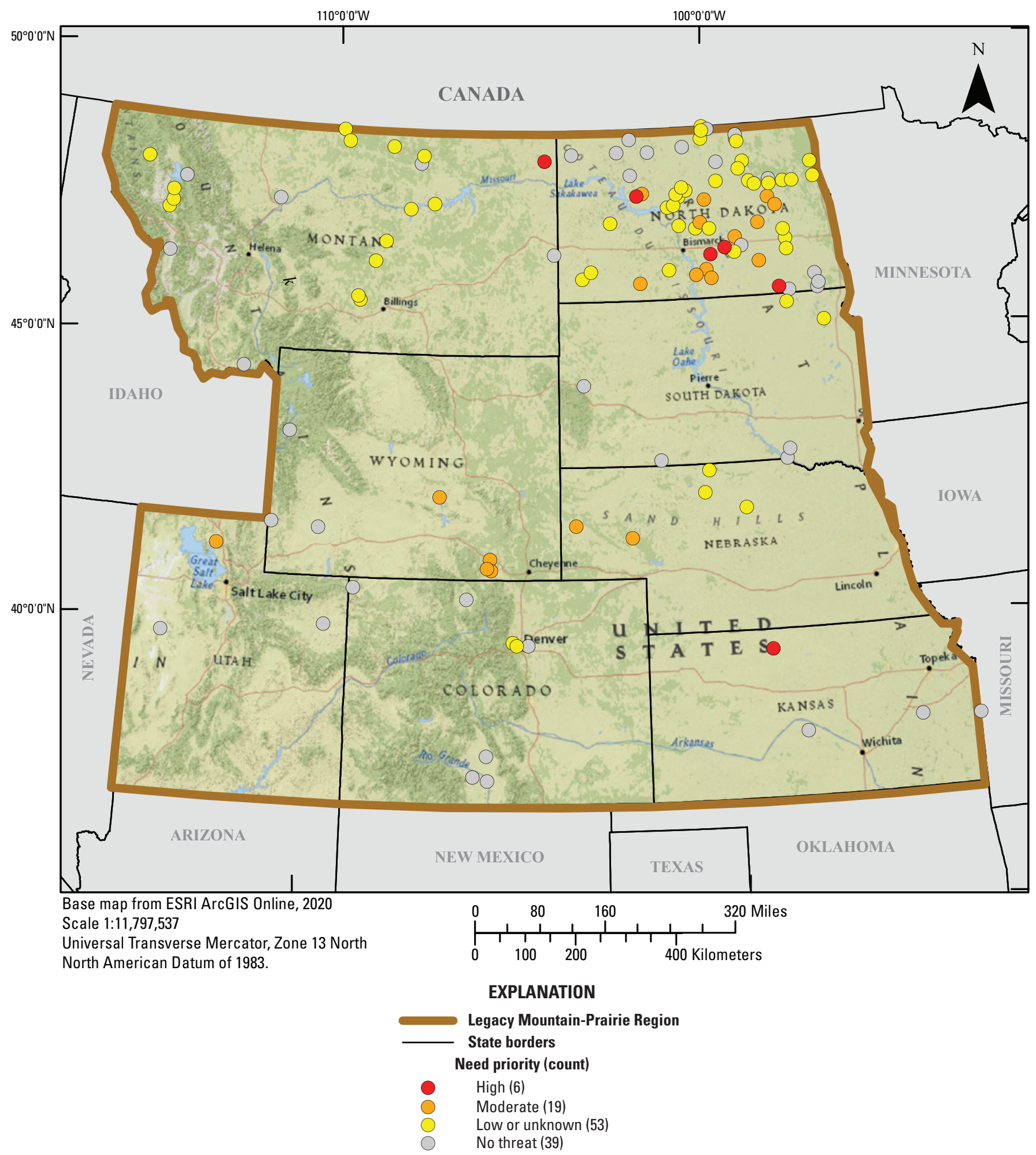

Figure 1.7. Priority rating for the Water Resource Inventory and Assessment need type on U.S. Fish and Wildlife Service National Wildlife Refuges in the Legacy Mountain-Prairie Region and the number of refuges with each priority rating. 


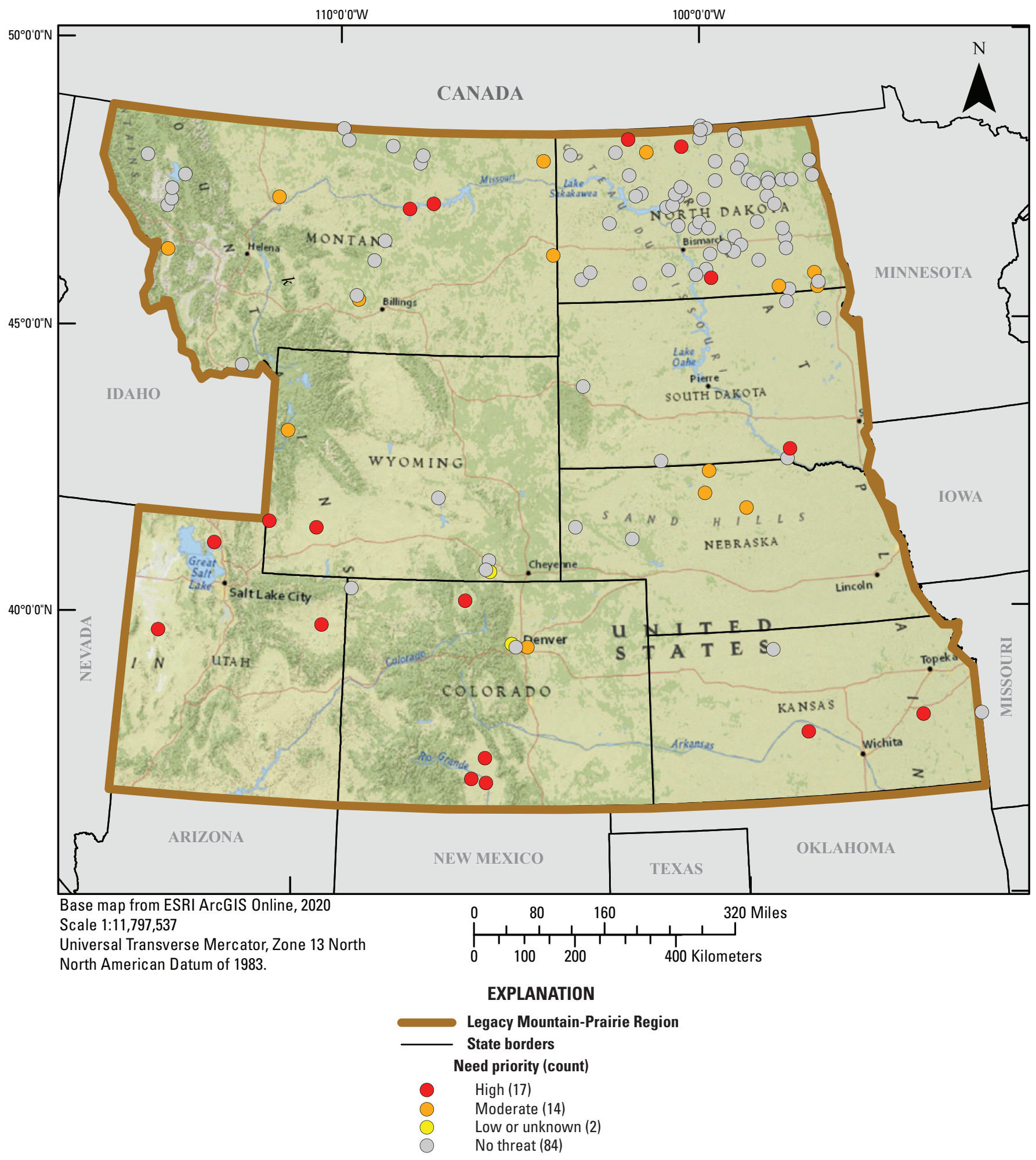

Figure 1.8. Priority rating for the repair or replace water management infrastructure need type on U.S. Fish and Wildlife Service National Wildlife Refuges in the Legacy Mountain-Prairie Region and the number of refuges with each priority rating. 


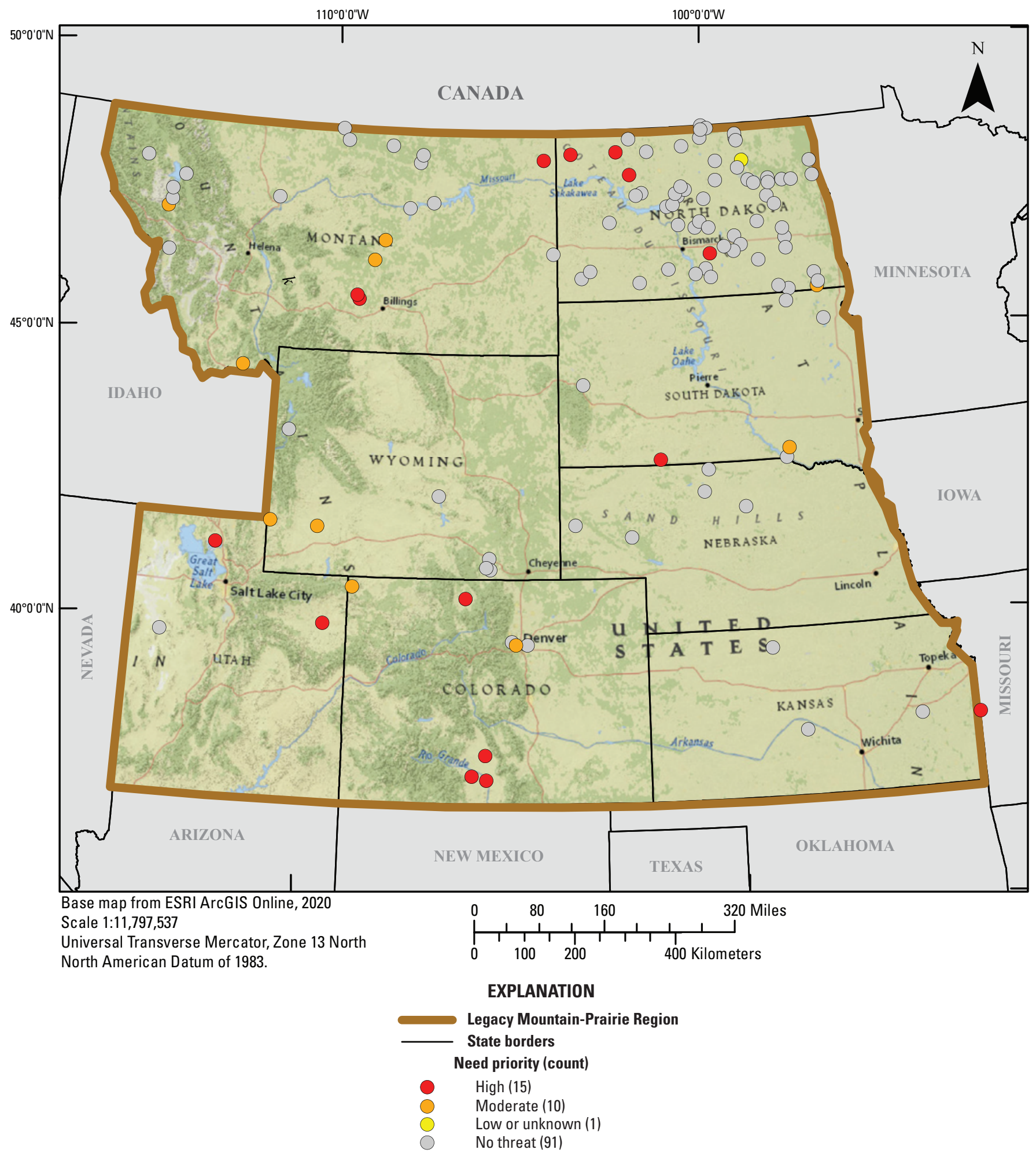

Figure 1.9. Priority rating for the water quality baseline monitoring need type on U.S. Fish and Wildlife Service National Wildlife Refuges in the Legacy Mountain-Prairie Region and the number of refuges with each priority rating. 


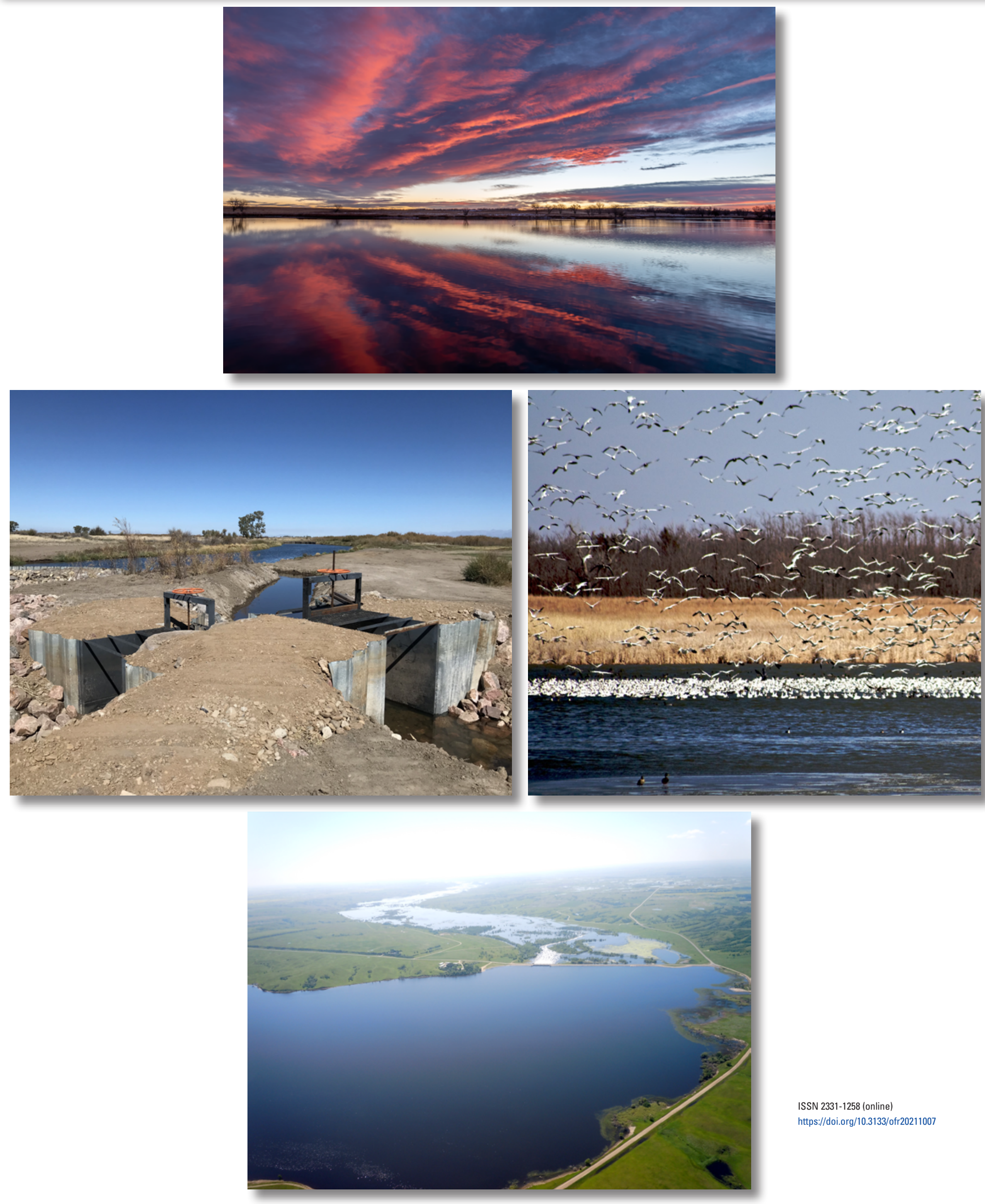

https://doi.org/10.3133/ofr20211007

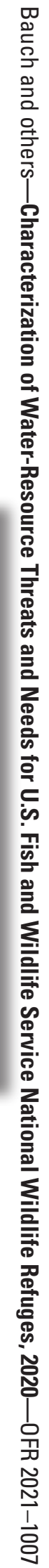

